\title{
A BIOGEOGRAPHIC STUDY OF THE HERPETOFAUNA OF EASTERN TENNESSEE
}

By

RICHARD M. JOHNSON

\begin{abstract}
A DISSERTATION PRESENTED TO THE GRADUATE COUNCIL OF THE UNIVERSTTY OF FLORIDA

IN PARTIAL FULFILLMENT OF THE REQUIREMENTS FOR THE DEGREE OF DOCTOR OF PHILOSOPHY
\end{abstract}

UNIVERSITY OF FLORIDA

June, 1958 


\section{PRRPACB}

The only extensive survey that has been made of the totel herpetofauns of the Great Swoky Hounteins region 18 thet of King (1939). This seems strange Inaswch as the Southern Appalechian Vountains have aroused the Imagination of blogeographers as posstble refugium for northern biote during Pleistocane gleciation. I believe this lack of further study of the total herpetofuane may be atcributed to et least two factors. First, the waelth of species of salamanders in eastarn Tennessee hes usurped the attention of most of the herpetologists working in this region. Second, I belleve thet herpetologists generally accapt the work of $\mathrm{KIng}$ as definitive and tend to infer from his data the composition of the herpetofaunas of contiguous arees.

Since KIng's work, numerous intensive investigations have been conducted on various elements of the herpatofauna of the Great Smoky Mountains area. As wentioned above, wost of these have been concerned with the salamanders, especially those occurring at the higher elevations. Ittla attention has been given to the herpetofauna of the mountain ranges to the north and south of the Great Smokias or to the herpetofaunas of the Valley of East Tennesees and the Cumberland Pleteau to tha west. Further, many of the existing distribution maps show the northern periphery of the ranges of "southern" amphibians and reptiles as coincident with the topographically defined physiographic province boundaries in eastern Iannessee and northern Georgla. This 
lack of Information on the total herpetofauns outeide the 1 imits of the Great Suoky Mountalns area, and lack of confidence in the validity of avallable definitions of the northern linits of ranges of southern amphiblans and reptiles, have suggested the need for a study such as the present ona.

This study has been an attenpt to deflne and show the geographlcal distribution of distinctive assemblages of amphibian and reptile apecies in a physlographically diversified area. Specifically, I have endeavored (1) to deternine Insofar as practicable the specifle and subspeciffe 1dentity of the various elenants of the herpetofaun, (2) to deternine if these various taxe exist in distinct assemblages which can be cerrelated with the mecroenvironmental factors of clinate, forest types, soll types, topographic features, and human activities, and (3) to test and propose blogeographlc hypotheses concerning the herpetofaune of esstern Tennessee. Th1s study cannot be consldered as definltive. In fact, it has proposed more probleme than it has solved. Many of these additional probleme w11 not be answered unt11 more is known of the ecology of the various animals involved and unt11 paleontological information concerning the herpetofauna of eastern Tennessee during the Plelstocene Epoch becomes avallable.

I wish to express gratitude to Dr. Archie Carr and Dr. A. K. Wallace, co-chalrmen of my Suparvisory Commitee, and Dr. Arnold B. Grobman, Dr. WLIII am J. Rlemer, and Dr. Rlchard A. Bdwards, nembers of this comaittee. I an appreclative of their assistance, encouragement, and patience during this study and during the preparation of this paper. 
I an grateful to $\mathrm{Dr}$. Walter Auffenberg, Dr. Richard Hghton, Dr. John W. Crenehaw, Jr., and to Kassrs. John J. KcCoy and C. D. W1Idar for Informative and stimulating discuselone and suggestions relative to the objectives of this study. I an especially Indebted to Rlchard Highton for the many locality records and specimens from the Great Smoky Mountalns region he supplied me and for his assistance in the fleld.

For Invaluable asststance In the fleld I an gxateful to my fanlly and to Massrs. Reaves BIngham, Fred Chester, Louls Undarwood, and Wayne Swartout. I axtend spectal thanks to Mr. Chester for hio help In tending collecting stations on hls farm, and to Nr. Underwood for assistance in the construction of collecting devices used during this study. To Mr. James Snsllshaw, Head, Hydreullc Investigetions Sect1on, Knoxville Off1ce, and to Nr. Williams, Head, Hydraulic Data Branch, Chattanooge Office, Tennessee Valley Author1ty, I am grataful for climatological data generotioly supplied by thotr respective offices. Last, but not least, I wish to thenk Dr. Lakoy A. Martin, Rresident, Tennessee Wasleyan College, for the encouragenent and help that: ande it possible for we to carry out th1s study. 
TABLE OF CONTENIS

PRERAGE ........................

LIST OR TABLS .................... v vi

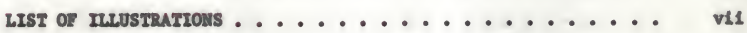

1. INTRODUCTION ................. 1

II. TIB STUDY ARE ...................... 6

A. Physelography ................. 6

8. Solls .......................... 13

C. Dralnage ...................... 14

D. Clinate ........................ 19

E. Vegetation ..................... 23

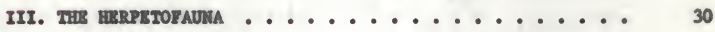

A. Cless Anphibla ............... 30

B. Class Rept111. .................. 81

IV. Drscussron ................... 163

A. Herpetof sunal Assemblages .......... 263

B. Environmental Factors and the Herpetofauna . . . . 183

C. Blogeography ................ 197

v. suRrarT ................... 220

vI. IITRRATURB CITED .................... 214

BIOGRAPHTAL SKRTCH ................... 221 


\section{LIST OF TABLES}

Table

Page

1. Intraneous, Bxtraneous, and Bndemic Elements of the Herpetofauna ....................

2. Distribution of the Intraneous and Endente Blements...

3. Distribution of the Extraneous slanente ......... 


\section{LIST OP ILLUSTRATIONS}

1. Locations of weather stations from which data were obtalned to construct $\mathbf{1 \text { gures }} 4$ and 5 .........

2. The physiographic provinces, political subdivisions, and principal rivers and streams of eastern Tennessee . .

3. General so11s types of eastern Tennessee ........

4. Waraing curves and precipitation from January through July ......................

5. Cooling curves and precipitation from July through January .......................

6. Forest regions of eastern Tennessee ...........

7. Localities for the Hellbender, Cryptobranchus allegan1ensis, the Waterdog, Necturus maculoous, and the Redspotted Newt, Dienictylus v. viridescens .......

8. Localities for the Spotted Salanander, Ambystoma maculatum, the Marbled Salanander, $A$. opacum, and the Bastern IIger salamander, A. ‥ tigrinum ........

9. Localitles for the subapecies of Jordan's Salanander, Plethodon jordanl, Weller's Salamander, $\underline{P}$. veller1, and the axea In which the Yonahlossee SaImander, $\underline{P}$. yonahlossee, is reported to occur ...........

10. Localitles for the Red-backed Salamander, Plethodon $\mathrm{C}$. clnereus, the 218 zag Salanender, B. d. dorsalle, and the S11ny Salanander, R. R. glutiñosur

11. Localities for the Four-toed salamander, Hemidactyllum ecutatum, the Spring Salamander, Gyrinophilus porphyr 1tlcus, the Mountaln Spring Salamander, G. danlele1, and the Tennessee Cave Salamender, G. palleucus ......

12. Localities for the Midland Salamander, Pseudotriton . diastictus, and the subspecies of the Rad Salamander, P. rubar .....................

13. Localities for the Green Salamander, Anaides seneus, and the subspecies of the Two-11ned salamander, Furycea bislineate .................. 
14. Localities for the subspecies of the Long-talled Salamander, Burycea longlcauds, and the Cave Salamander,

. Iuclfuge ..................

15. Locallties for the Bastern Spadefoot Toad, Scaphlopus h. holbrook1, the Amarican Toad, Bufo t. emericanus, and Fowler's Toad, B. y. fowler1 ..........

16. Locallties for the Morthern Crlcket Frog, Acris \&. crep1tans, the Morthern Spring Peeper, Hyle c. crucifer, and the Bastern Gray Treefrog, H. v. verslcolor. ......

17. Localities for the Chorus Irog, Pseudacr 1s nigrits, the Hountain Chorus Frog, P. brachyphons, and the Bastern Marrowmouthed Toad, Merohyle c. carolinensis .....

18. Localities for the Bullfrog, Rana catesbiang and the Green Frog, ‥ ‥ melanota . . . . . . . . . .

19. Localities for the Wood Frog, Rana gylvat1cs, the Leopard Frog, I. plplens, and the Pickerel Frog, ‥ palustris ...................

20. Locallties for the Common Snapping Turtle, Chelydra s. serpentina, the stinkpot, Sternotherus odoretus, the Stripennecked Turt1e, S. ‥ peltifer, and the Eastern Hud Turtle, Kinosternon . subrubrun .........

21. Localit1es for the Bestern Box Turtle, Terrapene c. carolina, and the Rastern Splny Softshell, Irlonyx $\mathrm{f}$. spinifera .....................

22. Locallties for the Map Turtle, Graptemys geographlca, the Ouachita Mep Turtle, G. R. ouachitensis, and the Painted Turtle, Chrysenrs plcte...........

23. Locallt1es for the Cooter, Pseuderys floridana, and the subspectes of the Pond slider, $\underline{\text {. }}$ ecripta . . . . . .

24. Localities for the Carolina Anole, Anolis c. carollnensis, and the Northern Fence Lizard, Sceloporus u. hyecinthinus .....................

25. Localitles for the Eastern Siender Gless Lizard, Ophtsaurus a. longlcaudus, and the \$1x-11ned Racerunner, Cremidophorus sexilneatus .............. 
26. Localities for the Ground Sk1nk, Lygosoma Interale, and the Coal skink, Eumeces anthracinus ........

27. Local1tias for the Fiva-11ned 5kink, Fumeces fasclatus, the Broad-headed skink, E. 1at1ceps, and tha Southeastern F1ve-11ned skink, E. Inexpectatus ...........

28. Local1t1es for the Queen Snake, Natr 1x septemvittats, and the Conmon Water Snake, N. Blpedon.......

29. Local1ties for the Brown snake, storerla dekayl, and the Horthern Red-bellied Snake, S. o. ocefpitomaculata .

30. Localities for the Bastern Garter Snake, Thamnoph1s s. sirtal1s, the Bastern Earth Saaka, Haldea y. valer1ae, and the Eactern Bognose Snake, Heterodon R. platyrhinos .....................

31. Localities for the Eastern RIngneck Snaka, Dladoph1s punctatùs .....................

32. Local1t1es for the Worm Snake, Carphophis amoenus ... .

33. Localities for the Racar, Coluber constrictor, and the Bestern Rough Green Snake, Opheodrys a. sestivue ....

34. Locallese for the Corn Snake, Blaphe 8. guttate, and the Rat Snake, E. obsoleta ..............

35. Localities for the Northern P1ne Snake, Pltuophis 도. melenoleucus, the Scarlet snaks, Cemophora cocclnea, and the Growned snake, Tantilla coronata......

36. Localities for the Mole Snake, Lampropeltis c. rhombomaculata, subspecias of the Common Ringsnake, L. getuIus, tha Scarlat Kingenaka, L. d. dollats, and the Eastern Mlk Snake, I. d. tríngulum .........

37. Localities for the Northera Copperhead, Ancistrodon c. mokeson, and the Iimber Rattlesnake, Crotalus $\mathrm{h}$. horridus .......................

38. Herpetofaunal areas of eastern Tennasses ........ 


\section{INTRODUCTIOs}

The herpetological material upon which this study is based is that which I have collected. Terrestrial forms were taken by the ucual methods of turntang loge, rocks, boards, and brush as well as by searchIng out those foraglag In the open. Aquatic forms vere collected with selne, hook-and-1ine, traps, and by owtmaing with a face mask. The last mathod was possible only in the mountain rivers and etreans whera clear vater is found. Practically all of the opecinens collected and exanined during the course of thls study have been deposited in the Univerelty of Floride Collections.

This study was not primarily taxonoalc in nature, and relative1y fow comperative series of specinens were exmmined. Such serias as were ut1lized were obtalned froe the University of Florida Collections. If the procedure had been followed of conparing all my specinans with topotypic material of the same species, the revilionary work involved would have diverted unreasonable anounts of tine fron the maln objactive of this study. The majority of gy specinens have been idantified by the use of existing 11terature and refarances. The origins of nemes are given in the text. In those Instances where I was dissatisfied wth o I1terature Ident1fication, I ut1lized comparative ser1es. Bven so, I vas occastonally unable to arrive at a satisfactory 1dentiflcetion. Instead of attempting to find new charactere or to rafine the exioting cheracters-mhich procedure would have taken me too far afleld 
for the scope of thls work- I have Indicated the status of such series as questonable. These specteens have not been ut1lized in the blogeographic aniyste, or have been used with qualifyins etatements appended. Specimene of three geners of salamanders and one species of snake vere collected by we but referred to othere for Indentiflcation. All spectmens of the gemus Plethodon (Moodland salamandere) which I collected were glven to Rlchard Highton and the specles and subspectee of this genus which are reported so occurring in eactern Tennessee are Ineluded on the besis of his monographle study of thls genus (Blghton, MS). The genara Desmognathue (Dusky Salamanders) and Laurognathue (Shovel-nosed salamanders) were onltted from thls etudy. A brief statemant 18 given concerning which opecies of these two generalare reported as occurring in eastern Tennessee (VIde page 39). All of ay specimens of the genus Haldea (Rarth 8nakes) were given to Mas Loulse D. 21118, who is engaged in a review of this genus.

The general texonomic arrengement is that of schmidt (1953). The coumon names used in the text are taken from Conant, at al. (1956). Locallties and elevations at whlch the specinens were collected ware determined from topographle maps avallable fron the Tennessee Valley Authorlty. The maps used were the following: Tonnessee-North Carolina Quadrangle, 15 Mnute SerLes; Tennesee-Worth Carolina law Knob Quadrange; Johnson CIty, Sheet IIJ 17-10, Ser1es V501; Knoxville, WI 17-1, AMS Ser1es V501; Chattanooga, II 16-3, AMs Serles V501; Rome, WI 16-6, AMs Ser1ee v501; Great Smoky Mountalns Mational Park and Vie1nity, Edition of 1950, m3515-W 8300/35,5267.5 
The distribution maps indicate localities frow which I have personally collected specimens and localities reported in the literature. On theee maps the localities from which I have taken specimens are Indicated by solld symbols; 11terature records are Indicated by hollow gymbols.

Thornthwalte (1948) presented a complicated systea for classifylng climate based upon man annual, monthly and seasonal temperature, ralnfall, and calculated runoff and evaporation. Shanks (1954) found good agreement between climate calculated by this mathod and the distribution of the spruce-fir forests of the high altitudes in the Great Senoky Mountains. Daubenatre (1956), on the other hand, was unable to find distinctness of climate among the belts of natural vegetation in castern Washington and northern Idaho when the climate of these reglons was calculated by the Thornthwalte 1948 systen. Early In this study I used the Thornthwalte systen to analyse the climatic date of castarn Tennessee. ThIs system was abandoned whon I was unsble to obtain correlation between the resulting climatic areas and the distributions of the forest regions and solls groups. For exrample, elimatie designation of the Cumberland Mountains region, where alxed mesophytic forest 18 climax, was the same as the climatic designation of the southern and of Valley where oak and hlekory forests are cllmax. Daubennire (loc. c1t.) did find climatic distinctness among belts of natural vagetation in his study axes by plotting elimographs of mean monthly temperature and the median sonthly rainfall. Although somewhat modified, I have used Daubenulrets method in presenting climatic data for study area (Figs. 4 and 5 ). 
The date utilized In an appraisal of the climate were furnished by the Tenaessee Valley Author1ty. The weather stations selected are shown in Figure 1. Crossville, elevation 1,862 feet, repreaents the Cuberland Plateau; Knoxville, elevation 950 feet, Mewport, elevation 1,096 feet, and Rogereville, elevation 1,375 feet, represent the northern segnent of the Valley Province; Decatur, elevation 800 feet, and Chattanooga, elevation 670 feet, represent the southern segment of the Valley Province; Gatlinburg, elevation 1,460 feet, represents the lower slopes of the Dnake Mountalns Province. The data for the northern segment of the Valley are mean values of the combined date from Knoxville, Nemport, and Rogeroville. The data for the southern segnent of the Valley are mean values of the combined data from Decatur and Chattanooga. 


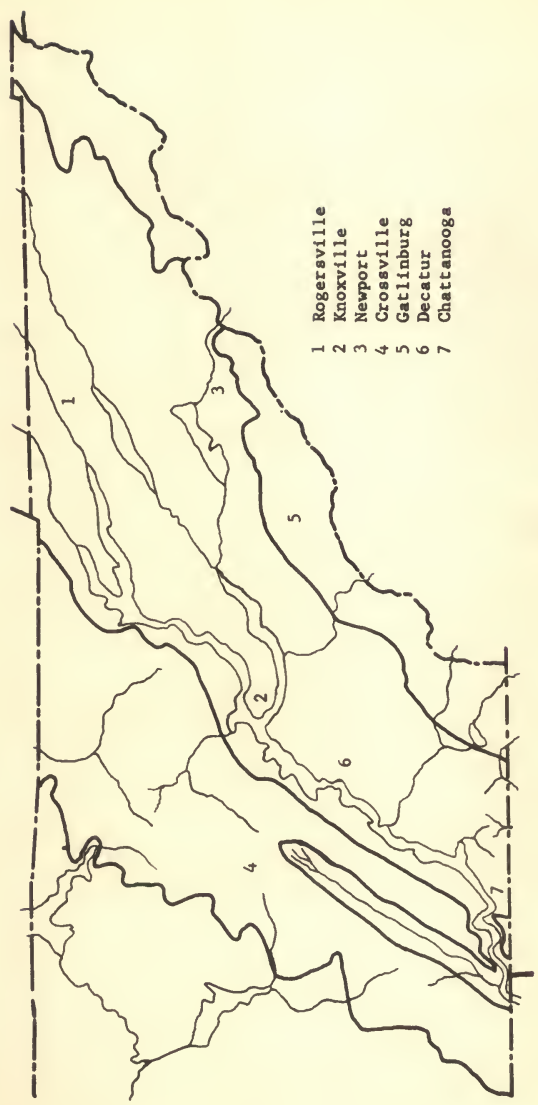

ن 


\section{THS STUDX AREA}

\section{A. Physalography}

The aree called castern Tennessee is not Identical with the politicel subdivialon "Zast Iennessee." The latter Is only that portion of the state east of the westarn boundarles of Scott, Marion, and Intervening count1es (Rodgers, 1953: 3). As used in this study, eastern Tennessee 1 the aree frow the vestern escarpant of the Cumberland Plateau eastward to the surante of the Unaka Nountains (F1g, 2). The total area Involved 1s approximately 14,700 square miles (Iueble, et 르., 1939: 6-8).

There are three physlographlc provinces in ceatern Tannessee. Except es noted, the following descriptions of these provinces are sumarized from Lubble, et 르. (10c.c1t.) and Rodgers (op. c1t.).

The Cumberland Plateau Province comprises epproximately 4,500 square mlles of the study area. At the northern boundary, the Plateau Is about 70 mlles wide; the wdth of the southern boundary is about 50 miles. For the most part, the surface of the Plateau is undulsting and submaturely disected, with the ateepness and depth of the valleys Increesing toward the edges (Penneman, 1938: 377). A characterietic feature of much of the Pleteau 18 the entrenchment of many of the mafor streans to dopthe of as wuch as 200 to 300 feet below the surface of the Plateau. The resultant gorges heve nearly vertical valle and my be quarter of a mle in width. These features have reoulted in the naming of this aree the Cliff Section of the Plateau (Breun, 1950:97-98). 


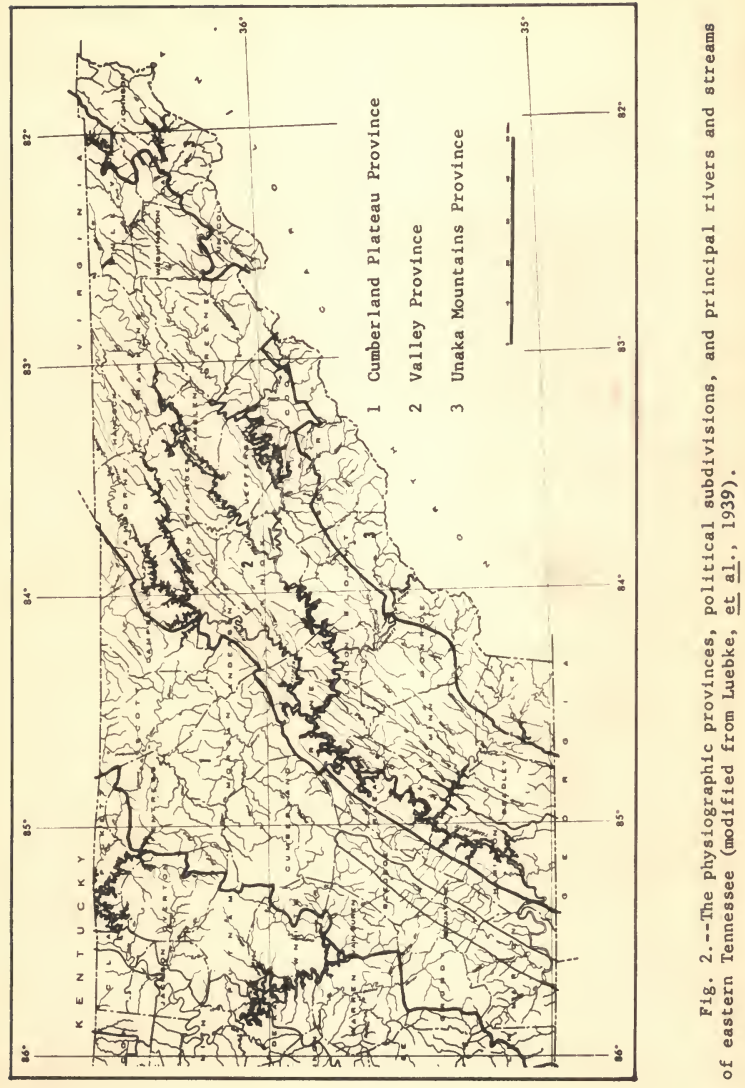


From the Emery River hortheestward to the Virginla 11ne, the sastern front of the Pleteav is separated from the main body of the tableland by a valley or line of vaileys. This is the Curberland Kountain Section of the Platesu (Fenneanan, 1938: 329). This area is strongly dissected and contains some of the most zugged mountains of eastern Tennessee. Here, too, are the highest elevations of the Plateau. Some of the mounteln summits and wetershed divides are more than 3,000 feet In elevation. Most of the surface of the main body of the Plateau is at an elevation of 2,000 fast. The southern end of the Plateau, Iike the Cumberland Hountain Section, is in - mora edvanced stage of disection then is the cantral portion. Ho flat uplend occurs in the southernmost 30 or 40 miles (Fanneman, 1938: 338). The western frout of the Pleteau 18 quite ragged, whth long opurs jutting out into the Highland Rim Provinee. Between these spurs are doep coves and valleys locally termed "gulfs." In contrast is the relatively emooth, straight edge of the eastarn front, whlch for wuch of its langth is a sheer eliff rising 1,000 feet above the Valley of Iast Tannessee. The entire castarn front, from the Ionnesece RIver on the south to Cove Greek valley in Cempoll County on the north, is known as Walden Rldge. In the middle of the southern half of the Plateau is the Sequatchie Valley, an enticline approximataly $8 i x$ milas wide and 60 miles 10ng. It is entrenched 1,000 faet below the surfece of the Plateau. The surface of the Plateau is underlain by the Welden and Lookout sandstones of Pennoylvanian age. Beneath these is Bangor limestone of Mississipplan aga, which forms the floor of the larger valleys ouch 
as Sequatchle Valley. The steepness of the cliffs In the Cliff section and of the eastern and vestern escarpments 18 due to the sapping of these sandstones and limestone.

To the east of the Cumberland Plateau is that portion of the Ridge and Valley Province of Fenneman (1938: 195) locally known as the Valley of Iast Tannessee. It is the largest of the physlographic provinces in eastern Tennessee. It varies from 45 to 70 miles wide, with the greatest width occurring in the northern part, and is approxinately 8,000 square miles in area. Rldges constitute less of the total ares than do vallays (Fonneman, 1938: 265). However, there is little flat surface, most of it befing dissected Into valleys between ridges and knobs of varying elevations. The most level surfaces of the Valley floor oceur In narrow strips five to six atles wide along the Tennessee and Ilwassee rivers (Fennenan, 1938: 271-272). Th1s flat surface is about 800 feet in elevation and represents northern extensions of the Coosa peneplafn more extensively developed In Alabam and Georgia. Safford described five types of ridges in the valley (quoted in Rodgers, 1953: 14-16). The differences anong these types of ridges 1s the reeult of differences in 1ithology, which also has resulted in differences of natural fertility of the soll. These differences in natural soll fertility are reflected in differences of prevalling vegetation on the ridges. Thus, ridges with solls derived from sandstones have (had) forests composed principally of oaks and chestnut.

The valleys between the ridges do not lend themselves to ganeralleed characterizations. Some are nerrow and overlooked by mountains. 
Others are sandrlched between a mountain and a covby ridge and have consistently barren acid solle derived fron noncaleareous shales. Still others, often on the opposite side of a mountain from the above type, are fertile and rich.

Inliers of the Valley occur in the westera portion of the mountaln provinee, especially in the Swoky Hountalns range. These are relatively flat-floored limeatone valieys ranging from five to ten square anles in area and from 1,200 to 1,800 feet in elevation (Penneman, 1938: 175). Surrounding then are mountains several thousands of feet higher. The surfaces of the coves (Inliers) are presumed to represent Hartisburg poneplain aurfaces. Among the better known of these coves are Wear, Cedes, and Tuckaleechee.

Bordering the eastern margin of the Valley is the Unake Mountains Province of castern Tenaessee. (Terminology is that of Reith, Message from the President . . .," 1902: 114). The mountalns of this province are the western front, in part, of the southern section of the Blue Ridge Provlnce of Pennemen (1938; 173-174). This Unaka ProvInce ranges from two to 20 miles in width and embraces an ares of approximately 2,200 equare alles. The mountsins are a series of from two to five parallel ridges. The main axis is the most easterly one and for mech of its length this straddles the Tennessee-llorth Carolins state 1ine. Several names are applied to various segments of the main exis. Beginning in the southwest and proceeding northeastvard these segments are: (1) the Dnaka (Frog) Mountalns, froe Georgia to the Litle Tennessee River, (2) the Great Swokg Mountalns, from the Little 
Tenneseee River to the French Broed River, (3) the Bald Mountains, from the French Broad River to the Nollchucicy River, (4) the Unaka Mountains, from the Nollchucky River to the Watauga River, (5) the Iron Mountalns, fron the Watauga River into Virginia (Raith, In Wlesage from the Prealdent ..." 1902: P1. IV). The meximum elevations of the Unaks Prov* Ince, Including some of the highest peaks in Eastern United states, are to be found In the Great Snoky Mountains. From these maximum elevat1ons (In ercess of 6,000 feet) In the Smoky Mountalns, the thairas have progresstvely lower sumatts in all directions. The westernmost edge of this province south of the French Broad River is prominently delintted by a ceries of outlying 1solated mountalne arranged in a 11near series. These include (from southwest to northeast) starr, Chllhowee, and Bnglish mountalns. The lovest of these is Starx Mountain whth an elevation of about 2,500 feet. The highest is Englioh Nountaln with a meximum elevation near 3,600 feet. The entire serles is named the Chilhowee Range, after Chilhowee kountain which is the longest of the group (Safford and rillebrew, 1900: 14-15). None of the various ranges Included in the Onaka Frovince is continuous. There are seven rivers, all tributaries to the Tennessee River, which cut the Unakas Into segments (Safford and RIILebrow, 1900: 16). These rivers frequently have steep cliffs along their courses through the mountains, and, according to safford and K11lebrew, were untraversable to travelers unt1l about the turn of the century (Loc. c1t.: 15).

Fenneman (1938; 174) describes these wountalns as subdued, whth sumnits commonly rounded and domes abundent. Crags, bare cliffs, and 
talus slopes are rare. "The slopes of the Unakas, . . are fairly steep on both sides, ranging generally from 20 to 50 degrees. About the interior ridges there is still greater varlation. Some of the rocky faces are preclpitous, whlle elsewhare the slopes are very gentle, ranging from 5 to 20 degrees. But taking the mountains and the valleys together, the land surface with a slope of lese than 10 dagrees is not more than 10 per cent of the whole" "Wessage fron the President . . .," 1902: 21). "The mountalnous rellef of this Appalachian region is tue entirely to erosion in late Cenozolc time, after upwarping of the Schooley peneplatn " Mloore, 1949: 411). Ashley (1930: 700) stated that the uplift of the schooley peneplain occurred some $9,000,000$ years ago, at least not before Kiocene time. Fenneman (1938: 256) concurs in postulating a late or post-Mlocene uplift of the schooley surface.

Remnants of the Schooley surface peralst in the southern and of the Unaka Province on eumites at elevations of about 3,100 feet; to the north it is represented by sumits from 3,800 to 4,000 faet high Fenneman, 1938: 186-187). Braun (1950: 494) considered the uplift of the Schooley peneplain an important factor in the interpretation of the history of the Deciduous Forest Formation. Aside from the possible effects upon the blots of the upwarping per se is the fact that in the region of the Southern Appalachian Mountalns munerous monadnocks and mountalns hundreds of feet high surmounted the schooley peneplain (vide Fonneman, 1938: 172). Thus, such high mountaln peaks as ust. Collins (6,400 feet), Mt. Guyot $(6,636$ feet), and Mt. Leconte $(6,660$ feot) mast have been present in pre-lilocene time, possibly alnce carly Cenozolc. 
Although numerous post-Schooley cycles have been postulated, most of them were only of locel slgnifleance (Tennewan, 1938: 188), and Braun (1950: 494) does not consider these postulated ninor cycles as of general signiflcance to the history of the Declduous Forest Formation. The post-Schooley erosion cycle, termed the Harrisburg, 18 accepted by Braun os occupying the Interval from the upwarp of the schooley unt11 the second major uplift at the close of the Pllocene. This second afor uplift wes the uplift of the Harrlaburg surface.

\section{B. So11s}

Three types of mantle sre recognized In eastern Tennessee (Rodgers, 1953: 115-119). The nost widespread of these 1s res1duun, which ranges In thickness from ten to hundreds of feet. A second type, locally transported mater1el, eccumulates in swales, slakholes, small hollows, larger ersek valleys, and arees edjacent to steeply rising slopes. The third type of mantle is river alluvium. Along the major rivers this has eccumulated to depths as great as 40 feet end consists In large part, especially near the eurface, of allty sand or silty 10am. Sindlar alluviel deposits occur on terraces as high es 400 feet above the present course of the entrenched river. Th1s terrace elluvium differs mot from that of the present flood plain in being strongly leached and oxidized. The alluvium along present flood plains is presumed to have been deposited in hlstorlc times (Rodgers, 10c. c1t.). Terrace alluvium is considered to be of Pleistocene age, are the large aprons of rock and talus mentloned above. 
The solls of eastern Tennessea may be grouped into five associstlons (Tig. 3). The Hartsells-luskingun and Muskingum-Lehew associatlons are asonal 11thosols. These are inmature solls daveloped over sandstones and shalas. They are stony solls with frequant outcrops of sandatone and shala, mediun to strongly acld in reaction, and Iow in mineral mutriants and organic matter. The Hagerstown-Frederick and Portars-Ach associations ara matura zonal solls of the Gray-Brown Podzolic group. Parcnt aterials of the Bagerstowa-Fraderick association are limestones and dolomitic limestones with some shalas. Perent materials of the Porters-1sh association ara granites, gnelsses, and schists, wth soene dark-colorad basic rocks. The soils of anch of thesa associations have falr anounts of mineral mutrients and organic matter and are medium to strongly acld in reaction. The Decatur-DeveyClarksvilla asseciation 18 a group of mature zonal Red and Yallow Podsol1c soils. The parent materials ara 11mastones, and dolonitic and cherty 11mastones. Thesa solls are ganerally strongly leached, Iov in mineral nutrients and organic mattar, and acid in reaction. For more detalled accounts of thase soll assoclations, tha readar 18 raferrad to the "Yearbook of Agricutture" (1938).

\section{Drainage}

The following account of the rivars and streams of the vountain province are from "Message from the President ..." (1902: 28-30).

Probably no region in the United Statas is bettar vatared or bettar drained than this Southorn Appalachian Ragion; nor 18 thare any region which can boast of being the source of so nany streans. . . 


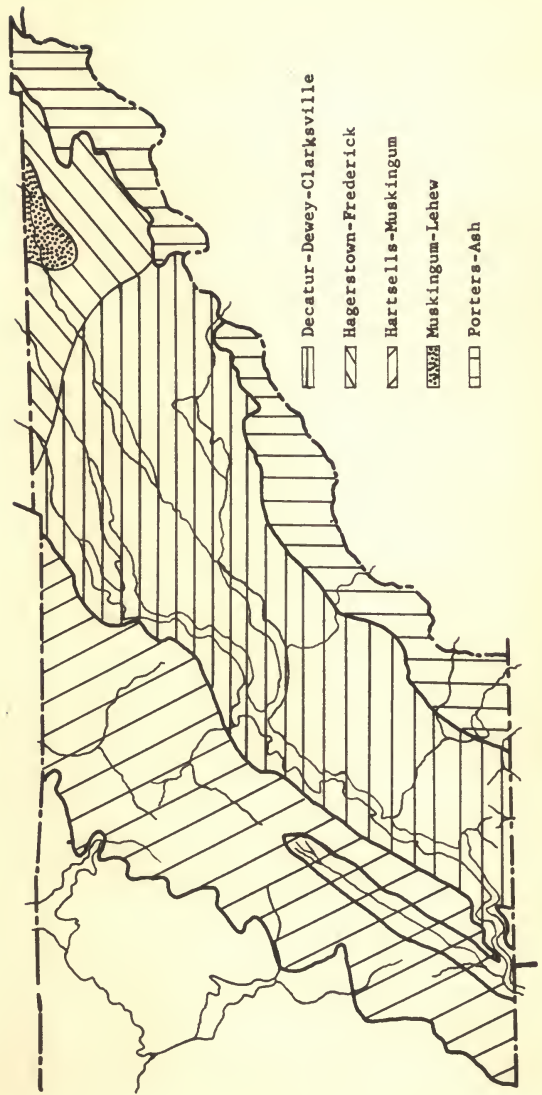

స్. 
In the nountains themeelves these stresme have their sources et elevetions from 3,000 to 6,000 feet, and before reeching level of 2,000 feet many of them have raeched considerable proportions. They subsequently flow ecross the mountein region for distances of from 20 to 50 miles before breaking through the border renges onto the surrounding lowlands at elevetions renging from 1,000 to 1,200 feet. Along their courses stretches of smooth water ere never long, and the descent is often eccomplished by mumerous raplds, cescades, and fells. . . . Such cascades, with descent in short distances of from 10 to 50 feet, are abundant, while in some of the smaller tributarles beautiful fells of from 100 to 300 feet are to be found.

No gorges in eastern Mmarice cen equal in depth and w11nass those carved ecross the Blue Ridge and the Unakes by these atreans in making their way through the merginal ranges of the Southern Appelechiens. . . .

But notwithstending the steepness of the slopes of these gorges, evan whare descent is elmost precipitous, thay are forest-covered except vhere the trees and shrubs have been destroyed by fire and the soll has been removed by the storms.

Bxcept where dana have reaulted In the Impoundment of some of the rivers and streans and where deforestetion has been Incresed, these descriptions bold for present-day conditions.

In contrest to these mountein weter courses are those of these same rivers and streans In the Velley. The ajor rivers, e.g., Hivessee, Little Tennessee, end the B1g P1geon, leave the mountaln province at elevetions around 1,000 feet and enter the Temnessee RIver at elevetions ranging from 700 to 900 feat. Except where knobs and ridges have been bresched, relatively level flood pleins up to several miles In whth have developed. The courses of these rivers through the Valley are winding and in some places rescable entrenched meanders. The banks are steap and exoding es e result of belng cut into the deep residual so11s. Shoels and bars are of frequent oceurrence. At all 
times the water is slightly turbld and the eurrent moderate to strong. As a result of the gystem of the Tennessee Valley Authority dans, the mouths of many of these tributaries to the Tennessee Aver are now drowned.

These impounded areas, Including the backweter Imediately behind the dams, are known locally as lakes. and resenble lakes in physical appearance. A lakelike appearance is enhanced by cattalls and bulrushes In the shallows; by turtles basking on logs and protruding stungs and snags; by shorebirds and ducks working in the shallows and along the shorelines.

Before Impoundment, the width and depth of the ehannel of the Tennessee RIver were extremely variable slong 1 ts course and at different seasons of the year. It is recorded thet Desoto and his aray forded this river in the vieinity of Chattanooga. At Knoxville a flood flov of nearly 100 tines 1 ts nornal flow has been recorded. The gorge of the Tennessee RIver through Walden Ridge was a 30 -mile stretch of narrow rapids variously termed the Narrows, the Suck, the Boiling Pot, and the Frying Pan. From the wastern and of the gorge to Muscle (or Musse1) Shoals was a $38-m i l e ~ s t r e t c h$ of wide, shallow water with numorous eddylng pools. Musele Shoals had a fall of three and one-half feet per mile and is deseribed as having been a serles of rapids dotted with 1slands and segmented by reefs and bars.

The above accounts have been summarized from Davidson (1946: 12-16) and w1111ams (1937: 31-32).

In conversation with residents who remember the Tennessee River before the advent of the Tennessee Valley Authority, I have been told 
of times when $1 t$ was possible to walk across the river vithout getting your feot wet, and in many places it wes possible to vade across. Three major river systems drain eatern Tennessee (Fig. 1). Approximately four-fifths of the area is within the Tennessee aiver Bas1n. The extreme northwestern part of the study area is within the Cumberland Ifver Basin. The extreme southeastern corner of the study area 1s within the Coosa River Basin in Gulf Cosst drainage. Much has been written concerning the eoogeographically Impor* tent phenomenon of strean cepture in the Southern Appalechian Hountains. Fenneman (1938: 187) does not belleve that the direction of dralnage vas affected by post-Mocene uplift of the schooley aurface. The Tennessee River is assumed to have been following its present course prior to this uplift; at least that portion of 1 te course through the gorge of Valden RIdge. There is the posiblilty that this uplift resulted in the capture of such transversely flowing streame as the HIwassee and Httle Tennessee. If $s 0$, thase rivers, unt11 their capture, wat have been flowing northwestward across the Plateau to the Cumberland and/or the western portion of the Tennessee River. There is insufficient geological evidence to support the hypothesis of an outlet for the Tennessee Miver to the southward through the Cooss Valley (Tenneman, 1938: 277; White, 1904). Rather, as suggested by these authors, it is posslble that the Conasauga River in Mocene time ming have flowed-northwestward through the Walden Iddge gorge. Consequent upon the postHocene uplift of the Schooley peneplain this river was captured by the headwater strcams of the Coose River. At present the Conasauga Ifiver 
originates in the wountains of northeastern Georgia and flows northwestward through the southwestern corner of Polk County, Tennessee. Then it turne abruptly south and flows Into Georgia. Near Calboun it joins with the Coosanattee River to form the Dostanaula Rlver.

\section{Climate}

Any discussion of the climate of a faunal area is complicated by discrepancies between zonal meteorology and local conditions in the constituent ecological niches of the area. The mecroelimatic data obtalned frow standard meteorological stations ma be quite different from mieroclimatic date obtained in the sane region (Allee, et al., 1949: 211; Wolfe, 1951). Hovever, auch macroclimatic data are frequently all that are avallable to the blogeographer. There may be some validity in using such data to Infer the general effect of elimate on the diatribution of the elements of the herpetofaune. Shanks (1956) reports a mesn difference of only $0.25^{\circ} \mathrm{C}$. between the teaperature of the soll at a depth of six Inehes and the temperature of the air ae recorded by standard meteorological procedures in a closed forest in the Great Sroky Mountains Mational Park.

Even a general appraieal of the elimate of eestern Temnessee is not easy to make. That the climate varles conulderably both horizontally and vertically may be inferred from the presence of a variety of climax associations in the region (U1de pages 23-29). The molature regim, as interpreted from the date presented in Pigures 4 and 5,18 one with two peaks of maximum precipitation and two periods of reduced precipitation. The two maxim axe due to different causes. The late- 
fall-to-early-winter maximum results from steady rainfall which may be of severel days duration, and et times of severel weeks duration. The sumaer naximum is characterized by thundershowers which produce several Inches of reinfall within e few hours. While there is a decrease in the amount of precipitation In late spring and early surmer, this decrease 18 not as severe as that which occurs in late sumer and early fall. The areas represented by the selected atations differ by only one-half Inch precipteation in late summer but by as much as one inch In the apring. In terms of annuel average precipitation, the Vallay north of Knoxville is the driest part, 44.7 Inches. The Cumberland Plateau (at least around Crossvi110), the Knoxville-Chattanooga Sagment, and the Gatlinburs areas are more nearly alıke; 54.3, 53.8, and 53.8 Inches respectively. The wettest areas in cestern Tennessee are the mountain summits, with a five year average of 90.0 inches recorded at ClIngman's Dome in the Great Scoky Mountelns (Shanks, 1954: 355). Differences in mean monthly tenperatures anong the four areas are not as marked as molsture differences. The coldest teuperatures are recorded from the Cumberland Plateau (Fig. 5). The lowest temperan tures recorded in eastern Tennessee, but not evident from the data presented here, occur on the high sumits of the mountalns. Curlously, the coldest man temperature at high elevations occurs in March (Shanks, 10c. C1t.: 356), while the coldest wonth at lower elevations is January ("Yearbook of Agriculture," 1941: 1119-1121). Conversely, both high and low elevations experience the hottest mean teraperatures in July. Shanks (OP. A1t.: 357) presents data showing that the temperature de- 


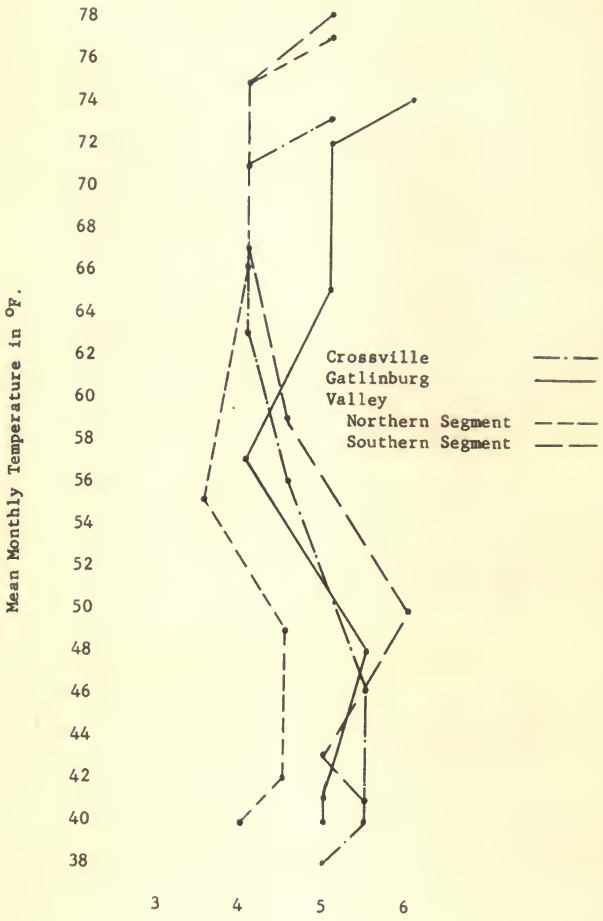

Mean Monthly Precipitation in Inches

Fig. 4.--Warming curves and precipitation from January through July. Read up. 


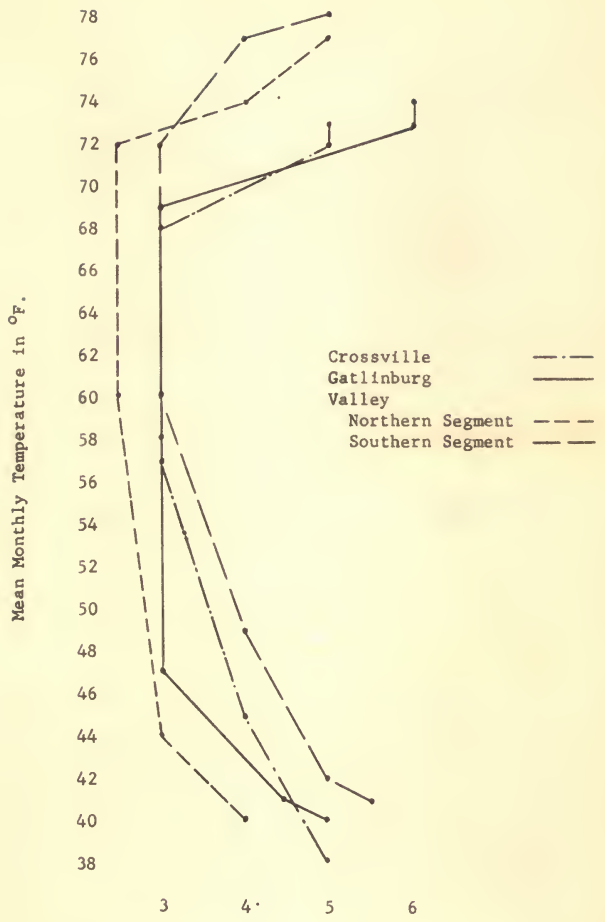

Mean Monthly Precipitation in Inches

Pig. 5.-Cooling curves and precipitation from July through January. Read down. 
creases $2.23^{\circ} \mathrm{r}$. for every 1,000 feet Incresse in altitude in the Great Smoky Mounta1ns.

For a more detalled sumary of climatic data for eastern Tennessee, the reader is referred to the "Yearbook of Agriculture" (op. c1t.: 1119-1128).

\section{R. Vegetation}

The vegetation of eastern Tennessee is varied and complex. Among the factors responsible for this condstion are the varled topography and the great age of the area. With fow exceptions, the doninant vegetation is deciduous forest. Among the exceptions are the secondary forests, the spruce-fir forests of high mounteln sumits, and forests on poorer and drier sites. In the secondary forests and in those on poorer and drier terrain, plnes frequently are the dominant trees. Zonation is evidant in the Unake Mountalns (seneu lato) and in the Cumo berland Mountalns. Frequently it is neceseary to look for evidance of zonation in remnant trees or remant patches of original forest. Ilcewhere, the distribution of the various forest associations seems more related to edaphic conditions. Intensive lumbering operations have destroyed most of the original forest and the forests are generally secondary in nature.

The Tannessee Valley Authority (1941) characterizes the forest: of eastern Tennessee within the Tennessee River Basin as hardwood (IIve types), coniferous (four types), and miredaforest (four types). Bach of these 13 principal forest types 18 subdivided into one or more cover types, totaling 31 associations, as defined by the society of American 
Foresters (1954). Some of the varlous cover types occur in more than one of the principal forest types. The forest reglons shown in Figure 6 are from Braun (1950).

These forest reglons of Breun are not to be construed as synonywous with climax essoclations. Although sach of the regions 18 characcerized by a secific elimax assoclation, these climexes may occur in other forest regions under auitable conditions of habitat. Ne1ther is the area of the forest region coextenstve with the area occupled by the characteristic cllmax association. Secondary forests, nay have an areal extent weh greater than that occupled by climax forest. For detells of the various types of forest comminities occurring in each of the varlous foreet reglons, the reader 1s referred to Breun (1950). For the purposes of this study the following general coments are included (sumarized froa Braun, unless otherwise noted).

The Mired Masophytic Forest Region 18 charecterized by several mixed mesophytle climax associations, which are best developed in the Cumberland Mountalns. The alred mesophytic forest is the wost complex and the oldest assoclation of the Deciduous Forest Formation. From It or 1 ts progenttor have cone all other elimaxes of the Deciduous Forest Formation. During Mocene time this mixed wesophytic forest extended all the way to the Arct1c. Harshberger (quoted by Braun, 1950: 40) deliatted (in part) the northern boundary of this foreat during Pleistocane glaciation along a line froa the confluence of the Onlo and Mgsiesipp1 rivers east to the Cumberland Mountains, thence northward along the Alleghany Nountains to the west branch of the Susquehanne River in Penneylvanie. The mixed mesophytic comunit1es indicate "climatie 


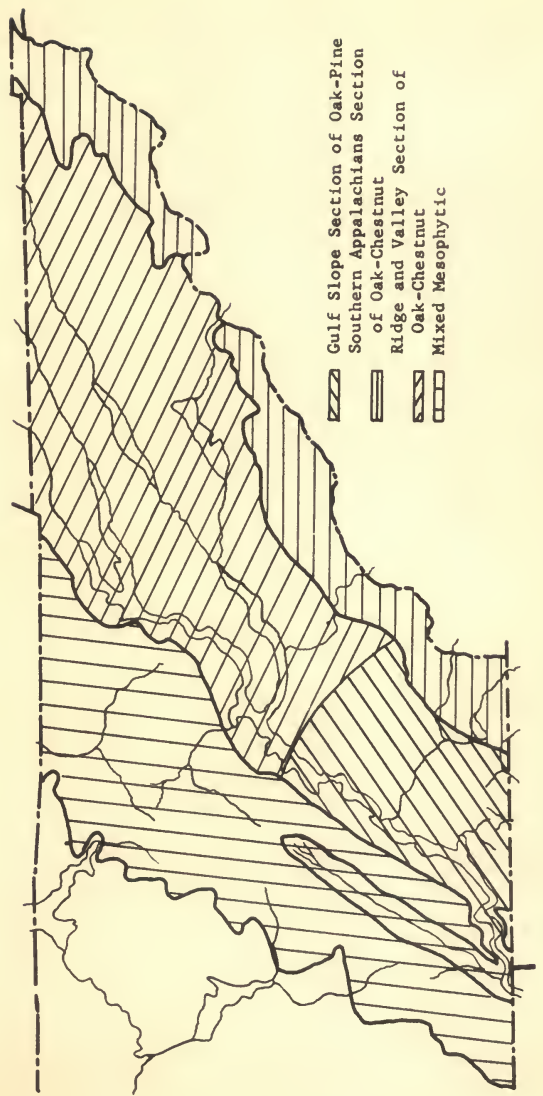

을 
equilibrium." Oak-h1ckory and oak-chestnut commantites on the dry rLdges and lopes in the Mixed Mesophyt1c Degion are edaphle climaxes whlch have aegregated from the mlxed forest. Locally, pralrie vegetation, northern vegetation, and cosstal plaln plants are to be found. These are Interpreted as relics aurviving changes in climatic and physiographle conditions. The occurrence of mixed mesophyt1c coumuntties outelde of this region is correlated with peculiarities of local enviroments. W1thout known exception, the local habltats occupled by these extraregional communities are mesic slopes. In the Snoky Hountalns such comountties are knomn as cove forests. In the Rldge and Valley section of the Oak-Chestnut Forest Reglon, mixed mesophyt1c comnunteles are Ifmited to valley lopes of the present eroslonal cycle.

The forest communities of the surface of the Cumberland Plateeu are quite distinct in appearance from those of the Cumberland Vountsins and fron the coves and stres valleys which Inclse the plateau margin. Depending upon site, the molst slope and valley forests are beech and white oak, henlock and white oak, or beech, hemlock, white oak, and tuliptree. In contrast with these communities are the oak and the oak and hiekory forests of the plateau surface. Anons the prevalent tree species are quercus alba, 9. montana, 9. Ealcats, 9. stellats, Carre glabra, C. tomentose, Cornus floridans, R1mus echinata, and E. virginians. Along cliff marging are pine-heath communities. In swampy places red aple prevalls. A further point of contrast between the plateau surface conmunitles and the mixed masophytic communities Involves canopy closure. 
The mixed mesophytic forests typleally exhlbit a dense, closed canopy when the trees are In full follage. According to Braun (1950: 113), the large showy summer-blooming herbeceous plants in the plateau surface conmunitiee suggest that there have alvays been open aunny apots. These herbaceous plants are not characterlatically found in the andxed mesophytic forest comaunity.

The Oak-Chestnut Foreat Region 18 characterled by the former dominance of oak-ehestnut forests on most slopes and the doninance of whte oak forests on the Valley floor and extensive flats. Iro sectlons of this region occur in eastern Tennessee: (1) the Southern Appelachian Section, (2) the Ridge and Valley Section.

In the Southern Appalachlan Forest Section three principal forest groups are recognszed: (1) northern forest, mostly at elevations In excess of 3,500 feet on northern slopes, (2) wolst slope and cove forest, (3) dry slope and rldge forest. The last groups occur at moderate to low elevations. The northern forests are divided Into northern hardwoods forest-whth sugar aple, yellow blrch, beech, and buckeye as the important tree specles--and spruce-fir foreet. As w111 be discussed later, the opruce-fir forest is not interpreted as an outliner of the northern consferous forest. At elevations around 6,000 feet the trees become dwarfed. The stands are open and are referred to locally as "orchards." The wolst slope forests are characterlzed by oak-ouercus albs, 9. borealis, 9. pontans--and, formerly, chestnut. These forests occupy elevations between 1,300 and 4,500 feet or higher on the southern slopes and almost without exception have an erleaceous understory. 
The cove (mired masophytic) forests occupy the deep ravines of the mountain slopes. The transiclon between molst slope oak forests and cove forests 18 gradual. On the drler ridges and south slopes the for. eats are oak=-9. falcats, 9. mar1land1ce, 9. stellate-mor oak-pine communit1es. The principel pines are Plmus echinats, $\underline{R}$. pungens, and $\underline{\underline{R}}$ r1g1da. Briceceous shrubs are abundant. These dry slope forests are rather sharply set off from the oak forests of northern, masic slopes. The Rldge and Valley section of the Oak-Chestmut Forest Reglon 18 (or was) cheractarized by wh1te oak forests. These oak comaunst1es differ from those of the mountaln slopes in having an herbaceous rathar than an arlcaceous understory. On 10w shaly r1dges black oak and hicko* ry become prominent. Southern plnes also become more Important, esper.1ally in young secondary stands. As montioned previously, alred mesophyt1c communities occupy ravine slopes in this section.

The Gulf slope Section of the Oak-P1ne Forest Region 18 characterlzed by oak-h1ckory climares. There 18 almost a universal doninance of pine in the forest communities. The pines are nost prevalent in successionel and subclinax stands. Th1s region is transitional between the central dectduous forest and southeastern evergreen forest. Horeover, the transition between the oak-chestmut region and the oak-pine region 18 so gradual that the boundary 11 nes are necesearliy arbltrary.

On some of the mountaln sumates of 5,000 feet and more in the Danke Province, particulariy in the Great smoky Nounta1ng, spruce-fir (P1cee rubens-Ables freser1) forest 1s climax. In physiognouy this forest appears to be an outlier of the northern confferous foreats. 
The fir is endemic to the Southern Appalachian Hountains and a number of the understory species do not occur in the northern coniferous forest. Shanks (1954: 360) has shown that these spruce-fir forests exlet In a climate much wetter than that of the northern confferous forests. From these data presented by Braun and Shanks, I conclude that these spruce-fir forests are not disjunct communities of tha northern coniferous forest.

Another feature of the sumits of some of the higher peaks is the occurrence of treeless areas clothed with grasses or heaths, referred to reopectively as grass or beath balds. Whittakar (1956: 56) states that in some instances they may represent primary seral stages: while in other instances thay may be secondary, and a result of the destruction of forest. He concludes by regarding then as topographic climases, or, as parts of a complex climax pattern. Wells (1956) states that these balds are "artifacts or archeological disclimaxes" representing "camp sites of early hunter Indians who preceded the low" Iand Cherokee farmer of Bartran's day." B1111ngs and Mark (1957) discuss the persistance of treeless areas regardless of their geographical location. Among the factors discused as responsible for the persistence of balds are (1) Inability of most tree seedlings to withstand the severity of the environment of bald areas, (2) occupancy by the balds of ecotonal areas at the margin of or beyond the tolarance renges of the Important regional tree species, and (3) extremes of cliantic cycles which may eliminate cartain tree species or reduce the population so that the variety of avallable blotypes is sall. Regardleas of their origin, evidence suggests that these areas may become forested (Brown, 1953). 


\section{THE BERPETOFAUMA}

Twenty-seven forms of salamanders, 16 of froge and toads, 14 of turtles, 9 of 11zards, and 30 of snakes are discussed in the followIng accounts. If the forms In the subfanily Deemognathinae were Included, the numbers of salamanders would total at least 37 . One conspicuous feature in the following accounts is the large number of Intergrading subspacies. A parallel sttuation among mamals of eastern Tennessee may be inferred from data presentad by Handiton (1943). Among 60 forms of anmals reportad as occurring in eastern Tennessee, 12 of them represent 6 species.

\section{A. Class Anphibla \\ 1. Order Caudata}

This order 1 sepresented in eastern Tannessea by 6 fanllies, Including 2 subfanilias, 13 genera, and a mintmun of 19 species, excluding the specles of the genus Desmognathus, the Dusky salananders, and of the genus Larognathus, the shovel-nosed Salananders.

\section{Fandly Cryptopranchldae}

Gemus Cryptobrenchus, Hellbenders. M1shop (1943: 59-60) Includes portions of eastern Tannesee in the ranga of the Hellbender, Cryptobranchus allegeniensis (Daudin). Schmidt (1953: 11-12) wakes the Ozark Hellbender, Gryptobranchus b1 shop1 Grobman, conapecifle with $\mathrm{C}$. alleganiensis and Includes eastern Tannessea in the range of $\mathrm{c}$. a. 
allegentens1s. However, $\$ 1 x$ specimens of C. alleganlencls--four females, two males--collected during the course of this study seem Intermedlate In a number of respects between C. S. allegenlensis and C. a. b1shopl. As Grobman (1943; 6-9) did not dist1ngulsh between the sexes In his description of C. b1ghopl, the data from these six specimens are not separated as to sex.

C. A. alleganlensis may be dietinguished from C. A. bishopl by the ret1o between the diemeter of the spiracle and Internarial distance, the ratio between Interorbital distance and Internarial distance, the number of prevomerine teath, and color. Meristic data obtalned from the slx specimens are as follows: ratlo between Internarial distance and dlameter of splracle, range 1.2 to 3.6 , man 2.4; rat10 between Interorbital distance and Internarlel distance, range 2.1 to 2.6 , mean 2.4 . The number of prevoeerine teeth ranges from 33 to 55, mean 42.3. Grob$\operatorname{man}(1943: 6)$ reports only a single value of 3.8 for the rat1o between Interorbltal diatance and the dlameter of the spiracle In C. blshopl; a value of 2.0 for this ratio in C. Allegeniensis. None of these $\mathrm{sx}$ specimens has this ratio as great as that reported for C. blehopl and only one has a ratio as amall as 2.0. The mean value for the ratio between Interorbital distance and Internarlal distance and the maximum and nean numbers of prevomerine teeth of this serles are larger than the corresponding values of these characters reported for elther c. blshopl or C. Alleganlensle (Grobman, 1943: 8). If the count of 55 prevomerine teeth 18 deleted from the counts of the $s 1 x$ specimens, the range is then 33 to 47 , mean 39.8 , which agrees more closely with these same values for C. Alleganlensie. 
c. blshopl and C. alleganlensis are apparently more different from each other in matters of coloration than in body ratios. It is this character particularly which wakes the olx castern Iennessce epecimens more like $\mathrm{C}$. blshopl then like $\underline{\mathrm{C}}$. Allegenlensis. Three of the six specimens have black spots on the chin, and a fourth specimen has these opots plus a fev large brown blotches on the lateral surfaces of the lower lablal reglon. This is the type of chin coloration aseribed to c. blshop1 (Grobman, 1943: 8). The remaining two apecimons lack the spotting on the chla. These elx epecimens have a ground color more like a topotyple spectmen of $\mathrm{G}$. blshopl than like thet of a $\mathrm{C}$. allegantenele from New York. Further, all of the specimens but one have large brown or black blotches on the posterior one-half to two-thirde of the body and on the lateral surfaces of the tall. Each of the specimens has black punctations on the ground color of the doreum.

All of the specimens are from localities within the Tennessee River Basin (Fig. 7). The localities are at elevations ranging from 800 to about 1,500 feet. King (1939: 548) reports a specimen froe the Little River at an elevation of 2,200 feet. Gentry (1955; 169) reporte that $\mathrm{C}$. Illeganiensis is coumon in the Cumberland River watershed.

\section{Fanily Proteldae}

Genus Necturus, Waterdogs. Fleld work during this study has produced only a single specimen of this genus. This is a female with a snout-vent length of $167 \mathrm{~mm}$. and a total length of $244 \mathrm{~mm}$. It is from the Conasauga Creek, Monroe County (Fig. 7). This creek is a tributary to the Hiwassee River. Ring (1939: 546-548) discusses specimens from 

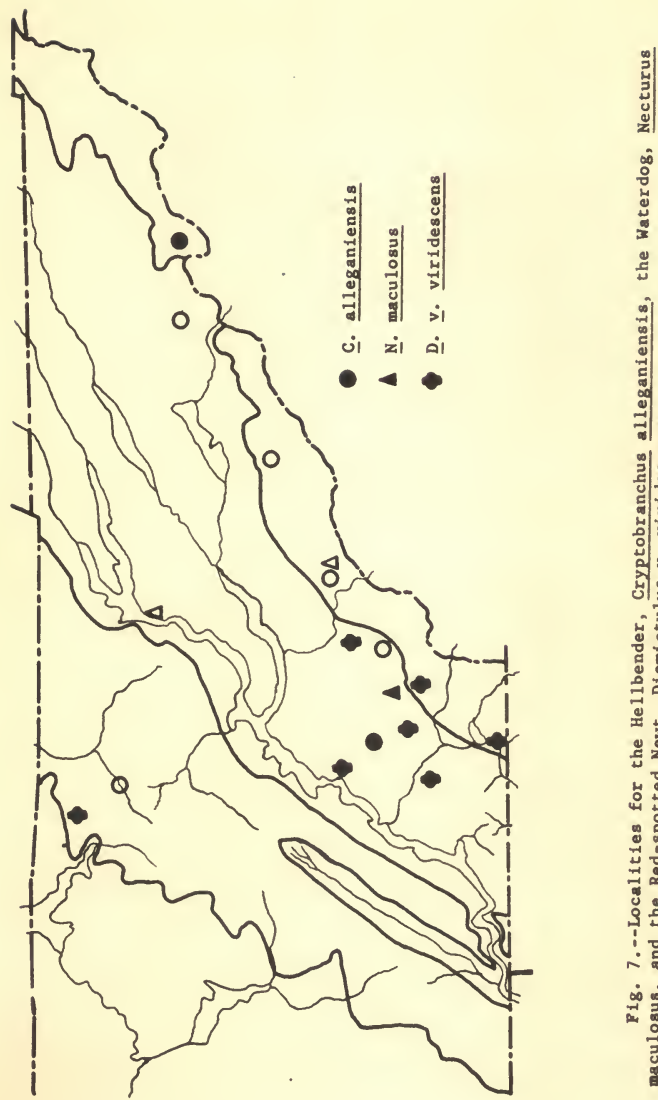

实

논

क्ष

矛龍

剀

겅

मे

वี

포.

起完

岁 亗

๓

ti

$\exists \propto$

오ํ

:

.

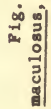


the Clinch River below Norris Dam and from Abrams Creek in the Great Snoky Mountalns National Park. Interrogation of local sport end commerclel flshermen ebout encounters with Necturus has resulted in negatIve replles. Conversely, most of these persons are fandliar vith Cryptobranchus.

It Is Impractical to epeculate upon the systenatie status of a population on the basis of one spectmen. However, this opecimen is

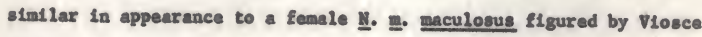
(1937: 129), King (1939: 546) flgures a female designated as $\underline{\mu}$. maculosus $\times$ elabamensls fron the Clinch River. It appenrs to differ from the specimen reported here in posessing large irregular shaped dark spots and in having wore extensive IIght areas on the venter. There is essentialiy no difference between the meristic date avallable for this specimen and those reported for females from the Clinch River by Ring.

\section{Fantly Sirenidae}

Genus Stren, SIrens. Although I have not encountered nembers of this genus in eastern Tennessee, it is included on the basis of a verbal communication from Mr. Ernest Liner of Lafayette, Loulatana.

Vr. Liner Informs me that he collected a specimon of the Greater Siren, Siren lacertina Linnaeous, from a strean or roedelde ditch in Knox County. This specinen may represent a veak population or an escape. I would suspect the latter; in the past few years the newspapers have carrled severel accounte of boa constrictors having been kllied in eastern Tennessee. 
Fandly Ambystomidae

Genus Ambystoma, Mole Salamanders. I have personally encountered only three species of thls genus in eastern Tennessee. These are the Spotted Salamander, Ambystoma maculetun (Shaw), the Karbled Selemander, Ambyetome Opacum (Gravenhorat), as egse and larvae only, and e single male Tiger Salenander, Ambyetoma t. tigrimu (Green). There is an early litereture record of the Jefferson Salanander, Ambystoma Leffersonianum (Green), from Roan kountaln et elevetions from 4,000 to 5, 200 feet (Rhosds, 1895: 382). Schmidt (1953; 19) in referring to the range of $\mathrm{A}$. Affersonianum reports it is of "isolated oceurrence in - . Tennessee," vith Tennessee not qualified as to East, Mddle, or Weet. Judging fron the distribution of this form as given in Bishop (1947: 133), I Infer thet thio 1solated occurrence wet be in West Tennesese. Schnidt (page 21) 1 so includes Tonnessee vithout quelificat1on In the range of the Small-mouthed salamander, Ambystomn texamum Qlatthes). Bishop (page 157) shows only the northwestern corner of the stete as being Inhabited by this selamander. Bishop (page 160) does not include eastern Tennessee in the range of $A$. ㄷ. thgrinum.

4. maculetun is represented by a serles of seven females and three ales plus mumarous egs clusters from widely veettered locelities (P18. - ). Mariatic data from these spectmens are as follows: snoutvent lengths, range $86 \mathrm{~mm}$ to $116 \mathrm{~mm}$, mean $106.3 \mathrm{~mm} .1$ tell lengths, range $67 \mathrm{~mm}$. to $91 \mathrm{~mm}$., mean $79.2 \mathrm{~mm}$ i costal grooves, range 12 to 13, mean 12.5; number of dorsal spots, range 17 to 45 , mean 28.5 . As regards these meristic characters and color, these opecimons agree with 

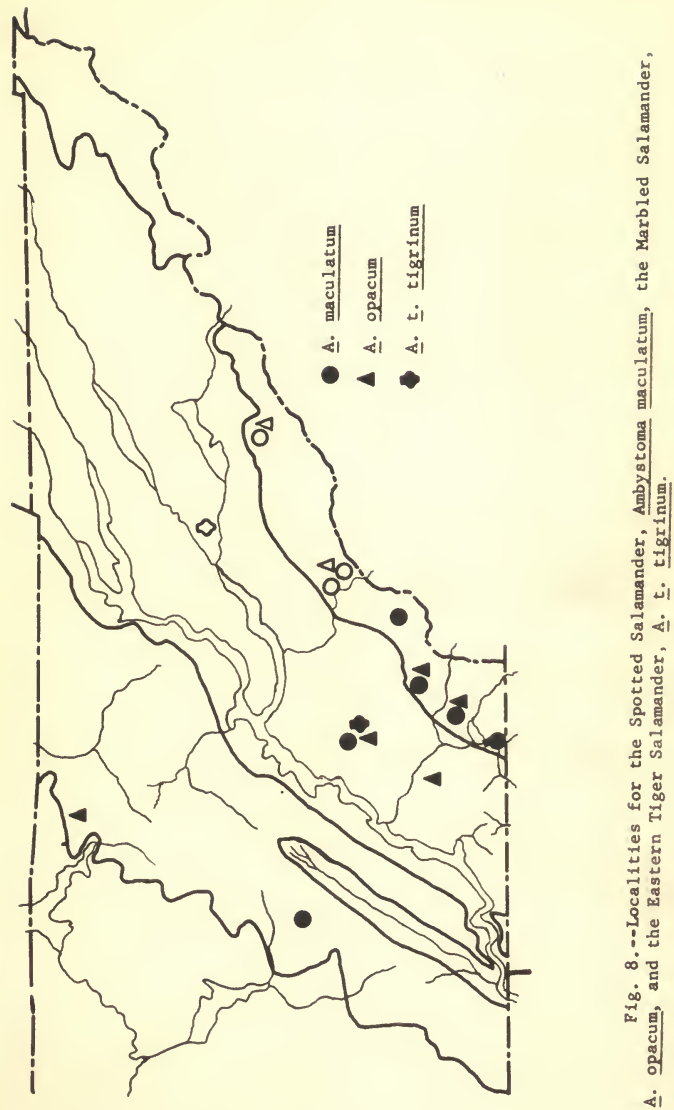
the description of this species a given by Blohop (1947: 144-145). Thls epecies, whlle widespread in eastern Tennessee, seens to be conIned wore to the heavily forested areas, especially in the Unaka Prov1nce. The highest elevation from which $1 \mathrm{t}$ has been collected is approx. imately 2,000 feet.

While the ambystomids are characterized as pond-breeding salamanders, the paucity of ponds in the nountains does not seem to hinder A. maculatum. Aumerous egs nasses and several spent adults were collected in a roadside ditch carrying rainfall runoff in the mountalns. In a sping seep area not far distant frow this ditch there were no indications of breeding by the spotted Salemander. There is a locallty In Polk County where this selamander regularly breeds in a spring-fed stream of woderate eurrent and vith a depth of 8 to 12 inches. The abcence of breeding of the spotted salansnder in the above mantioned seepage area would seen to be the to lack of wufficlent depth to the vater. It was at that time only about four or flve Inches deap.

As mentioned above, A. gpacues is known by me only from eggs and 1arvae. Hence, the distribution of this salanander In eastern Tennessee is based upon collection sites of these stages of the IIfe cycle and upon 1iterature reports ( $\mathrm{Fg}$. 8). It is interesting to note that it seems to be nost abundant in the Valley Frovince. Although infrequently collected in the same pool where A. naculatum breeds, these sal amanders seem to breed in mutually exclusive areas most of the time. This difference in habitat preference is so noticeable, in my experience, that I an Inclined to characterise A. opacun as a slade or forest-edge Inhabitant. 
The highest elevation from wh1ch $\underline{A}$. Opacum has been collected is around 1,800 feet.

The single male A. $t$. tigrinum is not different from published descriptions of this salamander. That it represents a population in eastern Tennessee ay be questioned. It was collected on a porch durIng a hard spring rain. Following 1ts capture, it was placed on display in a store window in the bualness section of Athene. During that time, no one was bble to report ever having seen such a "11sard." The place where $1 t$ was captured is adjacent to a lumber yaxd, and it is possible the antmal was brought In vith a ahipanent of cedar loge from West Tennessee. Gentry (1955: 170) reports th1s salanander as common In West and Mddle Tennessee and as having been collected In Knox County (F18. 8).

\section{Fanily Salamandr1dse}

Cenus Dlenictylus, Bastern Newts. The newts of eastern Tennessee are referable to the eubspecies Diemfetylus $\underline{v}$. virldescens (inf1nesque). The series of 18 females and 41 males and 2 of undertermined sex, one of which is in the red eft stage, do not differ from the deseription of this form as given by B1shop (1947: 100-102). The largest female and anle in total length (snout-vent length in paratheses) are $108 \mathrm{man} .(52 \mathrm{~mm})$ and $114 \mathrm{~mm}$. (51 m.) respectively.

Th1s salamander is characterlstic of woodland pools and coves of the T. V. A. impoundmants, and not infrequently is found in the headwater spring pools of smaller streans and branches. There seens to be no special prediliction for any of the physlographle or forest regions. 
Tamily Plethodontidae, Subfansly Desmoganthinae

Genus Desmognathus, Dusky Salemanders. Bxcludad from this study.

Genus Leurognathus, Shovel-nosed Salamanders. Excluded from this study.

A brief statement as to which species of these two genera are raported as occurring in astern Tennessee 18 appropriate. These speclas w11l be left out of analysis of the herpetofaune bacause of the confused taxonomic state of the genus Deamognathus and of lack of $1 \mathrm{n}$ formation on the distribution of the genus Leurognathus in eastern Tannessee.

Schnidt (1953: 29-32) Includes eastorn Tennessee in the ranges of five specias of Degmognathus: the Northern Dusky Salanander, Dermog-

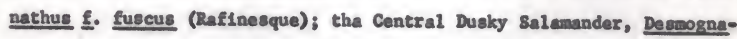
thus E. brimleyorum (Stejneger); the Allegheny salamander, Desmognathus ochrophaeus carolinensls Dunn; the Ocoee Salamendor, Degmognathus ocose Micholls; (?) the Appalachian Seal salamander, Deomognathus $\mathrm{w}_{0}$ monticala Dunn; the Bleck-bell1ed Salamander, Degrognathus qundramaculatus (Holbrook); the P1guy Salanander, Degmognathus urighti Ring. Mr. Barry Valantine (personal communication) inforas me that some of ay apecimens of Degmognathus are the Cherokee Salamander, Desmognathue aeneus Brown and Blshop.

B1shop (1947: 220) reports the occurrence of the Northern Shovelnosed Salamander, Leurognathue 트. marmorate Moore, from Roan Mountain, Caxter County. King (1939) reports opecimens of the Southern Shove1nosed Salamander, Leurognathus m. Intermedis (Pope), from the Cades Cova area of the Great Snoky Mountaine National Park. 
Fanily Plethodontidae, Subfamily Plethodontinae

Genus Plethodon, Woodland Salemanders. The besis for the following ramarks is the monogreph of this ganus by mighton (OLS), unlase othervise qualifled.

Three specles of the Lasteru Saull Plethodons and three species of the Bastern Large Plethodons are reported es occurring in eastern Tannossee. The Eastern Snall Plethodons are es follows: Wellert Salamander, Plethodon wellers Valker; 21 grag Salamandar, Plethodon d. dorsells Cope; Red-backed Solamander, Plethodon s. clnergus. On the basto of Highton's distribution wap for the subspecies of plethodon richmonds, It Is possible that a fourth mamber of this group. Pope's Ravine Salaander, Plethodon I. Poper Mighton and Grobman, may be discovered in the northeestern part of Ionnessec. The Zastern Large Plethodons in eastern Tennessee are es follows: Yonahlosee Selamander, Plethodon yonshlosee Dunn; Red-cheeked Salamander, Plethodon 1. Lordant Bletchleg: Dnseol salamander, Plethodon 1. unfcol Highton; Metcalf's Salamander, Plethodon 1. metcalf1 Brimley; slimy selamander, Plethodon 8. glutinogus (Green). Wone of the localities shown for P. \&. glutinosus 1s from Highton (as) es he does not present a detalled dietribution map for this subspectes. I. C. clnereus and I. I. doreells are shown as occurring in the same locallty (F1g. 10). Th1s locallty is based upon data glven to we by Dr. Highton, and, eccording to hlm, are "Zing's ident1fications." Both are from White Oak s1nk, Great Sanoky Mountelns Hat Lonal Park.

Bech of the above salamanders is a forest snhabitant. In m experience, I. c. clnereus and I. g. glutinosus have the greatest ecologi- 
cal tolerance of all the plethodons in eastern Tennessee. Bach may be ancountered in a variety of situations ranging from edificarian habitats to dense forests. One factor which seems common to all localities where I have encountered plethodons is a wll or mor type of surface layer of the soil. That this is not fust a consequance of their 1nhabiting forests is inferred from the relative absence of these salamanders in the grazed forests where the top soll has been compacted. This is the case In the mountalns as well as in the valleys. Leaf 11tter and a canopy of trees alone do not seem sufficient to support them.

Iive of the eight plethodons in eastern Tennesses have known distributions confined to the mountalns of eastern Tennessee, western North Caroline, and southwestern virginia (Fig. 9). The elevation at whlch they are known to occur are as follows: P. 1. 10rdant, P. wellers, P. yonahlossee from 2,500 feet to above 5,000 feet; P. 1. petcalfe from 3,000 to 5,800 feet; P. 1. unicol not below 4,000 feet. The remaining three plathodons are of widespread occurrence in eastern Tennessee (Fig. 10). Blevations at which they are known to occur are af folLows: P. C. cinereus, P. R. glutinosus up to 5,000 feet; $\underline{P}$. d. dorsalis up to 2,200 feet.

Genus Hemldectylium, Four-tood Salamander. King (1939) reports this salamander from the Great Sanoky Mountalns National Park (Fig. 11). It is known frow only two localities in the Park; Cades Cove and the head of Meadow Branch at an elevation of 1,800 feet. The site in Cades Cove 18 a emall gun swang with a ground cover of leaf litter and sphagnum moss. The head of the Meadow Branch is a sphagnum bog. I have 

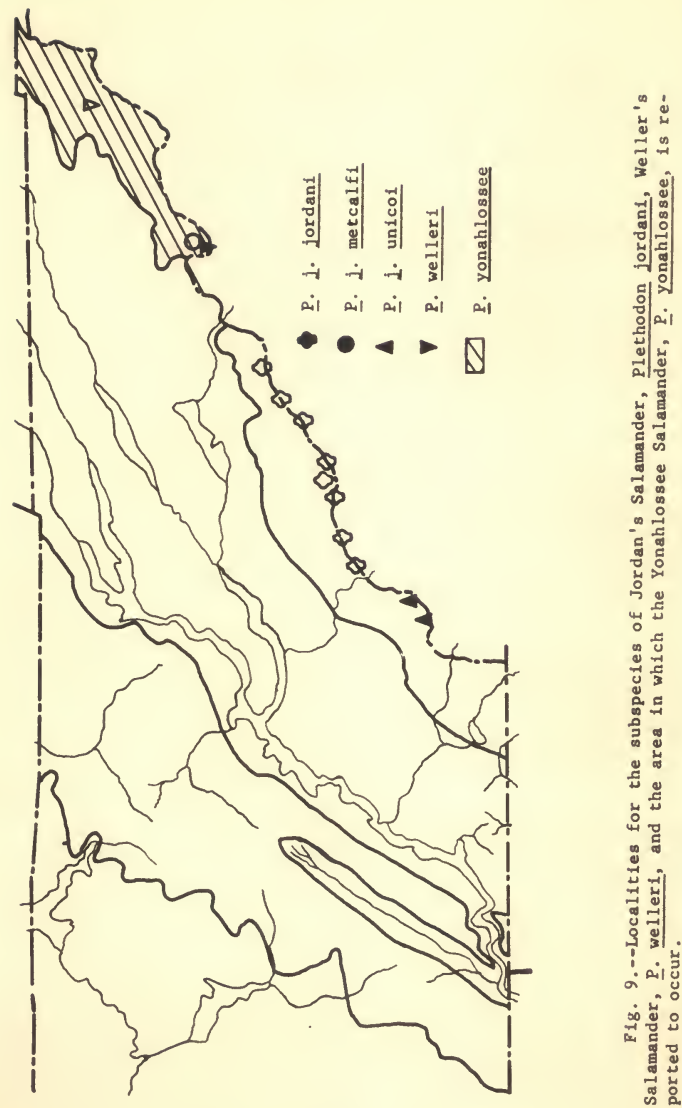


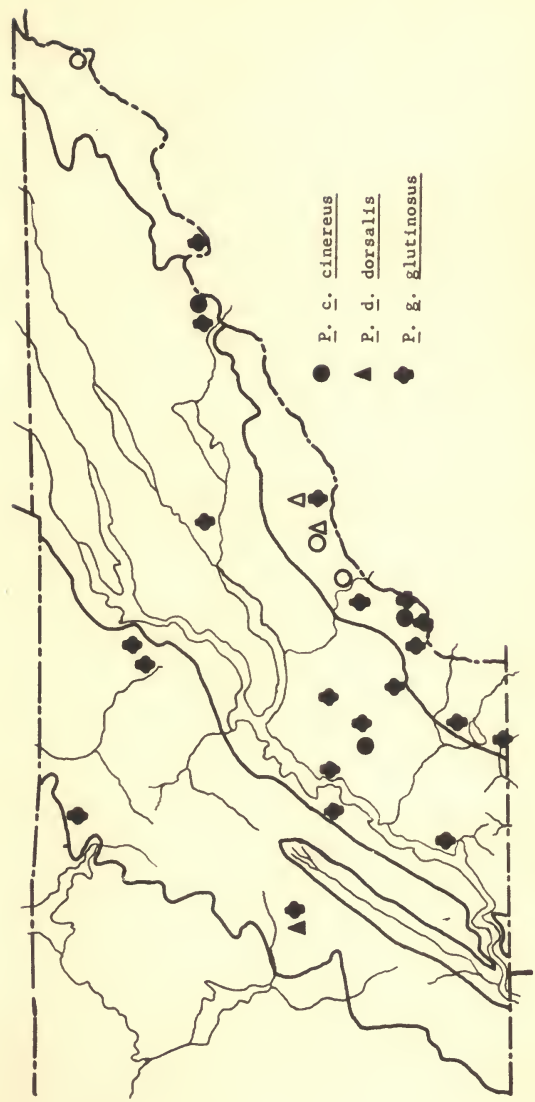

ปี

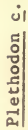

芼

- 00

آำ

\%

คิ

ชै ซ్

ปี

离

क ज्ञ

东

둔

ชึ

드

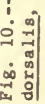

बi

i 


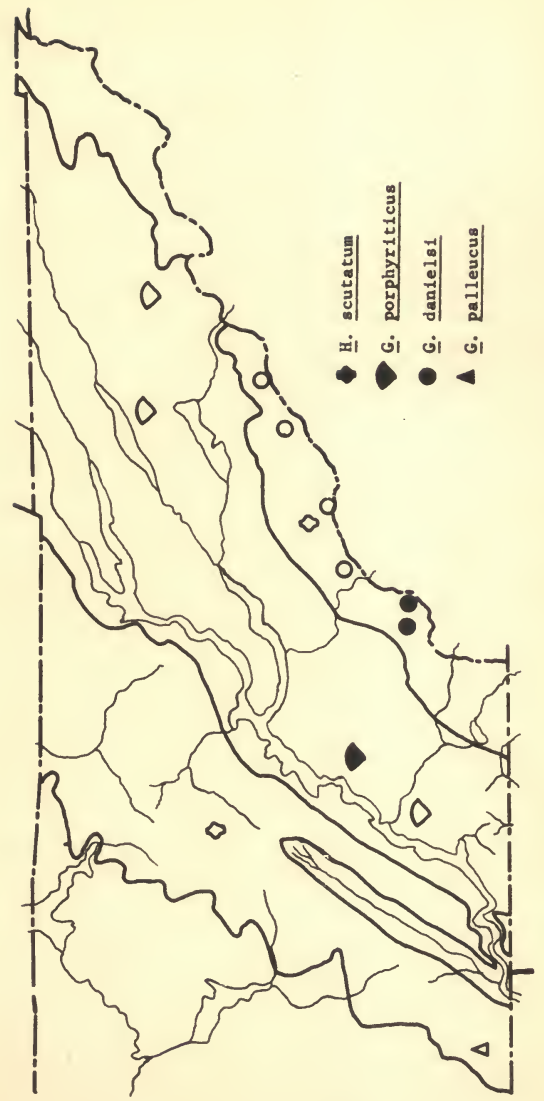

मूँ

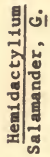

कै

본

㐘

모

○

马ำ

है

ปี

उี

: 등.

ㄷํㅇํํ

$\infty$ 침

a

ฮู 
searched in sphagnum combunities in the mountains and in the Valley whthout encountering th1s salamander.

Gemus Grrinophilus, Spring Salamander. Schaldt (1953: 45-47) Includes eastern Tennessee in the range of the Northern Spring Salamander, Gyrinoph1lus R. porphyriticus (Green), and the Blue Rldge Salamander, Gyrinophilus d. danielar B1shop (F1g. 11). B1shop (1947: 362) Indicates Intergradation between G. d. danielel and the Carolina spring Salamander, Gyrinophilus dunni Mittleman and Jopson, in the mountainous central portion of extreme eestern Tennessee. Gentry (1955: 172) reports G. R. porphyritious as common on the Cumberland Plateau and as occurring in northeastern Tennessee.

All but two of the specimens of this genus which I have collected are In the possession of Mr. Barry Velentine, Mississippl Southern College. Consequentiy, except for the two avallable specimans of G. dantelsi, texonomic designation of the other specimens are those entered in the collection catalogue and may be suepect. Two of these are recorded 28 G. R. porphyriticus and one as G. danielo1. The two G. R. perphyriticus are from the twilight zone of a cave in Melgs County in the Valley Province, elevation 900 feet. The G. denielel 18 from e spring seep at Whigs Headow, Monroe County, alevation 5,000 feet. The two specimens of $G$. danfelsi discussed below are slso from Monroe County. One is from en elevation 1,800 feet, the other from 4,000 feet.

Neristic data from these last two specimens are within the range of both G. I. dantelsi and G. d. dunni. As regards the comblnation of tooth counte, cosstal grooves, and color, these specimons seen to be intarmediate between the two subspecies. The high-elevation specimen has 
the reticulete brown pettern, the knife-edged distal part of the tall, and the seven vomerine teeth preceding the bend as reported for G. d. dantelsi. It resembles G. d. dunnt In possessing 18 coestel grooves, dorsal spotting, and having the legs marked lika the dorsum. The lowelavetion specimen resenbles G. d. Canielst as follows: sides of the head converge toward the gular fold; knife-edged keel on tha distal part of the tall; 18 coastal grooves. It resembles G. d. dunnl as follows: 15 vomerine teeth preceding the bend; acuta band in the vomerine series of teeth; suggestion of e herring-bone dorsel pattarn.

McGrady (1954) described the neotenle Tannessee Cave Salamandar, Gyrinophllue pallaucus, from cave near Sewance, Frankiln County (F1g. 11). This locality is in the southarn and of the Cumberland Plateau. I have collected saveral Individuels of an unldentified "glant" Grainophllus larve et Athans, Mclinn County, In the Valley. The collection site 18 a roedside ditch which becomas flooded by the Oestanaula (lastnalle) Creek. These specimens were collected et a time when the ditch was flllad with flood weter. They were near an opening to a hole In the ground about tha size of e woodchuck burrow. Bxamination of the hola after the vater receded felled to disclose $1 \mathrm{ts}$ axtent. Preaumably It conmunicetes with underground solution channels which abound in the orea. Selning and trepping in tha edjacent craek produced no additional specimens. Thase three ara also in possassion of Mr. Valentine.

Genus Pseudotriton, Rad Salamanders. Schntdt (1953: 48, 49) records the Mdland Salamander, Pseudotriton montanus diastictus Blahop,

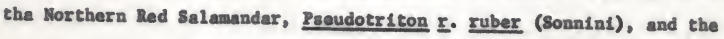




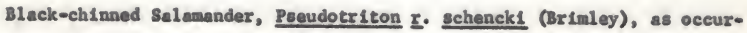
ring in eastern Tennessee (F1g. 12). Bishop (1947: 390) shows extrume northeastern Tennessee withln the range of the Blue Ridge 8alamander, Peeudotriton I. nit1dus Dunn. The exact locallty given is Roen Mountain, Carter County. King (1939: 557) records the Eastern Wud Salamander, Peaudotriton $\mathrm{g}$. montanus Baird, from the sinks on Little River and Mt. Steriling in the Great Smoky Hountains Kationel Park. As King's paper antedates the deseription of $\underline{P}$. 1 . diestictus, it 18 probable that these epecimens are referable to this oubspectes. Wy collecting has produced only one species, ‥ ruber.

Forty-three specinens (14 feneles, 27 males, and two of unde-

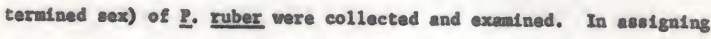
these specimens to $\underline{\text {. }}$ ruber rather than to $\underline{\underline{B}}$. montanus, I used the key characters of B1shop (1947: 376) and Brimley (1944: 21). Special emphasis was placed upon spotting, configuration of vomarine teeth, and the presence or absence of a dark 11ne through the eye to the nostril. These specimens range in total length (snout-vent lengths in parethese8) from $69 \mathrm{~m}$. (43 m.) to $156 \mathrm{~mm}$. (98 m). Costal groove counts are ss follows: 16,36 specimens; 17,5 specimens; $16-17,2$ specimens. The number of costal folds between appressed $11 \mathrm{mb}$ is not considered because Grobman (1943) has demonstrated that this is an ontogeneticaily variable character. None of these data per se 18 oufficient

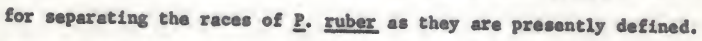
However, 19 of the specimens exceed the meximum total length recorded by Bishop for I. I. nltidue; 14 of them exceed the maximum length recorded for I. I. schencki; one exceeds the maximum length recorded for 


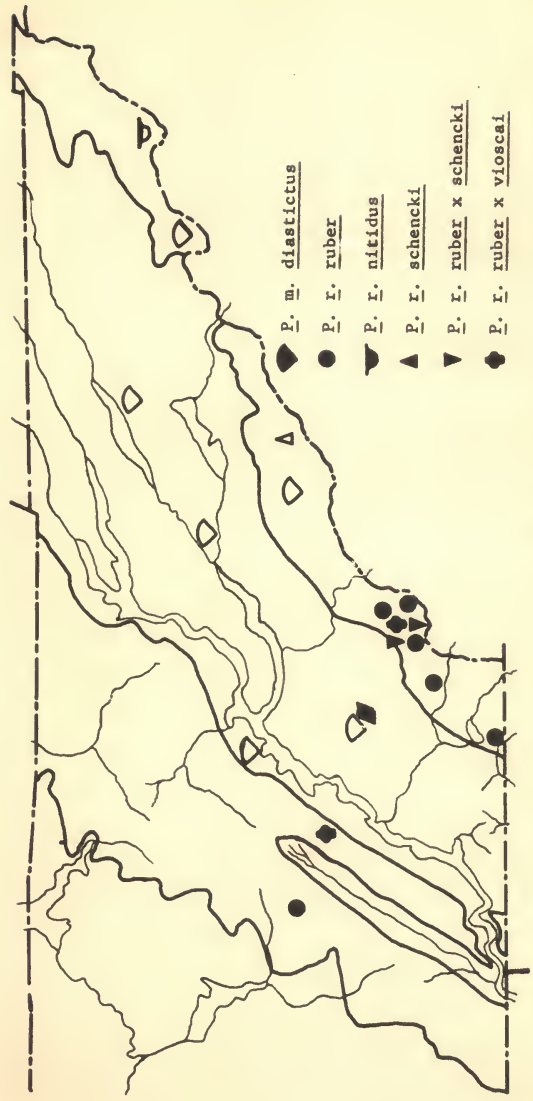

离

。.

罢

की|

․ํ क्

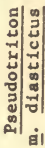

मैं

嵒

कै ต

ณ

글

ㅇํㅇ

건 임

总

फे में

จ ริ

it

$\exists$ م

ปี

马ै

i.

국

.

붕

응

론 
P. I. vioscel. The taxonomic allocation of these specimens is based primarily upon coloretion. Also, these specimens were compared with Identified materiel in the University of Florida collections.

On the basis of dorsel coloration, it is posalble to arrenge all specimens into a continuous serles. At one extreme are those havIng a pattern of distinct apots on a coral pink background with no secondary spotting of smaller brownish or black spots and stellate markings. At the other extreme are those specimens hoving the primary and secondary spotting nearly obscured by a purplish-brown color. Thirty-one of the specimene poseses large frregular shaped black spote, many of whleh coelesce, with smeller, browntoh to bleck punctetions and etellate anarkIngs in the speces between the primary spots.

The upper surfaces of the legs, the sides, and at least the proxtmal one-helf of the tall have black opote maller in else than those of the doreum. Generally, the spotting on the sides stops at the level of the insertion of the lege. With some specimens, fine opotting continues down the sides and onto the venter. With few exceptions the underourfeces of the lage and tall are imaculete. There is apparent correlation between degree of darknese and spotting of the dorsum and the degree of spotting of the venter. All opecimens in this sertes heve what I consider black chins, bleck-tipped toes, and whitiah spots around the snout. These three charecters are presumably charecteristic of $\underline{\underline{P}}$. E. schenck1. Thirty-one specimens have been designated as $\underline{\text { P. }}$. . ruber on the besis of the following criteria: ground color purplieh-brown; spots fused and of irregular sizes; secondary spotting on dorsum provelnent; venter spotted; chin with black spots; in preservetive, the 
dorsel color darker than that of venter. IIve specimena have been des1gnated es E. I. schencks on the basis of the following exiter1e: total length less than $130 \mathrm{~mm}$.; ground color not purplish-brown; spots distInct, not fused; no secondary spottIng on dorøum; venter unapotted; chln solld bleck; dorsal color not dlstinct from ventral color in preservative. Five opecinens have been designated as I. I. ruber $\times$ schenckl Intergredes by possessing verlous combinatione of the characters of each of the subspecies.

B1shop (1947: 390) Implles in his map of the distribution of the subspeclas of $\underline{\underline{P}}$. ruber that $\underline{\underline{P}}$. $\underline{z}$. schencks occuples the high mountelns along the southeastarn border of Tennessed. Ixanination of the respective distributions of the specimens I have asaigned to g. $\underline{\text { g. ruber }}$ and P. $\underline{z}$. schencks shows an Intaresting pettern (F1g. 12). The I. I. sehencks assignees are from elevetions of 900 feet in the Valley and from 2,100 feet in the Unakas. Geographically and eltitudinally these specl-

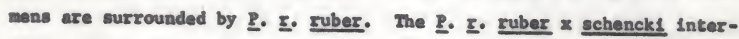
gredas are from alavations of 900 feet in the Velley and fron 1,500 and 2,500 feet In the Unakas. One 1nference is that g. I. schencks is a lowland form which can occur at high eltitudes where suiteble habitate exist. Dunn (1926: 284) states that ‥ E. schenckf "Reaches 3,500 feet In the Belsam Mts." I Infer ha means it ascends to 3,500 feet. King (1939: 557) records this salamandar from 5,000 faet in the Graat Smoky Mountains Netional Park. He elso states that $1 \mathrm{t}$ is most abundant at elavations below 3,000 faet. Anothar Inference 1s that the $\underline{\underline{P}}$. ruber population on the western slope of the Unakas 18 an Intargradient one between I. I. ruber and I. I. schenck1. Alb, It may be that specimens 
I have designated as E. I. schencks end P. . . ruber $x$ schencks intergredes may be individuals exhibiting various stages in the ontogenetic development of edult $\underline{\text { P. }}$. ruber coloret1on. I feel that diatinguishIng between these forms is highly subjective and Indicative of the need for a thorough revialon of the $\mathrm{P}$. ruber complex.

Wone of these specimens is referable to .. I. nltidus.

Two apecimene remaln to be discussed. These are two femsles;

on from thee County and one from Monroe County. The dorsun of the head, body, and tall to Its tip is covered with large black spote and blotehes, whlch suggest a herring-bone pettern. The ent1re ventral surfaces, except those of the legs in the Honroe County specimen and of the tall in the Rhea County specimen, are profusely covered with susll bleck spots. The spots on the chin and gular regions are the largest. The margin of the upper Jaw is barred with black. The tmargin of the lower Jaw is black. Whitish spote are present around the snout.

Comparison of these two specimens wh a serine of P. I. vioseat from Tuscaloose, Alabana, in the Untversity of Florida Collections discloses differences between these specimens and the Tennessee specimens. Firat, the Tennessee specimens leck the midventrel concentretion of spots suggesting e IInear series. Second, the spots on these specimens are wore profuse and more clearly defined than those of the Alebema specimens. These two Individuals are considered es $\underline{\text { g. }}$. . ruber $x$ vloscal Intergrades. The collection of one of these in thee County tends to negate the suggestion of Mitleman (1946: 2) that this river is a barrier to the distribution of P. I. vioscal. 
S1tuations in which Pseudotriton have been encountered range from beneath logs in relatively rerophytic second-growth oak and oakpine forest, to edification situations in woodland, to spring-boll pools. They are most frequentiy found in apring seepage areas in woodland. The

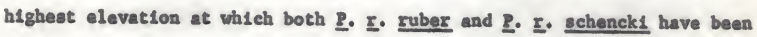
encountered is 5,000 feet. The two designated as $\underline{\text { P. }}$. ruber $\times$ vioscal Intergredes are from 1,900 feet in thea county and 2,000 feet in Nonroe County.

Genus Aneides, Climbing salamanders. Aside from one additional locality record (Fig. 13), I can add nothing to the knowleage of the Green Salemander, Aneldes seneus (Cope and Backard), that has not been reported by Gordon (1952). The two specimens, both males, do not differ from the description of this specles as glven by B1shop (1947: 328332).

Genus Euryces, Brook Salananders. This genus is represented in eastern Tennessee by three species: Two-11ned salamanders, Burycen blsllneate; Long-talled Salamanders, Eurycea longleauda; Ceve Salananders, Euryces luclfuge (Figs. 13 and 14 ).

$81 x$ spectmans ( 4 ferales, 2 males) are 1dent1f1ed as the southern Two-11ned 8alamander, Eurycea b. clrrigers (Green). These range in total length (snout-vent length measured to the anterfor border of the vent in parentheses) from $75 \mathrm{~mm}$. (36 m.) to $101 \mathrm{~mm}$. (47 m.). The largest female is $101 \mathrm{~m}$. (47 m.); the largest snout-vent length among males is $47 \mathrm{~m}$. The tall of this specinen 1s incomplete.

These specimens agree with description of $\mathrm{g}$. ‥ clrrigere as given by Mittleman (1949: 90-91) es follows: 14 costal grooves; dark 


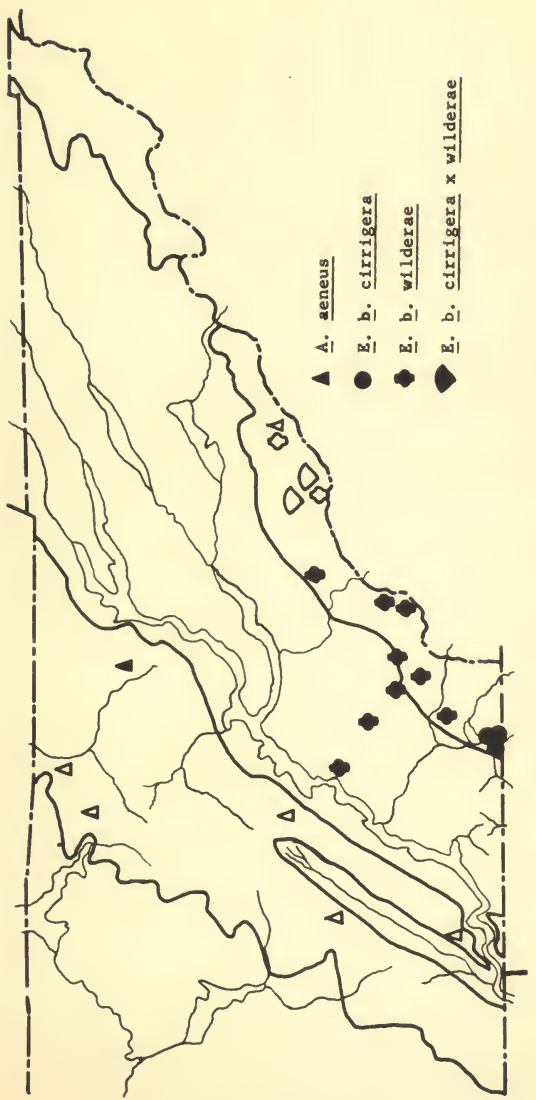

於

ํㅗㄴ

4

离

竎

뭉

密

苞

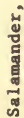

ฮี

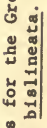

势

글 객

3

is

i

$\rightarrow$ 라

我粂

马̆ 


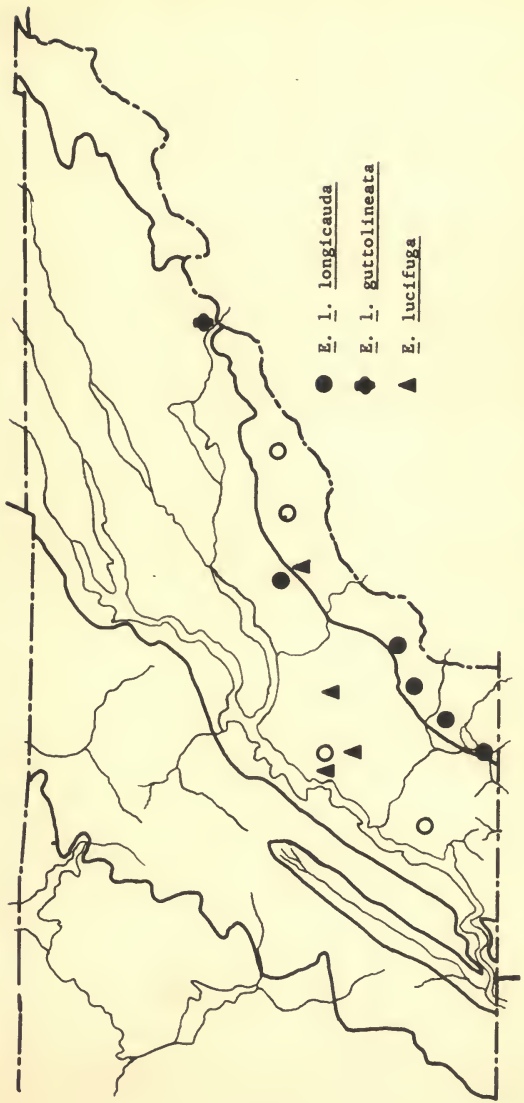

ఫ్ఫే|

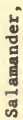

चै

론

4ै

ฮี

क्षा

㟧

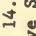

so

i.

뭉 
brown dorsoleterel 11 nes extending to the tip of the tail; a row of white spots on the sides ebove the level of the legs; males with prominent cirr1. The females have three costel folds between the appressed 11mbs. One of the males, snout-vent leagth $40 \mathrm{~mm}$, hes the toes of the appressed 1 imbs meating. The other male, snout-vent length $36 \mathrm{mw}$., has one costel fold between eppressed limbs. These specimans are quite distinct from e series of the Mdwest Two-11ned salanander, suryces b. rivleole Mittleman, from Ohio. They do not appear different from serles of E. b. clerigere from Florida.

All of these six apecimans are frow the Unake Province in extreme southeestern Tennessee but from elevetions of 900 to 1000 feet (Fig. 13).

Sixty-three opecimens of $\mathrm{E}$. blelineate are identified os the Blue Ridge Salamander, Buryces b. villeree Dunn. They are like this subspecles es defined by Mittleman (1949: 91): distinct bleck dorsoleterel lines not tending to blend with leterel pigmentation; dorsoleterel I1nes do not extend uninterruptedly beyond the besel one-third of the teil; males possess cirr1. Among 11 females, the frequency of number of costel folds between eppressed $11 \mathrm{mb}$ is es follows: two on five specimens; three on flve opecimens; four on one opecimen. Among 15 males, the frequency of number of costel folds between appressed limbs is es follows: One in ten specimens; two in four specimens; three in one spectmen. These date suggest a greeter number of costel folds between eppreswed 1 imbs in females than in males.

Among these 63 specimens, eltitudinal variation is evident in the number of costel grooves. Iventy specimens have counts of 14 
grooves on each side; 36 opecimens have 15 grooves on each side; two specimens have 16 grooves on each side. Tive specimens have counts of 14/15, 15/16, or are not countable. These last five opecimens are from altes ranging in elevation from 2,100 to 5,400 feet. The vertical distribution of the 58 apecimens with equal numbers of costal grooves on each side are at follows:

\begin{tabular}{crrr} 
Blevation & \multicolumn{3}{c}{ Costal Grooves } \\
& 14 & \multicolumn{1}{c}{15} & 16 \\
\hline \hline Below 2,100 feet & 19 & 3 & 0 \\
Above 2,100 feet & 1 & 33 & 2
\end{tabular}

Highton has informed me that the relationship of the number of cootal groove to the number of vertebre appears to be the eame in Burycea as in Plethodon. Thus, opeelmens with 14 costal grooves have 15 trunk vertebra, those with 15 grooves have 16 trunk vertebra, and those whth 16 grooves have 17 vertebrae. Until 1 it is deternined whether or not these variations in numbers of costal grooves are genetically or enviromentally controlled, it is decaed desirable not to give nominal recognition to the lowland population of $\underline{\mathrm{E}}$. $\underline{\mathrm{b}}$. vildereg.

Among the meles in this series of 63 specimans, some are wore orange and have more profuse spotting of the middorsal band than others. Males of this kind are more frequent from elevations above 2,000 feet. Ineluded among locelities for the subspecles of $\mathrm{g}$. blalineats In Figure 13 are two for $\underline{\text { g. }}$ b. clrrigera $x$ vilderee intergrades. These records are from King (1939; 557). Fighteen salemanders (10 females, 8 meles) are identified as the Long-talled Selenender, Eurycee 1. 1onglequda (Green). These range 
In total lengths (snout-vant lengths in paretheses) fron $100 \mathrm{~mm}$. (50 mm.) to $163 \mathrm{~mm}$. (65 m.). The number of costal grooves ranges from 14 (12 specimens) to 15 (two specimens) on each s1de. Two specimens have counts of 13/14, two have counts of 14/15. Although the value of tooth counts is suspect, they are Included hare for completeness. Vonerine teeth vary from $16(10 / 6)$ to $36(18 / 18)$, mean $21(12.6 / 11.3)$. Date for the parasphenold teeth are as follows: parallel in 11 specimens, divergent posteriorly in seven specimens; separated frow each other by the wldth of the choanae in elght specimens, by greater than the width of the choanae in three specimens, by less than the choanal width in six specinens; separated from the vomerine teeth in terms of width of the choance from 1.5 to 6.0 times, mean 1.2 .8 times choanal width. The proportion of the totel length attributable to the tall ranges from 50 per cent to 61.8 per ceat, aean 57.7 per cent in the meles and from 55.4 per cent to 64.9 per cent, wean 59.9 per cent in the fenales. Ratios of hesd dimensions into snout-vent lengths are as follows: femeles, snout-vent length/head width from 6.3 to 8.9 , mean 6.4 , snoutvent length/head length from 4.5 to 6.2 , mean 4.6 ; males, snout-vent length/head width from 6.4 to 7.7 , wean 7.7 , snout-vent length/head length from 4.5 to 5.3 , wean 4.9. These meristic characters are apparently Intermodiate between E. L. Longlenude and the Mdland Long-talled Salamender, Burycee longlcaude pernix Mittleman, and in coloration these 18 spectmens are not different from E. 1. longlceude.

This selamander 1s infrequently encountared (Fig. 14). collection sites range from the twilight zones of caves to beneath boards 
near apring seeps in pastures. It seens to be confined to deciduous or donalnently declduoue forest. The highest elevation from which it is known 18 2,500 feet.

Two male apectmens of the Three-1Ined Salamander, Eurycee 1. guttolineate (Nolbrook), do not differ from the description of this subspecies as given by Brshop (1947: 425-427). One spectmen is 160 an. In totel length, $54 \mathrm{~m}$. In snout-vent length. The other has an incomplete te11. Its snout-vent length is $62 \mathrm{man}$. Both heve 14 costel grooves and a serles of 20 vomerine teeth. The paresphenoid teeth rows are parallel and separeted from the vowarine serles by four times and by 2.8 times the diameter of the choanas. The parasphenold teeth rows are separeted from each other by one-helf and one times the dianoter of the choanae. These two specimens are from Peint Greek, Green County. The collection site 18 one and three-quarter elr miles northeast of the confluence of Palnt Creek with the Irench Broed RIVer (F18. 14). The elevetion is 1,400 feet. Both specimens were collected et night as they were prowling ebout the edge of the creek. This is the northernmost known locality for this salamander on the west side of the Appalechien Mountelns.

The Cave Selamander, Eurycee lucifuge (Rafinesque), is represented by five female specimens. These range in totel length (snoutvent length in paretheses) from $135 \mathrm{~mm}$. (59 m.) to $149 \mathrm{ma}$. (64 man.). The longest snout-vent length is $67 \mathrm{~mm}$., but this individuel hes an in. complete tell. Bach has 14 costel grooves. In color these are not different from the description of $\mathrm{B}$. luclfuge es given by Bishop (1947: 434-435). 
All save one of these vere taken in the tullight sone of ceves. The exception 1s one which was taken on the highway lete on reiny night in the vicinity of second growth oakopine forest. No known cave exists in this ares. The highest know elavation for the occurrence of this salamander 161,000 feet. The distribution of thesa specimens is ahown in Figure 14.

\section{Ordar Salientia}

This order is represented in eestern Tennessee by 5 fanllies, 7 genera, end a minimum of 15 species.

\section{Fandly Palobatidae}

Genus Scaphlopus, Spadefoot Toeds. Wright end Wright (1949: 124) do not Include eastern Tennessee within the range of the Bastern Spadefoot Toed, Scaphlopus h. holbrookt (Harlan). Centry (1955: 174) does not record this toad from countles of eastern Tennessee. I have collected this toad fron severel locilities in the Velley Provinca (F1g. 15). As is true in other parts of its range, this toad is infraquently encountered. Ixcept for occasional individuals exposed curing earth moving projects, it is seldom seen or heard at times other than durling the heavy reins of early spring or summer. Ite distribution in eastern Tenneseea seems to be exclusive of the Unake Provinca. I praaume that it will be found in the Cumbarland Plateeu region. The higheat known elevation of occurrence 1s 1,000 faet.

The Vallay population is rapresented by nine female and nine male specimens. The range of body langths respactively is $38 \mathrm{~m}$. to 
60
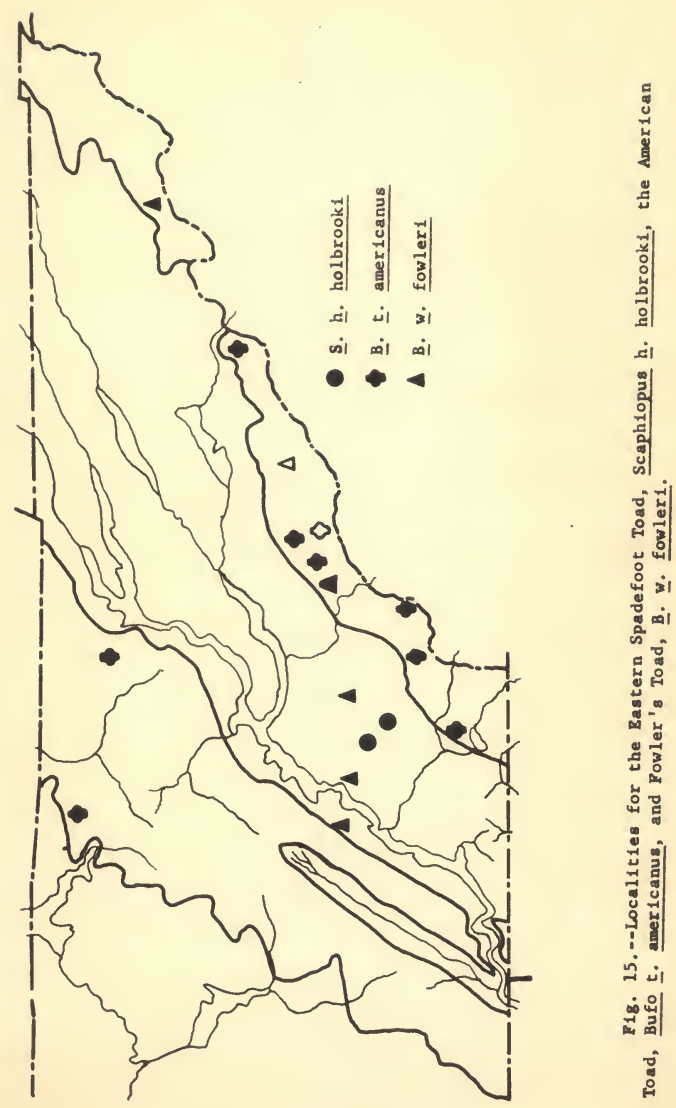
$66 \mathrm{~mm}$, and $35 \mathrm{ma}$. to $70 \mathrm{~mm}$. In other meristic characters, structure, and color these speciment are not different from the description of this toad as given by Walker (1946: 25) and Wright and Wright (1949: 124-126).

Family Bufonidae

Genus Bufo, Toeds. Two forms of this genus occur in eestern Tennessee. They are the American Toed, Bufo terrestris americanus (Holbrook), and Fowlar's Toad, Bufo woodhousel fowler1 (Hinckley) (P1g. 15).

B. t. americanue 18 represented by a series of 12 females and 27 males. The largest body lengths for females and males respectively axe $93 \mathrm{~mm}$. and $79 \mathrm{~mm}$. In their descriptions of this toed, Walker (1946: 28-29) and Wright end Wright (1949: 141-142) report horny excrescences on the becks of the first and second fingers of meles. Wright and Wright (loc. c1t.: 201) record these excrescences on the third finger es well as the first and second fingers of male Southern Toads, Bufo t. terrestris (Bonnaterre). S1xteen of the 27 mele $B$. $\underline{t}$ americanus possess this horny excrescence on the third es well as the first and second fingers. None of the 12 females or 27 males hes the knob-like extensions on the cephalic crests nor the tuberculate parotolds found on B. t. terrestris. Eleven females and meles (including two of the $16 \mathrm{males}$ mentioned above) possess e dark line extending obliquely from above the shoulder to or close to the groin. This line is continuous in some epecimens. In others it becomes broken into derk spots end/or mottled in en oblique IIneer arrangement to the groin. A similar oblique stripe 
18 antioned for B. $\underline{\text { t. }}$ terrestris by Wright and Wright (1bid.). These terrestris-11ke characters may be within the normal range of variation

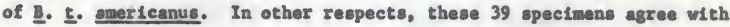
the description of 트. Wright.

B. $\underline{\text {. }}$ fowler 1 is represented by aeries of 15 females and 22 males. The largest body length for females and males respectively is $71 \mathrm{~mm}$. and $68 \mathrm{men}$. Except for several specimens, this serles of toads agrees with the description of B. ․․ fovlerf as given by Carr and Goin (1955), Walker (1946: 34-35), and Wright and Wright (1949: 211-212).

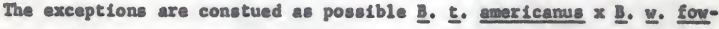
leri hybrids.

There are two such specimens, both females. Each has several warts on the tibiae much larger than those on the tarsi. Bach also has intensively speckled abdomens. These two criteria are used to distin-

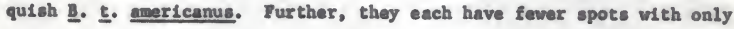
one wart than other opecimens in the series of B. $\mathrm{y}$. fowler1. Neither has cranlal crests suve for falnt suggestions of the supraorbital creats. The lack of these crests, plus the occurrence of spots with as many as four warts each, is condiered as B. ‥ fohlert characters. Of the 39 specimens of B. $\underline{\text { t }}$ emericanus, only two possess this many warts per spot,

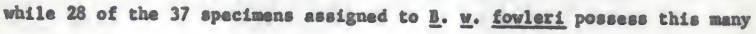
warts per spot.

Walker and Wright and Wright give the following criterla to distinguiah B. ‥ emericanus from ‥ ‥ fovler1. As is evident from the 
data, the differences are more of a quantitative than of a quelltetive nature.

B. ‥ terreetris

Postorbitel crest extend-

Ing in short spur to an-

terior edge of parotold.

Parotolds distinctly sepereted from postorbitel erests.

Large dorsal warts; one or two warte In each dark epot.

Some warts of tibla wuch larger than varts on tarsus and foot.

Ventral surfece ugually nottled with bleck or dark brown.

Tibiel length in edults 35 to 42 per cent of body length.
B. v. fowler1

Postorbitel crest without short spurlike projection.

Parotolds frequently in contact with postorbitel crests.

Small uniforn dorsel werts; usually several warte per spot.

Warte on the tibla 11ttle larger than those of tareus and foot.

Ventral surfece usually unmottled or with a central dark spot.

Tibial length in edulte 38 to 48 per cent of body length.

Comparing the above eriterie with the descriptions of the two specimens speculated as being hybrid Individuals eaphesizes their Intermedlate nature. Further, the tiblal length 1838 per cent and 40 per cent of the body length in these two opecimens. It is quite possible that eech of these two specimens 18 merely an extreme variant within the range of varietion of elther of the subspecies. Suffielent date ere unaveilable et present for further speculetion.

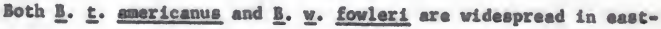
ern Tennessee (F18. 15). But the formar is not known by me to occur In 
the Valley and occurs at higher elevations than the latter. Known maximus elevations of occurrence for B. ‥ amerlcanus and B. w. fowlert respectively are 6,000 feet and 2,500 feet. The two specimens discussed as possible hybrids are from an elevation of 3,500 feet and were taken In association with B. $\underline{\text {. }}$ mericanus. It Is of interest to note that while specimens of $\mathrm{B}$. $\underline{t}$. amerlcanus-ware collected at elevations es low as 1,000 feet (Kiasel Spring, Blount County), none vas taken in the phystographically defined Valley Province. Conversely, B. ‥ fowlerl seems to be confined to elevations of 2,500 feet or 1ess, even in the physlographically defined Unaka and Cumberland Plateau provinces. King (1939: 565) reports a specimen of ․․ ㄸ. forlert from 4,000 feet in the Great Smoky Wountains Mational Park, but speaks of 1ts occurrence above 3,000 feet as sporadic. Thus, B. E. amer1canus ia eastern Tennessee seens to be an upland form and S. ‥ fouler 1 seeme to be 0 lowland form.

Fandly Hyl1dae

Genus Acris, Cricket Froge. Although represented by only 19 specimens of undetermined sex, the Cricket Frog, Acris gryllus, is quite abundant along the shorelines of ponds, Tennessee Valley Authorfty Impoundments, and low banks of and marshy arees adjacent to streams in the Valley and Cumberland proviaces (Fig. 16). This frog is seldom encountered in woodlands. The highest elevation from which this frog is known 18 1,800 feet atop the vestern escarpment of the Unaka Province. The site is an artificial lake with outlet streams descending into the Valley. The range of body lengthe of this series is within that given for the Northern Gricket Frog, Acris gryllus crepitans (Baird), by 
65
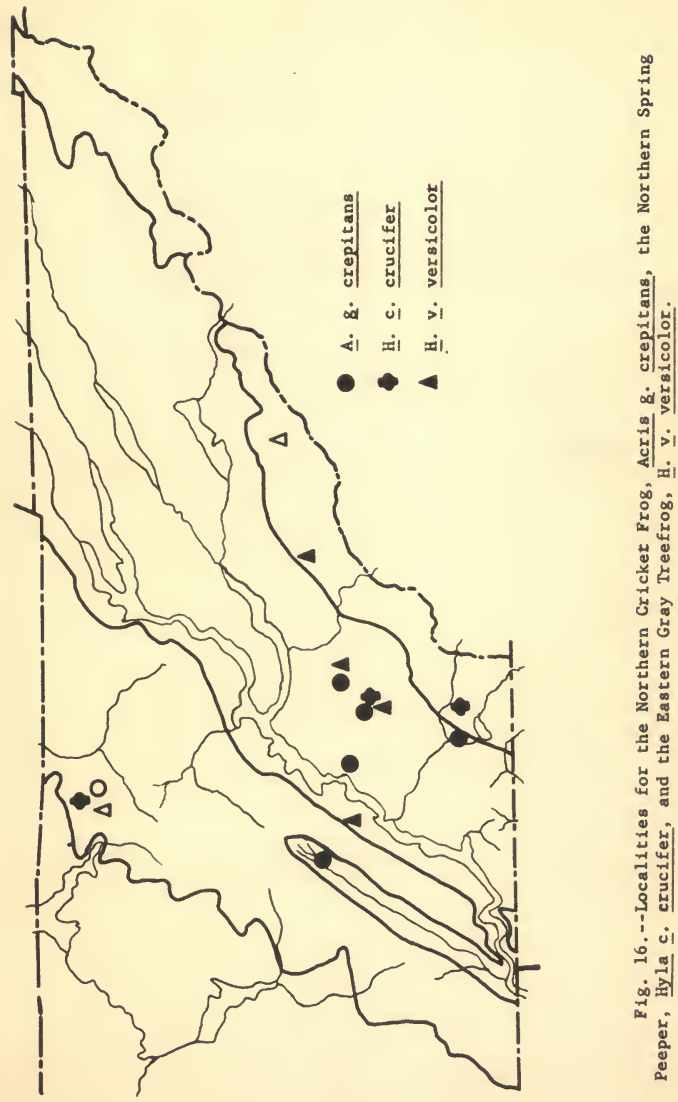
Wright and Wright (1949: 223). The body lengths range from $22 \mathrm{~mm}$. to 26 m. In using the character "extent of webbing" I have used the distal termination of the wob on the phalanx. As regards Dunn's characters (Wright and Wright, 1949: 223) for distinguighing A. B. crepitans from the Southern Cricket Frog, Acr1s B. gryllus (LaConte), these 19 spec1mass agree in amount of webbing with $\mathbf{A}$. $\mathrm{g}$. crepltans. However, in a few specimens, the cermination of the web on the first toe is short of the distal tip by one-half the length of the terminal phalanx, suggestIng the condition in A. B. gryllus. The width of the head across the base of the lower Jaw is one to two millimeters greater than the dis. tance from that point to the tip of the snout. This is an $A$. B. crepitans character. Further structural characters of $\mathbf{A}$. $\mathrm{g}$. crepitans possessed by these specimens are as follows: all but three have two subanal warts consplcuous because of color and structure; the heel of the exo tended 1 gef all but one does not reach the snout. Thus, on the basis of structure, these specimens way be assigned to the subspecies A. $\mathrm{g}$. crepitans. This is also true as regards the color pattern of the posterfor surface of the thigh.

The 19 specimens were compared with a series of $4 . \mathrm{g}$. gryllus from Alken County, South Caroline. These latter specimens have at least two definite brown stripes separated by a white stripe. Occasional specimens may have a third dark stripe on the dorsal surface of the thigh separated frow the median posterlor brown stripe by a white stripe. The lowermost brown femoral stripe is separated from the mottled venter of the thigh by a whte stripe. The lowermost brown femoral 
stripe is separated from the mottled venter of the thigh by a white stripe. Thus, in rear view, the posterlor surface of the thigh fron top to botton presents alternating whlte-brownwhlte-brown-white stripes; somet ines brown-white-brown-white-brown-white. The 19 Tennessee spec1mens have the following petterns: white-brown-white, the brown stripes are not always distinct and sometimes blending into the lowernost white stripe. Occeslonal spectnens may have a pattern of white-brown-whitebrown stripes. The lowermost brown stripe being a concantration of pigment of the ventral surfece of the thigh.

Genus Hyle, Tree Frogs. This genus of frogs is represented in eastern Tonnessee by two forms: the Northern Spring Peeper, Hyla c. cructfer (Wied), and the Eastern Gray Tree Prog, Hyls v. versteolor (LeConte). Ne1ther of these frogs is represented by nunerous collected specinens. But, these specimens plus call-note Identifications Indicete these frogs are of rather widespread occurrence in at least the Valley Province (R1g. 16). E. c. cruclfer is found as high es 4,000 feet (KIng, 1939: 567). It is charecter1stic of marshy madows and floodplain pools where forests are not dense. This is quite in contrast to the habitat of $\underline{\text { S. }}$. versicolor. This frog seems not attracted to ponds or pools which are not associated with forest. The highest elevetion from which ‥ ‥ versicolor 18 known is 2,500 feet.

‥ c. crucifer 18 represented by series of 3 fenales and 12 males. These range from $28 \mathrm{~mm}$. to $37 \mathrm{~mm}$. In body length. The largest specimen 18 a female. The largest male has a body length of $31 \mathrm{~mm}$. These specimens are not different from the deseription of $\mathrm{H}$. C. cructfer as given by Welker (1946:57-58) and Wright and Wright (1949: 311-313). 
ㅌ. y. versicolor 18 represented by a sertes of one female and $13 \mathrm{males}$. These range $\mathrm{in}$ body lengths from $36 \mathrm{~mm}$. to $45 \mathrm{~mm}$. among the males. The fenale has a body length of $54 \mathrm{~m}$. The range of ratios between body length and third finger length is 5.1 to 7.1 , waen 6.1. This range is greater than that $g$ iven for this frog by Wright and Wright (loc. c1t.: 91). There is a tendency among about half of the specimens to have a sub-circular spot enclosed by the dark reticulations on the posterior surface of the thigh. Such color pattern is wentioned for the Southern Gray Tree Frog, Hyle y. chryeoscelle (Cope). However, this may be within the noreal range of color variation of ㅁ. ‥ verelcolor. Genus Pseudecris, Chorus Frogs. Two specles of chorus frogs are present in castern Tennessee. They are the Mountaln Chorus Frog, Preudacr1s brachyphona (Cope), and the Chorus Frog, Psaudacris nigrite. As will be shown subsequently, the latter is interpreted as an intorgrade population between the subspecies Pseudacris n. ferlarum (Baixd), the Upland Chorus Frog, and Peeudaeris n. Exiseriata (Wied), the Western Chorus Irog.

P. brachyphona is represented by a series of 3 feasales, 20 males, and 22 of undetermined sex. The males range in body length from $25 \mathrm{~mm}$. to $34 \mathrm{~mm}$. The fomales range in body langth from $31 \mathrm{~mm}$. to $37 \mathrm{~m}$. The largeat male and female are larger by three and four millementers respectively than the largeat from Ohlo (Walker, 1946: 47). Among these specinens, 35.5 per cent (16) possess a cross-shaped dorsal pattern. Walker (loc. c1t.: 46) reports a 20 per cent oceurrence of this pattern in the Ohio specimens. Martoff and lluaphreys (1955; 247) report a 
50 per cent oceurrence of this pattern in Georgia specimens. These data suggest a geographlcal gradient of th1s character. Among the remalnder of my specinens, 42.3 per cent (19) possess a dorsal pattern of unconnected crescent-shaped merks, and 22.2 per cent (10) possess dorsal pattern of spots and bars.

Ratios obtained from the sexed 1ndividuals are as follows: tibla length/body length, 0.46 to 0.58 , mean 0.53 ; head wldth/body length 0.32 to 0.37 , mean 0.35 . These differ from ratios reported by Walker for Oh10 specimens as follows: ainimum tibial length/body length ratio of Tennessee specimens 180.03 less than that for Ohlo specimens; minimun head w1dth/body length ratio for Tennessee specimens 180.01 less than that for Oh10 specimens. The maxime of these ratios for Tennessee spec1mens are, reopectivaiy, the same as and 0.02 less than the maxtma for Oh10 epecinens. Presentation of these data in terms of the ratios of Wright and Wright (1949: 230) is as follows: body langth/tibla length, 1.72 to 2.19 , mean 2.06 ; body length/head width, 2.66 to 3.01 , wan 2.98 . These specimens possess larger body length/tibla length ratios than the extremes reported by Wright and Wright. The minimun body length/head whth ratio of these specimens is larger, the maximum ancller, than the extremes of thls ratio reported by Wright and Wright. These data also sugsest geographic variation among populations of $\mathbf{P}$. brachyphona.

2. nigrita is represented by a series of 5 female, 31 anle, and 29 unsexed specimens. Salth and Sulth (1952) designate the eastern Tennessee population of this frog as ‥ ‥ ferlaruan. Critical exanination of the 36 sered Individuals Indicates that the eastern Tennessee population is intermediate between ‥ ‥ feriarum and ‥ ‥ trisertata. 
Saith and Smith (1952: 167, 173) give the following ratio values to distinguish P. ‥ feriarue from B. n. triseriata.

$$
\text { P. I. ferlarum } \quad \text { P. n. triseriate }
$$

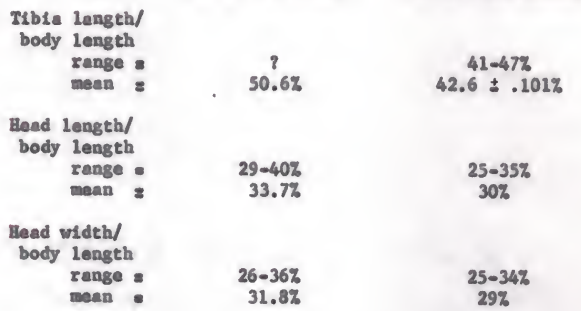

The values of these rat1os obtained from the 36 eastern Tennessee specimens ara as follows: tibla length/body length, 0.43 to 0.51 , wean 0.47 ; head length/body length, 0.28 to 0.35 , mean 0.31 ; head w1dth/body length, 0.30 to 0.35 , mean 0.33. I conclude that, on the bass of these data, the eastern Tennessee population is intermadiate between the two subspecies in regard to these charectars. S1nilarly, the color pattern of the eactern Tennessee population is intermediata between that of $\underline{P}$. D. fertarun and I. B. triserlata. This conelusion is based upon a comparison of these spectmens with a series of $\underline{P}$. $n$. trigeriate fron liarper County, Ranses, and with a sarlas of $\underline{B}$. n. ferlarum from Tuscaloosa, Alabame, In the University of Florida Collections.

Difference in color pattern between the Tonnessee specimens and the Tuscaloosa specimens ara as follows: Tennessee specimens much darker, dorsal stripes less consplcuous; dorsal stripes narrower, more 
Interrupted, and with more irregular border in Tennessee specimans; white IIp stripe bordered below by weh more conopicuous brown stripe In Tennessee spectmens; none of the Tennessee specimens lacks a madian dorsel atripe thet does not elso leck the two lateral stripes, Conparison with the Inasas series is as follows: the dorsal stripas are of about the sane relative widths in the two ser1es; Tennessee specimens darker than the Ransas serles; dark line beneath the white ilp atripe is more conspleuous in the Tennessee series. Thus, fewer color differences exlat between the eastern Tennessee frogs and the Kansas froga than between the Tennessee frogs and the Alabeme froge. The range of elevations of collecting sites where $\underline{P}$. brachyphona is known to oceur in eastern Tennessee is from 900 feet to 1,850 feet. It is epparantly reatricted in its distribution to the Unake Province and to the Cumberland Plateau Province, where it is reported as comnon by Gentry (1955: 175). Martoff end Huaphreys (1955: 247) record this frog from an elevation 2,500 feet on the Cumberland Plateau of Ceorgia. I. brechyphone is apparently absent from the Valley Frovince. The range of elevations of collecting altes for $\underline{P}$. nigrita is from 800 feet to 2,500 feet in the Great Smoky Hountains Mational Park (KIng, 1939: 566). The diatributions of the collecting altes of $\underline{P}$. brachyphone and $\underline{I}$. nigrita are suggestive of ecological differences affecting the distributions of these frogs (F1g. 17).

Although $\underline{P}$. nigrita may be encountered in the Unake Province, It is not abundent at low elevations along strean vallays. Two exceptions are know; King's record for this frog at 2,500 feet at Fighting Creek Gap, and a locality on Starr Mountain In Nonroe County at an 

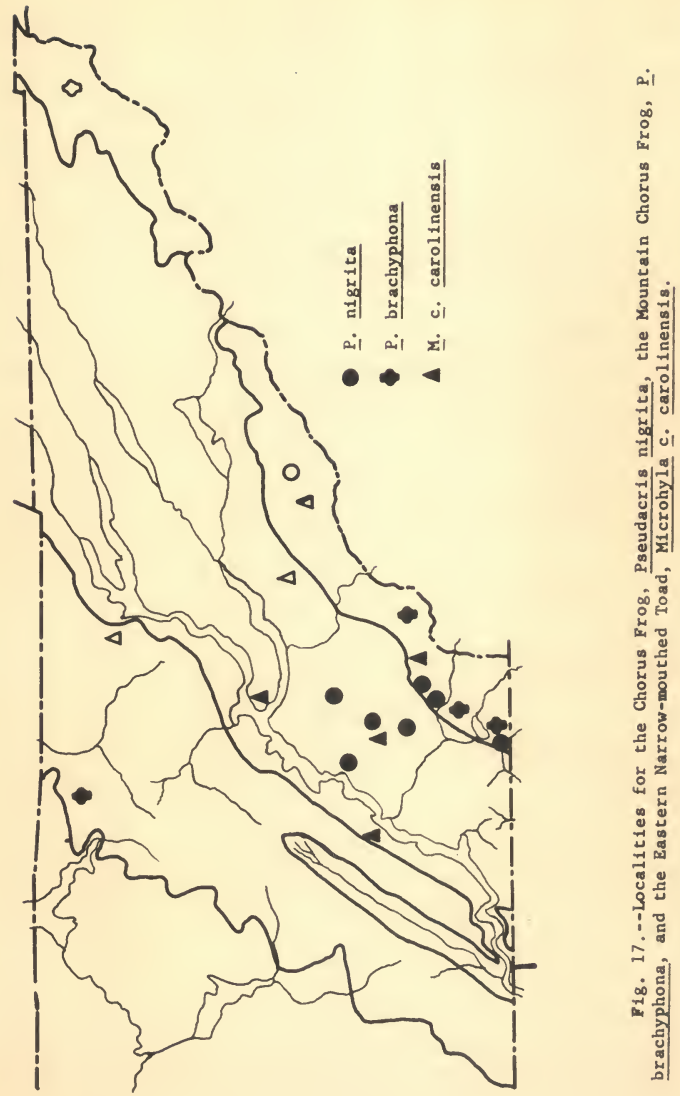
elevation of 1,700 feet. F1ghting Greek Gap 18 accessible from the park headquarters area vithout having to traverse heavily wooded land. The Monroe County a1te is an outlier of the Unaka Province which is separated from the mountains proper by a valley three to Iive iniles wide. Horeover, this valley is rather Intensively farmed. There are wo records of P. brachyphona fron Starr Mountain although it does occur on the mountaln slopes on the east side of the interposed valley. These two frogs have been taken together only in pools of etrean floodplains within the Unaka Province. Thus, while $\underline{P}$. brachyphona may be taken at low elevations, it is always in arese contiguous with the mountalns proper. Conversely, while P. nigrita nay be collected in the Unaka Province, it is only along strean valleys or on mountaln outllers surrounded by valleys. P. brachyphone seems to be restricted to forested lanid, especlally declduous forest. Conversely, $\underline{\text {. }}$ nfgrlta seens to be an Inhabitant of open grasey or glade-type habltats.

Smith and Smith (1952: 178) discuss a hlatus batween the ranges of R. ‥ ferlarum and R. ‥ triserlate from New England southwestward to the Nashville Basin of Tennessee. They attribute this hiatus to the occurrence of $\underline{P}$. brachyphona in th1s region. The implication is that there is Interopecific competition which prevents these two frogs from occurring in the same area. On the basis of the Inforwation presented above, this explanation seems untenable.

Fanily Merohyl1dae.

Genus Mcrohyla, Narrow-mouthed Toads. The Bastern Narrowmouthed Toad, Mcrohyla c. carollnengle (Holbrook), is represented by 
e series of four fensles and eight males. These range in body lengths, respectively, from $19 \mathrm{man}$. to $31 \mathrm{~mm}$. and from $25 \mathrm{~mm}$. to $30 \mathrm{~mm}$. As regards structure and coloration, they are not different from the description es glven by thight and Wright (1949: 571-572).

This secretive toed 18 epparently restricted to elevetions beIow 1,200 feet, elthough it may be found In the physlograpisleelly defined Unake end Cumberlend Pleteeu provinces $(F 1 g, 17)$. It is not found In dense forest, but may be encountered in the edge between forest and field or In cut-over, open timber. Frequently males can be heard cellIng or Individuals may be found et considereble distance froa veter. Next to the bufonids, It is epparently the most tolerent of the sellentlans in estern Tennessee of xeric conditions.

Fandly Ranidas.

Genus Rana, True Frogs. Five specles of this genus oceur in eestern Tennessee. Considered as whole, these frogs are riveled only by Bufo in the variety of end range of elevetion of habitets occupled. The Bullfrog, Rane catesblana Shaw, is represented by six fe* males end 12 males. These agres in ell particulars with the description of this frog es given by Welker (1946: 68-69) and by Wright and Wright (1949: 445-446). The females renge in body length from $43 \mathrm{~mm}$. to $149 \mathrm{man}$, the males from $47 \mathrm{~mm}$. to $132 \mathrm{~km}$.

In areas where ponds are common feature of the landscape, this frog 18 e charecteristc inhabitent of the ponds. In eestern Tennessee, where ponds are of Infrequent occurrence, the Bullfrog is encountered elong the benks of atreams and rlvers end elong the shorelines of the 
Tennessee Valley Authority Impoundants. Th1s frog 1 one of the most commonly encountered ranids in the streams of the Unake Province up to an elevation of 1,800 feet. Locality records Indlcate 14 is of wideapread occurrence in eatern Tennessee (F1g. 18).

The Green Frog, Rane clanitans velanota Latrielle, 18 represented by 6 females, 22 meles, and 4 specimons of undeternined sex. These range in body length froa $27 \mathrm{~mm}$. to $92 \mathrm{~mm}$. The largest wale and female have body lengths of $92 \mathrm{~mm}$. Meriatic data and color variation are within the range of variation as reported by Nechan (MS).

This frog mey be encountered in ponds, along shorelines of impoundaents, In warshy meadows, and along the benks of streans and r1vers. W1th the Bullfrog, the Green Frog is one of the nost frequently encountered ranids in the streame of the Unaka Province. Judging from locallty records, it is of widespread occurrence in eastern Tennessee (F18. 18). The higheat known elevation from which this frog has been collected 1s 3,900 feet (King, 1939: 567).

The Wood Frog, Rana gylvat1ca, 18 represented by seven male specimens. Meristic data from these froge are as follows: body length, $50 \mathrm{~mm}$. to $57 \mathrm{~mm}$.; ratio between tibla length and body leagth, 0.51 to 0.59 , wean 0.57 ; rat1o between head width and body length, 0.33 to 0.35 , mean 0.34 . The mean value of the rat10 between t1bia length and body length of these specimens 18 the same as reported by Walker (1946: 93) for Ohlo specimens of the Northern Wood Frog, Rana gylvatica gylvatica (LeConte). The raisio between head width and body length are within the range of th1s ratio for Ohlo wood frogs. W1tschi (1953) does not present comparable data In his deseription of the Cherokee Wood Frog, Rane 


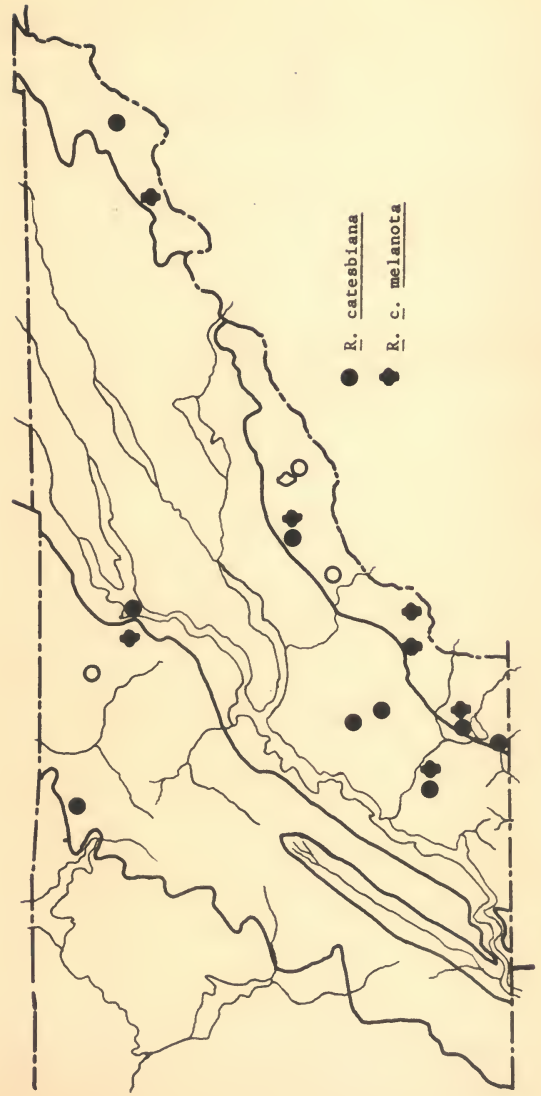


gylvatica cherokiena. The primary distinction between these two frogs seems to be difference in color.

These seven frogs are (and six in 1ife were) wuch darker than Ohio wood frogs which I have seen. These frogs are a dark ollve green on the dorsum. One frog in 11fe was a bright reddish tan. Bxcept for th1s specimen, the masks of these specimens are nearly obscured by the dark dorsal color.

Mr. Robert Humphreys Informs we that the color differences among populations of the wood frog in eastern United Stetes are clinal, making the validity of the subspecies ‥ ‥ cheroktene suspect. Because of the Inadequate type of description of the subspectes and of the few avallable specinens from eastern Tennessee, I an designating the wood frog population of eastern Tennessee as Rana gylvatice subspecies. These seven specimens are from scattered localities (F18. 19). Additional localities Indicated by question marks are whow on the basis of call-note Ident1fications. Mlthough specimens have not been collected In the Valley Province except near the edge of the Unaka ProvInce, breeding choruses have been heard in the middle of the Valley Province (Mclinn County). Invariably these Valley breeding sites have been marshy meadows flooded by late vinter rains. In the forested mountain province egs masses presumably of this frog have been encountered In roadside ditches and floodplain pools. Centry (1955: 176) reports the Wood Frog from Middle Tennessee 200 miles to the west of the Smoky Mountains. He makes no mention as to habitat. Available deta indicate that this frog 18 restricted to elevations below about 2,500 feet, and that it 18 confined to areas in or neax woodland. 


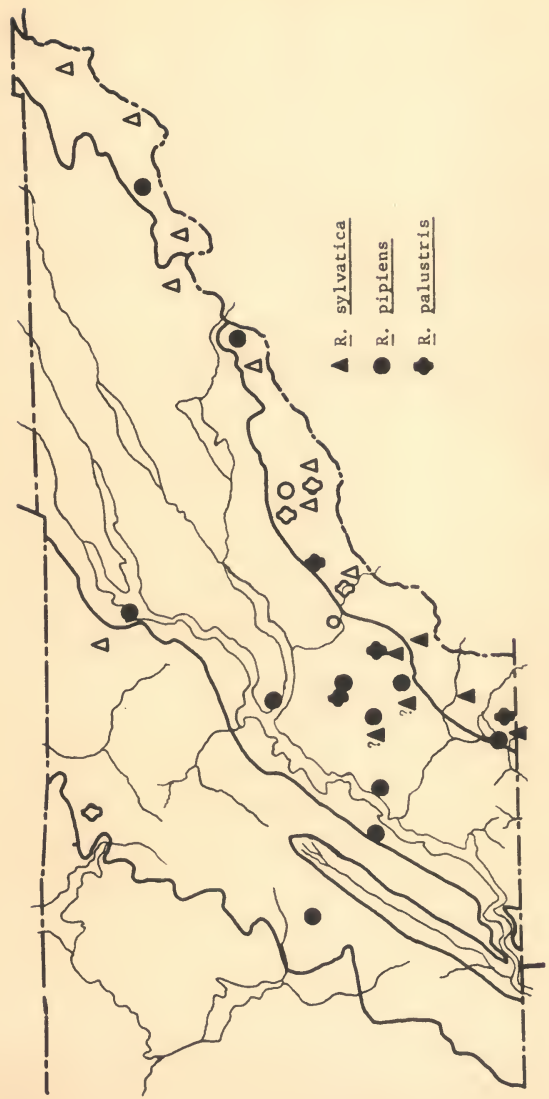

ปี

๙

io 윽

웅

(4)

공

范 :

건

올 금

山

ปี

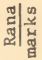

융

出

ㅁํำ

岳

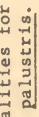

ชู.

व

100

군

i 71 i

$\rightarrow$

ज小

武范

온 
The Leoperd Frog, Rane Plplens, 18 represented by 3 feanales, 5 males, and 5 specimons of undetermined sex. Seven of the 13 opecinens posseas e white tympanic spot cheracterlstle of the Southern Leoperd Frog, Rana R. sphenocephala (Cope). S1x of these lack the rostral epot ascrlbed to the Northern Leopard Frog, Rans R. plplens Schreber Walker, 1946: 87). Of the $1 x$ froge lecking the tympanic spot, only two have the rostrel spot. Three of the specimens with the 11ght tympande opot possess 11ght-bordered dorsal spots es in R. R. Plplens. R. R. plplens 1s described as having distinctly spotted sides below the dorsoleterel IIne; R. R. Iphenocephala is described as having thls aree mottled and or veralculete. Tour of the spectmans with tympanic spots have distinctly spotted sides as do three of the six specimens lacking the tyepanlc spot. The remaindar have mottled end/or vermiculete patterne on the sides.

Maristic date from these opecinens without regard to sex are as follows: body lengthe, $22 \mathrm{~mm}$. to $82 \mathrm{~m}$. (the lergest feasle $76 \mathrm{~mm}$., the largest anle $82 \mathrm{~mm}$.$) ; retio between body length and t1ble length,$ 1.62 to 1.96, mean 1.78; rat10 between body length and snout length, 5.85 to 8.60 , wean 7.17 ; rat1o between body length and upper eyel1d length, 11.4 to 18.6 , mean 13.0. The ret1os between body length and tibla length of these spectmens are within the range given for $\mathbb{R} . \mathrm{R}$. plplens and R. R. ephenocephale; the anximun body length/snout length rat10 is much greater then the maximum reported for elther subspecies, as is the mean ratio of this sar1es; the maximum body length/upper eye11d length ratio is much greater than the analmum reported for efther 
subspecies, but the mean 18 within the range for $\underline{R}$. R. plplens (Wright and Wr1ght, 1949: 102-103). On the basis of these mer1st1c data, and aspecisily on the basis of the intermedlacy of coloration, tha eastern Tannessee populetion of leopard froge is designated as R. R. Plplens $x$ sphenocephale 1ntergrades.

The few specimons of this frog 18 indicative of the infraquency with which this frog is encountered. It is especially uncoumon in the Unaks Province (F18. 19). In the Vallay, where 1 t 18 nore abundant, 1t 18 encountered along strean margins, shorelines of Tennessee Valley Authority Impoundments, and In marshy meadowe. As vumar approaches, It 18 not unusual to flnd this frog in pestures at considerable distance from water. It seen to be character1st1c of grassy conauntes if suffleient wolsture is prasent. It 1 s rarely encountered in forest land. The maximum alevation from whleh it is known is 3,200 feet.

The Plekeral Frog, Rana pelugtr1s Le Conte, is not encountered much wora frequently than the Leopard Frog or the Wood Frog. Only four males and one ferale are avallable as a result of this atudy. These range in body lengths from $55 \mathrm{~mm}$. to $60 \mathrm{man}$. (males). The female has a body length of $67 \mathrm{~m}$. Other data from these spectwans are a follows: rat10 between t1bla length and body length, 0.59 to 0.62 , mean 0.60 ; ratio batween head width and body length, 0.33 to 0.35 , mann 0.34 the head width/body length ratios are within the range reported for Ohlo spacimans by Walker (1946: 80). Tha ulnimun t1bla length/body length rat10 is larger than the maximum for Oh10 specimens. As regards othar structural factures, these five specimens agree wth Oh10 ateriel. 
Generally, thase specimens have color pattarns and coloration as given for this frog by Walker (1946: 80) and Wright and Wright (1949: 478 479). However, cartain diffarences ara rather consplcuous. One mala has a very seall rostral spot, two heve no rostral spot. These latter two frogs have scattered doreal spots of Irragular outline. The sides and uppar surfaces of the lage ara profusely nottlad with bromn. The dark crossbands of the upper surfaces of the $11 m b s$ ara absent on one of thase two males; on the othar specimen they ara present only on the upper surfecas of tha rear 11abs. I do not know whether these color differancas ara within tha range of variation of $\mathrm{R}$. pelustris.

R. Relustris is apparently most abundant in woodad areas. All of the abova specimens are from within or near the Onaka Province (F1g. 19). IIng (1939: 568) raports this frog as occurring by tha thousands In a thrae acre pond on Chetaloochae Craek, Great Snoky Mountains national Park, Haywood County, North Carolina. I have not encounterad an aggregation of this frog in excass of about a doren individuals. Data Indicate that the maximua elevation attained by the Pickerel Frog is around 2,000 seat.

\section{B. Clase Rept111a}

1. Order Chalonta

This order 18 reprasented by 3 fandlies, 7 geners and miniaum of 11 spectas.

Fanily Chelydridaa

Genus Chelydre, Snepping Turtlas. Fifteen feasales, five nsles, and two Individusls of undetarained sex of the Snapping Iurtla, Chelydre 
serpentins, are the basis for designating the eastern Tennessee popuIation as the Common Snapping Turtle, Chelydra 2. serpentina (Linnaeus). All of then agree with the descriptions of this turtle as given by Carr (1952: 63-64).

The snapplng turtle is found throughout eastern Tennessee (Fig. 20). Individunis may be encountered in nearly evory concelvable aguatic situation: wid holes resulting from the aceumulation of raimater; major rivers; mountain brenches; aarshy meadows. The highest elevation recorded for this turtle in eastern Tennesses is 2,200 feet in the Great Smoky Mountalns Mational Park (K1ng, 1939: 578). Pope (1946: 74) states that this turtle occurs at altitudes in excess of 3,000 feat in eastern United states. To my knowledge it is exceeded in altitudinal distribution only by the box turtle. The apparent deterent to the altitudinal distribution of the snapping turtle is the extremaly rocky nature of the streams at high elevations.

\section{Fanily Kinosternides}

Genus Sternotherus, Muk Turtles. Two specles of this genus occur in eastern Tennessee: Sternotherus odoratus and S. pinor. In using the specifle nam minor, I an following the terminology of rinkle and Wobb (1955).

The stinkpot, sternotherus odoratus (Latrielle), is represented by 11 females and 6 males. In $a l l$ respects except two, and these are minor differences, these specimens agree with the description of this turtle as given by Carr (1952: 82-84). The differences are as follows: 14 of these specinens have a black edging on the posterior and postero- 

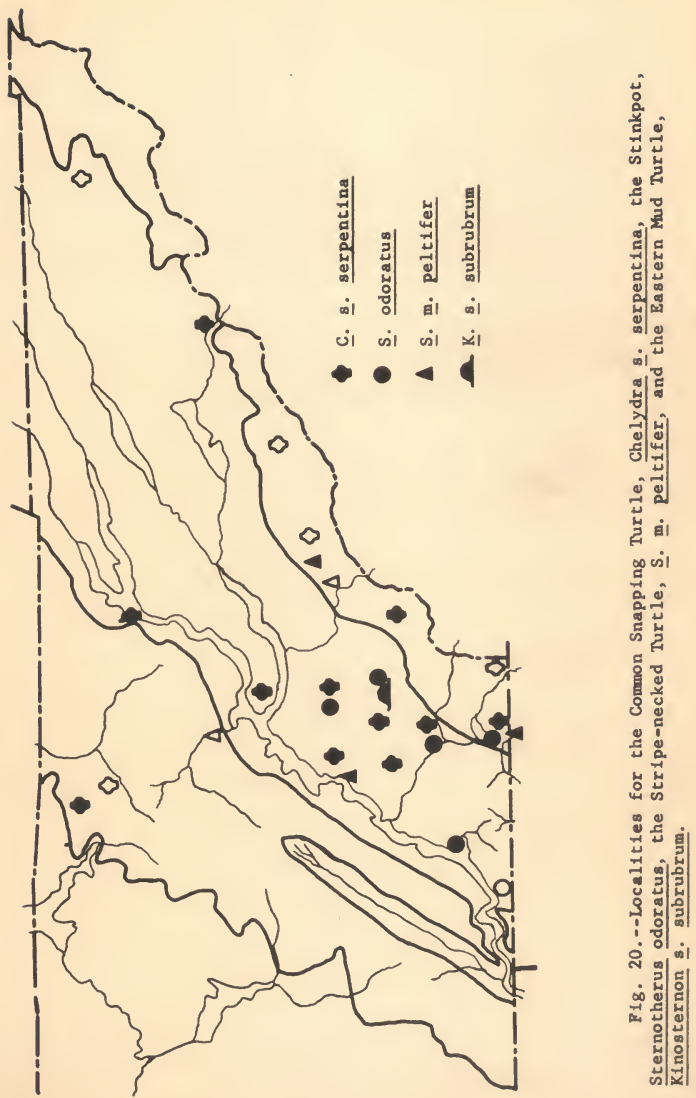
dorsal margins of the lateral lambnae and on the lateral and posterior margins of the central laminae; eight of the specimans have radiating yallowish lines on the first lateral laminee and at least on the ventral portion of the remaining laterals. Carr (1oc. c1t.: 3) states that this turtla has usually an unmarked carapace.

Th1s turtle 18 encountered in stock tanks, rivers, beckwaters of coves, and the lower raeches of the mountaln strenme. It 18 wost common In situations where the botton 18 auddy. Although 1 ts distribution is apparently liefted, I suppect 1t is more widespread than the avallable Information Indicates (Fig. 20). The highest elevation at which this turtle bas been encountared is 1,100 faet.

The Strip-necked Musk Turtla, stornotherus 르. peltifer (Salth and Glass), 1s represanted by 4 females, 6 males, and the shells of 2 Individuals. I could find no apparent discrapancies between thase specimens and the type description (Smith and Glass, 1947). Tinkle (in 11tt.) Informs mat the belleves that the eastern Tennessae population differs from topotypic material. The castorn Tennassea specimens ara " mich flatter and [they bive] more Intense stripes on tha head." Cartain maristic data obtalned from these specimens are as follows: females, carapace length, $46 \mathrm{~mm}$. to $111 \mathrm{~mm}$.; carapace width, $38 \mathrm{~mm}$. to $88 \mathrm{ma}$; plastron length, $29 \mathrm{~mm}$. to $85 \mathrm{~mm}$; and ratio between carapace width and carapace length, 0.70 to 0.83 , man 0.747 ; ratio between bridge width and plastron langth, 0.22 to 0.24 , waan 0.233 ; males, carapace length, $41 \mathrm{man}$. to $100 \mathrm{~mm}$; carapace width, $36 \mathrm{~mm}$. to $69 \mathrm{~mm}$.; plestron leagth, $26 \mathrm{~m}$. to $70 \mathrm{~mm}$; ratio batween carapace width and carapace 
length, 0.66 to 0.73 , mean 0.706 ; ratio between bridge width and plastron length, 0.16 to 0.20 , wean 0.186 . The gular laminae are obviously palred In only two specimens; those of the two smallest opecimans are unpalred. There are euggestions of dark radiating 11 nes on the ventral margins of the first and second costal laminee of four specimens, Including the two amallest. The remaining specimens have costal laminae with dark punctations, occasionally elongated Into dashes and/or short 11nes. These punctations tend to be arranged Into rowe running long1tudinally. The black and the yallow stripes on the doreal half of the neck are of about equal widths. Those on the ventral half of the neck are of different widths; the yellow stripes are up to twice as wide as the black stripes. The teaporal and parletal reglons are narbled and/ or reticulated with black and yellow.

It 18 of Interest to note that s. odoratus and s. ․․ peltifer have not been collected together although they Inhabit the same dralnage eystems (Fig. 20). Trapping in the Tennessec River has resulted in the capture of Peoudemys Graptenys, and s. w. peltiffer at one locallty, but no s. odoratus. Trapping in Sweetwater Greek, Honroe County, has revulted In the capture of Chelydra, Chrysems, and s. odoratus, but no 8. ‥ peltefer. The explanation which seems most acceptable at present, aside from conpetition for food involvas differences in habitat praference.

Mine of the s. ․․․ peltifer specimene are from clear, woderate to owlft, rock and sand botton atreams. Conversely, all but one of the 5. odoratue are from turbid, mud and sand botton streams or ponds. None of the $\mathrm{g}$. $\mathrm{m}$. peltifer 10 from a pond hobitat. It $1 \mathrm{~s}$ posesble that the 
Impoundment of the anjor streams by the Tennessee Valley Authority has decreased the evailability of habitate in those streams auteable for 5. ㅍ. Peltifer and increased the evellability and extent of habitate suitable for $\underline{\mathbf{S}}$. odoretue. The higheat elevetion from which S. 퐁 peltifer is known is 1,500 feet.

Cenus Kinosternon, Mud Turtles. Carr (1952: 101) Indicates the occurrence of the Bestern Mud Turtle, Kinosternon 8. oubrubrum (Lacèpéde), In eastern Tanneesee. Only one specimen, an adult male, is avallable as a reoult of this study. This opectmen is from a marahy pasture, elevation 1,000 feat, in Mckinn County (F1g. 20). Moriotic data from this apecimen are as follows: carapace length, 92 m. $\mathrm{m}$ carepace width, 67 mo; plastron length, 84 an.; width of anterior plastrel 1obe, $45 \mathrm{mn}$.; width of posterior plastral 1obe, 39 man; length of anterfor pleatral lobe, $32 \mathrm{~mm}$; depth of shell, $38 \mathrm{ma}$; widh of bridge, $15 \mathrm{~mm}$.

The upper borders of the marginals are even except for that of the lat anginal, which is roughly triangular and higher by one-third than the highest marginal anterior to 1t. The carapace is rugose (growth rings) and not depressed long the mddorsel region. Mdditionally, two broad lateral ridiges cross the dorsal portions of the lateral laminas one through three. These ridges originate in the region of the birth plate of laterel lemina one and terminate in the region'of the birth plate of lateral lamina three. The lack of a middoreal depressed region and the presence of two leterel keels may indicete this is a bubadult specimen. Ixcept for the above conditions, this opeciman agrees with the description of $\underline{\underline{x}}$. ․․ subrubrum as given by Carr. 
Pandly Buydidae

Genus Terrapene, Box Turtles. Thirty-five females, 29 malas, and 5 specinens of undetarmined sex of the Box Turtla, Terrapene caro11ng, are avalleble. Shell dimanalons of these specimens are as follows: carapace length, $37 \mathrm{man}$. to $140 \mathrm{~mm}$; carapace width, $34 \mathrm{~mm}$. to 119 mo.; plastron length, $34 \mathrm{~mm}$. to $135 \mathrm{~mm}$; depth of shell, $28 \mathrm{~mm}$. to 73 mn. The box turtle population of eastern Tennessee is designated In the 11teratura as the Bastern Box Turtle, Terrapene c. caroline (Linnaeus). Hovever, the ranga of vartation in color and shell conEiguration among my epecimens is euch as to Include almost all the combinations of charactars used to distinguish the four subspectas of this turtle in castern Unfted Statas. The varlabllity of these 69 apacimens Is so great as to almost preclude group description.

Comparison of these spectmens wth selected examples of the Gulf Coast Box Turtla, Terrapene C. pafor (Agessiz), tha Thrae-toed Box turt1a, Terrapene c. triunguis (Agessis), and with I. c. caroline $\times$ triunguls and I. c. caroling $x$ astor Intergrades in the Untversity of Plortda Collections does 11tele to clarify the situation. The head, 11mb, carepace, plastron color pattarns, and the shell configurations of thase selected exanples cen be duplicated in the 69 specimans from eastern Tennessea. Fully one-thlrd to one-half of these 69 specimans possessed one or more of the diagnostic charactars of each of the subspecias other than I. E. carolins. Bven the color pattarn characteristic of the carapace of the Floride Box Turtle, Terrapene c. baurl Taylor, is present. The only subspecific character not axhlbitad by any of these apectmens Is the three-toed condition of I. C. Eriunguis and I. c. baurf. 
Most of the 69 apecimens have varying degrees of the characters attrtbuted to I. c. caroling. A number of the specimens possess a comblnation of an elongate carapace with a diatinetly flared posterior margIn and a daxk horn-colored to black carapace and plastron as described for I. c. Safor. Sevaral apecimens have the head and neck marbled and/ or reticulated with orange or yellow and the anterfor surface of the forelimbs with mumarous amall orange or yellow spots as described for I. c. trfunguls. Most of these opecimens are from the southeastern corner (Polk County) of the study area. These date suggest the possibility that the range of variation In I. ‥ carolins may be such as to Include various combinations of the characters used to diagnose the subspacies

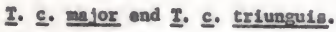

The box turtle 1s one of the most ublquitous reptiles in eastern Tennessee. It is widespread and may be ancountered in all kinds of situations (F18. 21). Aslde from sayling that it is most abundant in forested situations, little can be said about hebitat preforence. It may be found in residential ereas in towns, plowed llelds, along stream margins, and in dense forest. The higheat elevation at which it is known to occur $18 \mathrm{4}, 000$ feet. Th1s turtle and the snapping turtle are the only two which are known among the Copper Basin Inhabitants (Ash, 1945: 265).

Genus Graptemys, Map Turtles. Two spectes of this genus oceur In eastern Tennessee. The Map Turt1e, Graptemg geographics (LeSueur), 10 reported by Carr (1952: 192), Gentry (1955: 331), and Rhoads (1895). I have not encountered this turtle during this study. The other is the 


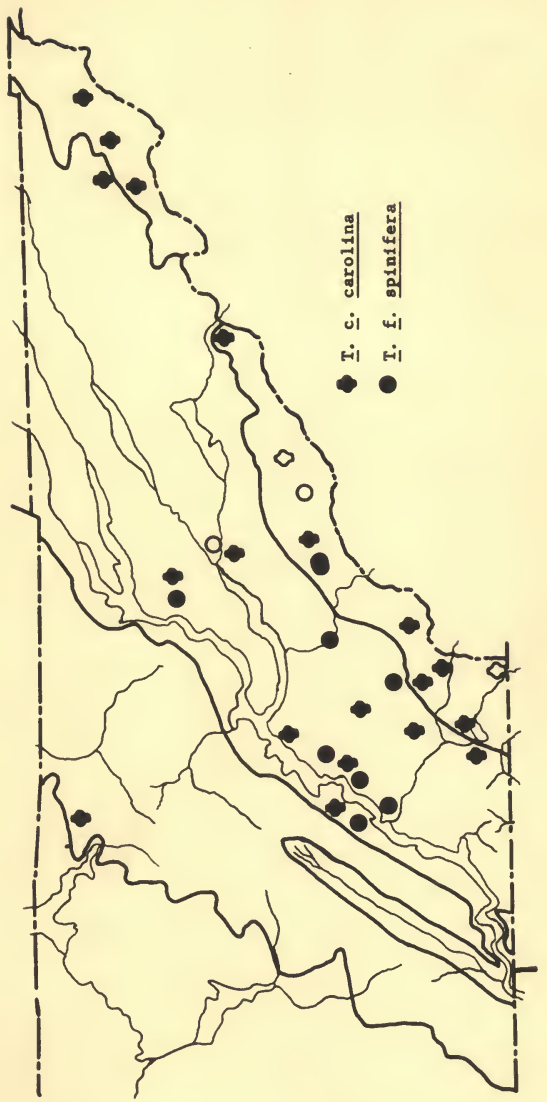

్ㅗㅇ

ن)

혐

है

ณํํํ

㟧

분

! -

츨 出 $\rightarrow$ i

है 
Orachita Map Turtle, Graptenys preudogeographica ouachitensis Cagle. Two spectmens, both Juveniles, of G. R. ouachitensis are avallable fros the Teanessee River In Melgs County (F1g. 22). Thesa agree in all particulars with the description of juveniles as given by Cagle (1953: 11-12). Cagle tentatively Identified specimens from Humphreys County in Middle Tennessee as Intergredes between G. R. ouch1tens1s and the False Map Jurtle, Graptemye R. pseudogeographica (Gray). No ladication of G. R. psaudogeographles influence is present In these specimens. These specimens extend the known range of G. R. ouachltenels nearly 400 miles upstrean in the Tennessee River.

Genus Chrysenys, Palnted Turtles. As previously reported (Johnson, 1954), the peinted turtle population of eastern Tennessee 1s Intermediate between the Bastern Painted Murtle, Chrysengs R. Plete (Schnelder), and the Whdland Palnted Turtle, Chrysemge R. marginate (Agassis). Since publication of the sbove report, 54 additional spec1mens are avallable. These additional specimens are also Intergrades and make It evident that the entire Tennessee River Valley fros Chattenooge to as far north as the Nollchucky River is in the area of intergradation (Fig. 22).

Th1s turtle 1nhabits all permanent types of aquatic situations except the sulft, rocky streams of the mountalns and emall, shallow streams and branches of mountain and lowland. The one requisite for a sultable habitat seems to be a minimua depth of three or:more feet of water. Th1s is the turtle of stock tanks and flooded quarries to which refarence is made as "hard-shelled water terraplns." Although the 


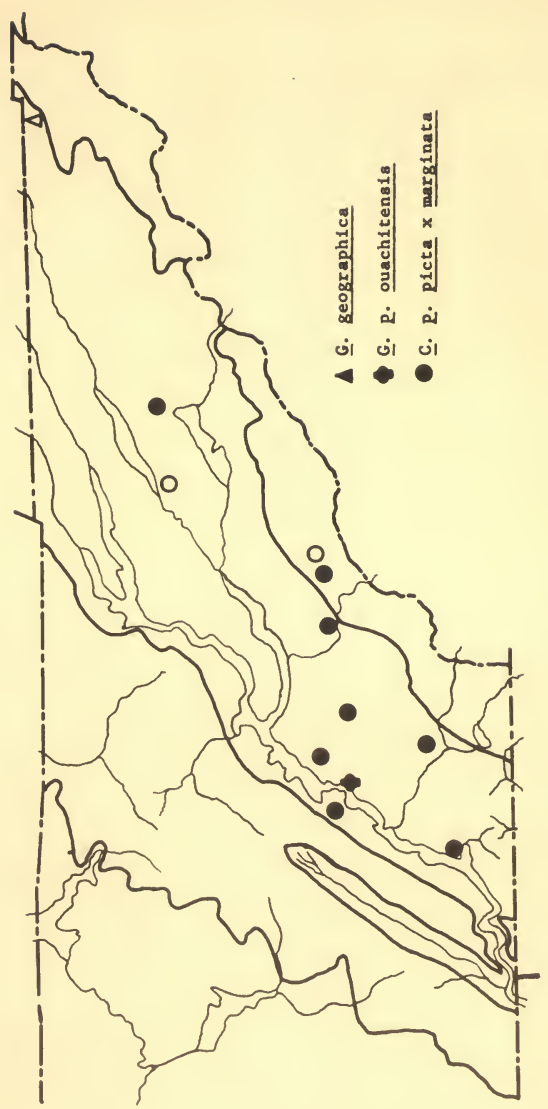

ن

嵌

운

ज्ञ

趈

ํㅟㅎ

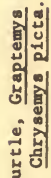

द्वे

ค.

需

อ द्व

I뇸

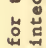

(4)

击

$\stackrel{5}{4}$

홍

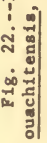

a 
genus Chrysemss is generally considered a pond-type turtle, it is edept at survivel in stream environs. The h1ghest known elevation of occurrence 1s 1,750 feet.

Gonus Peeudemys, Cooters and s1iders. This group of turtles 18 represented by two species: Cootar, Peaudemye florldana; Pond sl1der, Perudangs scripte. Avallable data Indicate that each of these species 1s represented by two subspecies which Intargrade in eastern Iennessee.

$81 x$ apecimens of the Cooter, Preudengs floridans, are the basis for the following remarics. These are from the Consangs Rver, elevetion 1,000 feet, in extreme southeastern Tensessee (F1g. 23). These specimans are four foanles and two males. Maristic data fron the females are as follows: carapace leagthe, 242 m. to 303 m.; carapace wdithe, $173 \mathrm{~m}$. to $187 \mathrm{~mm}$.; plaetron lengths, $218 \mathrm{~m}$. to $286 \mathrm{man}$. ; depth of shells, $78 \mathrm{~m}$. to $103 \mathrm{~mm}$. : retio between carapace length and carapace wldth, 1.39 to 1.46 , mean 1.26; rat10 between carapace length and shell depth, 2.75 to 3.10 , mean 2.91. Morist1c data from the males are as follows: carapace lengths, 197 and $230 \mathrm{~mm}$; carapace w1dths, $145 \mathrm{~mm}$. and $160 \mathrm{man}$; plastron lengths, $176 \mathrm{man}$. and $207 \mathrm{~mm}$; depths of she11s, $63 \mathrm{~m}$. and $70 \mathrm{~mm}$, r ratio between carapace leagth and carapace width, 1.36 and 3.20; rat10 between carapace length and shell depth, 3.12 and 3.29. These date are equally applicable to the River Cootar, Pseudarys E. concinns (LeConte), and the s11dar, Psouderys \&. helroslyphice (Holbrook) (vide Carx, 1952: 287, 305).

Ray characters separating these two aubspecies are alveolar surfaces of the lower jaw, color of hind feat and upper surface of tall 


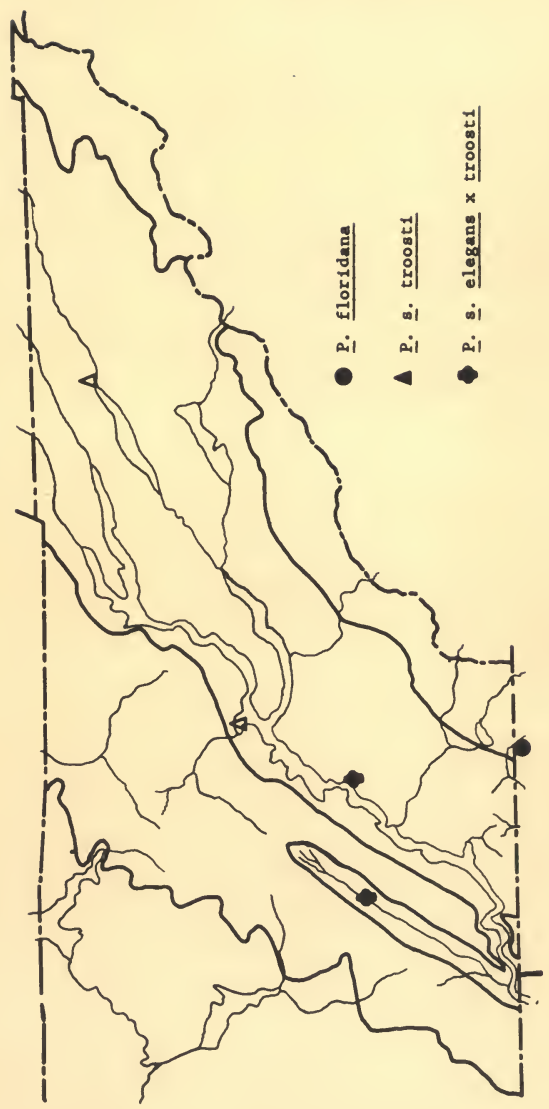

हี

क्ष్: 
(Carx, 1952: 237). On the basis of these key characters, the s1x specimens can be identified as $\underline{\underline{p}}$. E. heiroglyphicas broad alveolar surfaces with high, 1solated, conicel teeth; tall with a palr of dorsolateral yellow stripeo; leg stripes continued onto the toes. Iach also possesses a Coshaped mark on the second lateral lamina at described for P. E. concinne by Granshaw (MS). In other reapects, the color of the

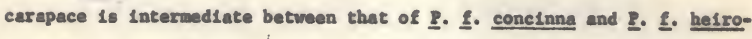
slyphres.

There is no extensive dark central pleatral f1gure. What dark color there is on the yellow plastron is confined to the region of the seans of the various palrs of laminee. These dark areas are best deseribed at snudgee. There are 1ight-centered black spots on the submarg1nal seans fron sean 1-2 through sean 8-9. Poster1or to seem 8-9, the 11 ght center persiste warely as a lighter edge of each of the adjacent laminse or it is absent. On four specimens the blotches at the level of the bridge, or one or two spots anterior to the bridge, are as concentric black rings separated from each other by light-colored rings. The remalning spots on these and on other specimens are colld (except where there may be l1ght central spots as mentloned above). A11 of the epectaens have dark bridge aarkings, In general, as elongate dark blotehes on the lateral edges of the pectoral and abdonsnel laminee. In four of the opecimens, the bridge warkings are in contect whth the submarglnel marks. In one opecinen there is a large dark parenthetical mark (open and directed posteriorly) on the posterlor edge of the abdominal and the anterior edge of the Inguinal laninae. The result 18 two palrs of rather doughnut-shaped anarks on the bridge. 
Each upper marginal lamina is split by a vide verticel bar, T-, or Y-shaped mark. Bach Intermarginal seas is streddled by a group of concentric light rings elternating with dark riags, the latter generally the broeder.

The paramedian head stripes are distinct on all but one of the specimens. On this exceptional specimen, the paranedian stripes join with the supretemporel stripes at the level of the orbit.

Because these specimens exch1b1t morphological and color characters Internadlate between P. E. conclnne and P. E. halroslyphice, I a designating then as I. E. concinna $\times$ heiroglyphlce Intargredes. This places P. . helroglyphlca in the Coose Rivar system of Ceorgla.

The Cumberland Jurtle, Peeudegye 5. troost1 (Blolbrook), is reported from the Great Smoky Hountalns Nat1onel Park (KIng, 1939) and from the upper reaches of the Tennessee River in eastern Tannassee by Carr (1952: 258) and by Burger (1952: 77). I have found no 11terature records of the occurrence of the Red-eared Durtle, Pseudewy s. elegans (W1ed), In eastern Tennessee Waters. Eleven specinens (10 females, 1 male) fron the Tennessee RIver, Malgs County, are evallable and Indicate that I. 5. alegans does occur et leest th1s far north in the Tennessee. River (F18, 23).

Werlatic data from the fenales are follows; carapace length,

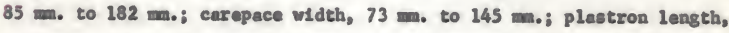
$78 \mathrm{~mm}$. to $179 \mathrm{~mm}$; depth of shell, $38 \mathrm{~mm}$. to $76 \mathrm{~mm}$; rat1o between cerepace length and carepece vidth, 1.17 to 1.28 , mean 1.23 ; ret1o between carapace length and shell depth, 2.27 to 2.71 , aean 2.47. These data 
for the male are as follows: carepece length, 152 m.; carapece width, $118 \mathrm{~mm}$; plastron length, $141 \mathrm{~mm}$; shell depth, 53 mm.; rat10 between carapace length and carepace width, 1.29; ratio between carapace length and: shel1 depth, 2.86 .

Each specimen possesses a reddish or orange spot or wash super1mposed upon a yellow supratemporel stripe. The isupratemporel spot is an average of $3.1 \mathrm{times,}$ range 2.3 to 4.2 times, wider than the contInution of the supratemporal stripe on the necic. These values are Intermedlate between the condition found In P. . troost and P. . elegans, but wore 11ke that of the lattax (Furgar, 1952; 77-79). The supratemporal spot averages 1.3 temes, range 0.8 to $1.8 \mathrm{times,} \mathrm{vider}$ than the subocular stripe, which condition is again Internediete between the two subspecies. The suborbitel stripe is intercepted by the mandibular stripe posterlor to the angle of the Jaws, a condltion reported for R. E. elegans (Carr, 1952: 252).

The bridge of these spectmens is predoninantly light colored. But, a elrcular or elongate black mark 1a present on the seam between edjecent lateral edges of the abdoninel and pectoral laninee in ell but one specimen. This exception has only one bridge opot on the left inw quinal lanine. This is a troosti-like character (Carr, 1952: 260). The submarginal blotches of $s i x$ of the specinens have a single C-ahaped yellow mark on the enterfor half, at least, of the blotch. The submarginsl spots average $1.3 \mathrm{times,}$ range 0.9 to 2.1 times, vider than the yellow Interspaces, a . ‥ elegans character (Burger, 1952: 77). The plestral color ranges from nearly imaculate yellow, as in E. s. troost, 
to yellow with bold black emudges on each of the laminee, as in $\underline{\mathbf{P}}$. $\mathrm{s}$. elegane. Jallow predominates on the front legs, the undersurfaces of the hindlegs, and on the tall as in $\underline{\text {. }}$ s. troost. There is a single yellow stripe on the beak, which is more like the condition in R. S. troost1 than in I. S. elegans.

While it is obvious that troost1-11ke cheracters predontante among these 11 specimans, it is also apparent that elegans-11ke charecters are shared among these specimens. The presence of $\underline{\text { P. S. Elegane }}$ this far up the Tennesses River way be further evidance of range extenslon of this turtle in recent times as euggested by Stejneger (Carr, 1952: 250-251). Porheps the construction of dame across the Tennessee River has increased the sultabllity of thls river at a habltat for this turtle and reduced Its sultability for P. s. troosts. These 11 spectmens were taken in a funnel trap in company with G. R. ouschitensis and 8. 므. peltifer.

Genus Iriongs, Softehell Iuxtles. Only one specles of this genus 18 encountered in eastern Tennessee, vis., the Spiny softshell, Trlonyx ferox. Four apectmens, 3 females and 1 juyenlle of undetermined sex, are evallable. These agree essentielly with the description of the Eastern Spiny Softshell, Irionyz E. spinifere (LeSueur), as given by Carr (1952: 427-428).

While this turtle is represented by only a few specimens, it is not to be assumed uncomion in eastern Tennessee. It is the one most complained about by fishermen as a balt robber. Individuals have been collected and/or seen in both the slower, turbld givers of the Valley 
and the more owlft, clear, and rocky bottom streams of the Unaka Province up to elevations of 1,100 feet (Fig. 21). Field workers of the Tanneasee Iloh and Gerse Cormission floh survey crew tell we it is rathor abundant in such streams as the latter. These workers probably see more of them in these streams because of better visibility. The absence of the Smooth Softshe11, Frionyx mutics (LeSueur), is probably correleted with the relative sbsence of natural ponds in eastern Tennessee. It is concelvable that this turtle my eventually become cetabliehed here as a result of the Tennessee Valley Authority Impoundments, which sinulate habitats sultable for I. mutica.

\section{Order Squamata}

Th1s order is represented by four families, six genera, and et lesst elght species.

\section{Temily Iguentdee}

Genus Anolis, Anoles. The Carolina Anole, Anolls c. carollnensis (Voigt), is represented by four female speclmens. These are from $42 \mathrm{~m}$. to $55 \mathrm{~mm}$. In enout-vent length. They agree with the description of this 11zard as given by Carr and Coln (1955: 254) and by Santh (1946: 95-96).

Th1s 11sard occurs in each of the physiographic provinces contained in the study area (P1g. 24). Habitats in which they have been taken range from the dry oak-pine-heeth comunity of cliff edges on the Plateau to mesic floodplain conmulty at low elevations in the Unaka Frovince. On the basis of sight records and collection sites, the wore 

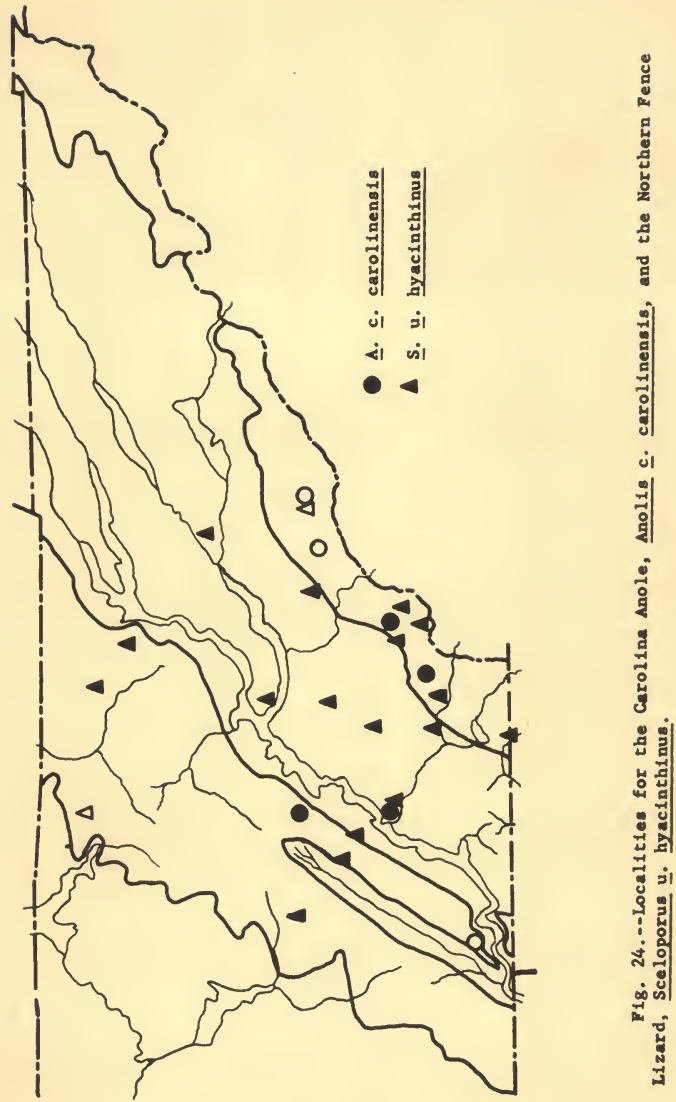
open oak-pine communty seems to be the more favorable thabitat. The highest elevation of known occurrence is 1,600 faet.

Cenus Sceloporus, Spiny Lizards. Forty・ntne specimens (21 femeles, 27 males, 1 of undaternined sex) of this genus have the following meristic data: snout-vent length, $25 \mathrm{~m}$. to $78 \mathrm{~m}$.; dorsal scala rows, 35 to 46, modal frequency 39 (27 per ceat of the specimens), 85 per cent of the series with 39 or mora; secles around aldbody, 38 to 48 , modal frequency 44 (8 specimans); femorel pores, modal frequency 14 (17 speclmens), 75 per cent of the apecimens with 15 or fewer. As regards these characters and coloration, the serias agrees with the daseription of the Morthern Fonce Lisard, Sceloporus undulatus hracinthinue (Green), as given by Satth (1946: 222-224).

This lisard is abundant in eastern Tennessea and occurs in esch of the physiographic provinces (Fig. 24). The most characteristic habitat is opan, second growth oelk-pine communities. It is very infrequant1y encountered In dense masic forest, and then uavelly near elearings of less mesie areas. The highest elavation of known occurrence of this 11saxd is 4,000 feat.

Fanily Anguidae

Genus Ophlasurus, Glass Snake. MeConkey (1954: 148) Includes eastern Tennessee In the range of the Bastern slender Glass Lizard, Ophrsaurus attenustus longlcaudue McConkey. Q. e. longlcoudus is differentiated frow the Western Sleader Glass Lleard, Ophisaurs a. ettenuatue Batrd, by the ratio between length of unregenerated tall and the anout-vent leagth. The two specimens of 0 . attenuatus avallable for 
examination do not have conplete talls, hence this character cannot be employed for these specimens. Several other differences exist between these specimens and the descriptions of the $\underline{0}$. attenuatus subspectes given by McConkey.

One specimen has only 16 rowe of scales around the bese of the tal1, which 18 two rowb less than reported for elther of the subspectes. This same apecimen has 15 dorsal scale rowe rether than the 14 or fewer reported for the species 0 . Attenuatus. Thls apeciman is from the Cumberland Plateau.

As regards coloration, each of these specimans differe from the type description of ㅇ․ 으. longlcaudus in several respects. The Cumberland Plateau specimen exhlbits the following differences: (1) the dorsal crossbands are from 1.5 to 2.0 sceles wlde, but are separated from each other by only 2.0 to 2.5 scales rather than by five scales, (2) laterally the crossbands extend to the upper half of seale rou four rather than to scale row three. The Unake Province specinen exhibits the following differences: (1) the dorsal body crosebands are only one scale wide rather than two and are separeted by only four scales, (2) the andlan helves of the two dorselmost scale rows have deflnite dark brown spote resulting in e distinct rather than vague viddorsel stripe, (3) the crossbands extend leterally to the upper half of scule row four, (4) the sides of the base of the tall poseess only four dark brown stripes separated by three white ones rather than five and four reapectively. Whether or not these color differences, as well ss the differences in soutellation mentioned above, are within the range of variation of ㅇ. a. Ionglcaudus 18 not known to me. 
These two specimens, and a specimen found dead on the road, are assigned to the subspecies 0. A. longlcaudus prinarily on the besis of geographle location (P1g. 25). All of then are from areas of second growth oak-pine-heath communties. The highest elevation of known occurrence 1s 2,200 feat.

Fanily Tetdae

Ganus Cnemidophorus, Racerunners. Three famales, 10 males, and 1 Individual of undetermined sex comprise the series of this genus avallable for study. The greatest sxout-vent length among these specimons 18 that of a fersale and $1881 \mathrm{~m}$. The tall is 1ncomplate. The lexgest snout-vent length of a male $1 \mathrm{a} 77 \mathrm{ma}$. The tall of this specimen is incomplete. These specimens do not differ from the description of the Six-1Ined Racerunner, Gremidophorus sexlineatus (Linnseux), as given by Burt (1931: 81-82) and by Sinith (1946: 412-413).

I have no record of this lizard from the Cumberland Plateau, but I have no doubt that it occurs there. It is abundant in the Valley Province and In the Unake Province up to elevations of about 2,000 feet (Fig. 25). Although 1t may be found in forested areas, it is not a deep-forest inhabitant. Rather, its distribution in the forests seems restricted to clearings, rock ledges, roadveys, and the 11ke. It $1 \mathrm{~s}$ not uncoumon in open oak or oak-pine commulties, as well as in fields.

\section{Fanily Sclnetias}

Genus Lygoeome. The Ground Skink, Lygosomen leterale (Say), is reprecented by a series of 17 fanales and 9 males. Snout-vent lengths 


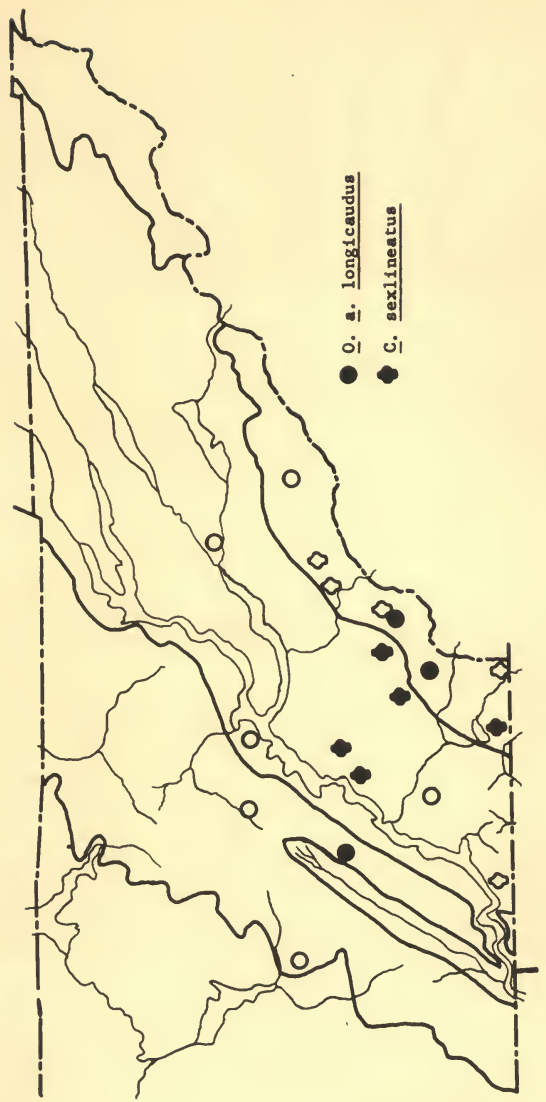

뭄

혛

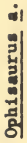

ज्ञ

क

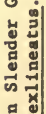

品

岁

ثै

กิ

की

की

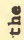


of females range from $26 \mathrm{~mm}$. to $47 \mathrm{~mm}$; those of the anles range from $24 \mathrm{~m}$. to $44 \mathrm{~mm}$. While these specimens agree with the description of th1s species as glven by Secth (1946: 337-338), none of them exh1bits the intense dark streaking on the throat and abdomen as seen in spec1mene from Loulsian (Johnoon, 1953: 14). The smallest Individuals exhiblt the three to four emall keels on the scales as do specimans of comparable size from Loula1ana. Comparison of the mean nusber of dorsel scales of the Tennessee material with that of Loulsiana material ouggests posstble geographle varlation of this charecter.

The mumber of doraal scales for the Tenneseee material are as follows: males, range 59 to 67, mean 62.7; fersales, range 66 to 75, moan 67.9. The mean value for these males ds four rows less than the mean for Loussiane males. The mean number of scales for Tennessee females 1s 3.2 less than the mean for Loulsians fomales.

Th1s Liard 1s widely distributed In eastern Tennessee (F1g. 26). It is most abundant in deciduous forest, although it is also encountered in open oak or oak-plne conmuntites. It is not found in flelds unless these are adjacent to woodland. The highest elevation of known occurrence is 2,500 feet.

Genus Euneces, Stripod Skinks. Zour spectes of this genus occur In eastern Tennessee. These are the Five-1Ined Skink, Fumeces fasclatus (Winnaeus), the Broad-haaded Sk1nk, Bumeces laticeps (Schne1dor), the Southeastern I1ve-11ne SkInk, Bumeces Inexpectatus Iaylor, and the Coal Skink, Bumaces anthreclnus (Baird). 


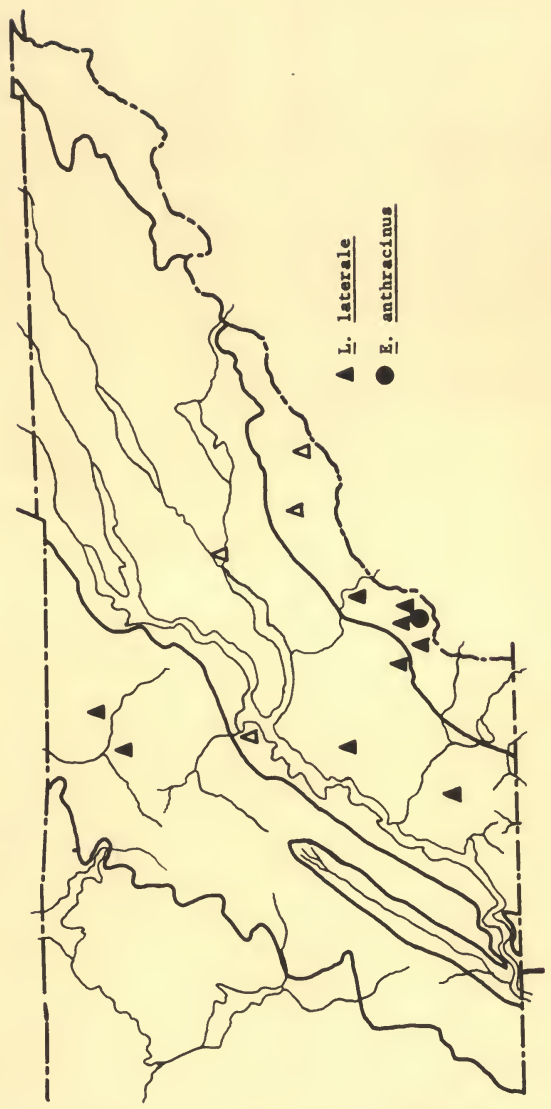

சै|

莒

\&

무

형

힘

है

동

s.

:

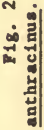


2. fasclatus 18 represented by a serles of 17 females, 9 asles, and 2 juventles of undeternined sex. The largest female has a snoutvent length of $72 \mathrm{~m}$. The largest male has snout-vent length of $73 \mathrm{~m}$. These 28 specimans ara designated as $\mathrm{z}$. fasclatus on the basis of the following comblnation of characters: (1) dorsolatend Light IInes on scala rows thrae and four at wdbody, (2) scales around atdbody ranging from 26 to 31, (3) two enlarged postlablel scales, (4) termination of the Iatercalary row of scales on the fourth toe at or on the second phelanx. Oaly 7 of the 28 apecimens do not possess all 4 of these characters, and none of these 7 possesses more than one charecter which is uaully assoclated whth E. 1aticeps. Variations encountered ara discussed under ㅍ. 1aticeps.

This skink is of wideapread distribution (Fig. 27). While predoninantly a woodland Inhabitant, it is not Infrequently encounterad in clearings in and around woode and home sites. As with the other three specles of Eumeces it 18 seldom oncountered in habitats as xerle es those In which Cnenidophorus and Sceloporus occur. The highest elevation of known occurrence for this 11zard is 3,700 feet.

E. Laticeps 18 represented by a serles of 5 fenalas and 3 males. Snout-vent lengths of the largact fensle and anle are, reapectively, $100 \mathrm{~mm}$. and $85 \mathrm{~mm}$. These 8 specimens are assigned to the species $\mathrm{I}$. laticeps on the basis of the following combination of characters: (1) dorsolateral 11ght IInes on scala zons four and flve or only row four, (2) scales axound midbody 31 to 32 , (3) one postlabial scale or two cmall ones, (4) termination of the Intercalary row of scales on the 

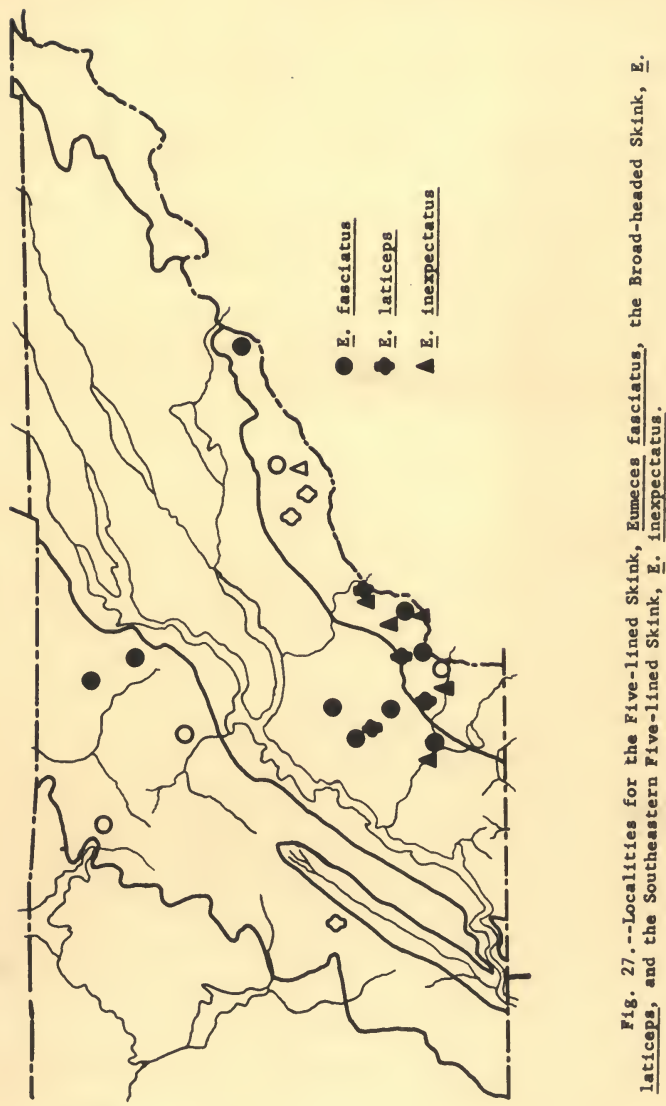
fourth toe at or on phalans three, (5) tertiery teuporal seale in contact with the last supralablal scale. Only two specimens possess charecter number 5. S1x of the 8 specimens possess all 5 of the characters. of the remaining 2 specimens, one has the dorsolateral light lines on scale rows three and four, the other has the Intercalary row of scales tervalating on phalans two.

Among the seven E. fasclatus wontloned above as exhibiting $\mathrm{E}$. latlcepe character, the varlations are as follows: three specimens have the Intercalary row of scales terafnating on phalanx three of both feet; one epecimen has this row of scales cerminating on phalanx three on tha left foot only; two epecinens have the dorsoleteral I1ght IInes on row four at milbody, one has then on rows four and five at wibody. Whether these variations in the specimens of $\mathrm{E}$. Easclatus and $\mathrm{E}$. 1aticeps are "nornal" for the two spectes is not known by me. Conant (1951: 210, 212) reports that Ohso specimens of $\mathrm{E}$. fasclatus do not have cowplate combinations of $\mathbf{E}$. Iaticeps characters, and that $\mathrm{E}$. laticeps specinens do not have more than one ‥ fasclatua character.

The criterion of enlarged or reduced postlabial scales is vary subjective as eaployed in tha 11tarature. In ordar to make it a more objective criterion, I a basing the relative sizes on the helght of postlablals/hotght of ear opening. The coabinsd height of the postlablal scales and the beight of the ear opening are measured with an ocular mferometer. The ratio between postlabial helght and ear opening helght from the two series of epecimeno are as followe: ‥ Easclatus, range 0.89 to 1.46 , mean $1.24 ;$ E. laticeps, range 0.47 to 1.10 , man $0 . x_{0}$ 
Only ore of the 28 specimens of ‥ fasclatus hes a ratio $(0.89)$ of lees than 1.00. Of the eight specimens of B. laticeps, afX have this ratio lese than 1.00 , one has a ratio equal to 1.00 , and one has a ratio of 1.10. Melther of these last two spectmens has any of the other criterla assigned to E. fasclatus. Of the $a 1 \times$ E. laticeps with ratios of less than 1.00, two have only one postlabial on each side and two (including the specinen with the ratio of 1.00 ) have the tertiary temporal In contact with posterfor supralabial. Th1s criterion, postlablal halght/ear opening helght, is of questionable diagnostic value, but it 1s highly suggestive and presents a poscible seans of deterning objectively whether or not the postlebials are enlarged. This ratio has been calculated for the apecimans of I. Inexpectatus and is reported in the discussion of that species.

The variation in numbers of scale rowe is es follows: $\mathrm{E}$. fasceatus, 26 (1 specimen), 28 (5 specimens), 29 (6 spectwons) 30 (11 spec1mens), 31 (3 specimens), 32 (2 specimens); $\mathrm{E}$. Leticepe, 30 (5 specimens), 31 (2 specimene), 32 (1 specimen).

E. Laticepe is restricted to woodland habitate, although it noed not be denen woods. King (1939: 510) Implles that this 1s a lisard of weric habitate. I, too, have encountered it in oak-pine forest, but always in the vicinity of water. The frequent occurrence of this lizard In strean valleys askes it a characteristic Inhabitant of floodphin communities. I have no record of the oceurronce of this l1sard on the curr berland Plateau (F18. 27). No doubt it w111 be found there, at least in the entrenched strean valleys of the edge of the plateau. The highaet elevation of known occurrence is 3,000 feet. 
E. inexpectetus is represented by a series of 8 females and 11 males. Snout-vent lengths of the largest fenale and male are, respecElvely, $72 \mathrm{~ms}$, and $73 \mathrm{~mm}$. These 19 specimens are allocated to this apecies on the besis of the following comblnation of characters: dersolateral 1ight lines on scale row four or rows four and five; (2) scales around midbody 29 to 31 , (3) termination of the interealary row of seales on the fourth toe of the foot at or on phelanx two. As regards the ratio between helght of postlablals and height of ear openIngs, 12 have this ratio less than 1.00, 6 have 1 equal to 1.00 , and 1 has a rat10 greater than 1.00 ; range 0.75 to 1.22 , mean 0.96 . Two specimens heve 29 scale rows around aldbody, 16 heve 30 rows, and 1 hes 31 rows. S1xteen gpecimens have the intercalary row of scales on the fourth toe terminating at or on the second phalanx, 3 spectmen have this row of scales terminating on the second phalanx of one foot, the third phelanx of the other foot. Nine specimen have the dorsolateral 11ght linec on scale row four, tea specinens have these IInes on row four and Elve.

In E. Inexpectatus the width of the median subcaudal scales is IIttle if ang greater than the length of these scales on umregenerated parts of the tall; the width of these scales is wuch wider than the length in both ․․ Easciatus and ‥ laticeps (Salth, 1946: 352). The results of ocular mferoneter measurements of these dinensions on $22 \mathrm{E}$. Eesclatus, 8 E. 1aticeps, and $13 \mathrm{~g}$. 1nexpectatus are as follows (reported ae ratios of length/wldth): E. Easclatus, range 0.31 to 0.53 , man $0.350 ;$ E. 1aticeps, range 0.31 to 0.51 , mean $0.436 ; \mathrm{E}$. Inespectatus, 
range 0.45 to 0.53 , mean 0.507 . These suggest that this charecter is of relative value rether than of ebsolute value. Further, I infer from all of the date presented above that these three specles of sumeces are in noed of eriticel systematic review.

By far the greater number of spectmens of $\underline{\text {. }}$. inexpectatus are from the Unake Provinee (Tig. 27). Here it is most frequently encountered in clearings, elther natural or artificlel, in the declduous forest habitats. The highest elevation of known occurrence 1s 4,000 feet.

E. enthrecinus 18 represented by two specimens, both Juvenlles. One is e male, the other presumably e female. Both are 31 mm. in snoutvent length. Bach has 26 seale rows around the midbody and $7 / 7$ upper1eblals. Bach of them is so darkened from preservation that color descriptions are questionable. It is deened best marely to designate these es B. anthractnue subspecies.

These two specimens cane from a grassy clearing in beech-heralock forest at en elevetion of 3,700 feet (F1g. 26). This collection site In the Unaka Province is in the area of intergradation between the Northern Cosl Skinik, Eumeces E. enthracimas (Beird), and the Southern Coal Sking, Eumeces a. Pluvialls (Cope), as shown by Salth and santh (1952: 681).

\section{Order Serpentes}

The snakes of eastern Tennessee consist of 2 fanilles, 17 genora, and a minimum of 22 species. In the following eccounts the numbers of ventrels and ventrals plus ceudals axe recorded eccording to the method of Schmidt end Davis (1941: 26) and Dowling (1951). The counts per Dowling 's mathod are enclosed in parentheses. 
Fandly Colubridae

Cenus Natr1x, Water Snakes. Two spacies of this genus are present In eastern Tenneesee. These are the Queen Snuke, Vatrix septemvittate (8xy), and the Common Water snake, Eatrix slpedon (hinnaeus).

I. septenvittats 10 represented by a serles of five female and four wales. Date obtalned fron these opecimans are as follows: feales, anout-vent length, $140 \mathrm{~mm}$. to $524 \mathrm{~mm}$; tall 1ength, $52 \mathrm{~mm}$, to $161 \mathrm{~mm}$; ventrals, range 132 (131) to 141 (138), mean 137.6 (135.8); caudale, range, 72 to 78 , masn 75 ; meles, snout-vent length, $316 \mathrm{~mm}$. to $436 \mathrm{ma}$. ; tall length, $149 \mathrm{~mm}$. to $175 \mathrm{~mm}$ : veatrals, range 135 (135) to 140 (138), man $137.5(136.3)$; ceudals, range, 79 to 89 , wan 84. Date from both seves consldered together are as follows: upper labials, 7/7 (8 apeclmens), lower lablals, $10 / 10$ ( 7 specimens), $8 / 8$ and $11 / 10$ ( 1 spectmen); pre- and postoculars, $2 / 2$ (9 epectmens); scale rows, $19-17$ ( 9 opec1mens).

Scutellation date from these opecinens differ from Ohlo epeclmens (Conant, 1939: 77) and from Florsda spectanens (Carr and Goln, 1955: 288) In the following particulare: the pintmum, maximum, and mean numbers of ventral scutes of these femules are, respectively, 6, 12, and 8.1 vcales less than these values for Ohlo spectmans, and 3,7 , and 4.4 less than these values for Florida femeles; the minimum, aximu, and wean mubers of caudals of these femnles ara, respectively, 8, 6, and 7 more than these values for Ohio females, and 11, 6, and 7 more than these values for Florida fenales; the minimum, maxtmum, and moan mubers of ventrals of these alas are, raspetively, 3, 14, and 6.9 lese than 
these values for Florida anles; the ninimum, maximum, and meen numbere of caudels of these males are, respectivaly, 7, 10, and 8.6 more than these values for Ohlo males, and 15, 5, and 6 more then for Floride males. Whether these differences are reel by only apparent es e result of the anall sample size is not known at present.

The color of five of the specimons ( 3 fenales, 2 males) agrees essentielly with the descriptions as given by Conant and by Carx and Goln. The renaining four speciwens, ( 3 females, 1 male) have venters quite different from the ebove five specimens. Only the chin, gular reg1on, and e weximun of 14 anteriormost ventrels can be considered es belng yellow, where not occupled by paramedian serles of gray or brown spots which unite In the gular region Into single median 11ne. Posterlorly from ventral 14, these sertes of spots become 11ghter on three spectmens and obsolate on the fourth specimen. The ground color between end on elther side of the paramedian serles of spots is whitish enteriorly, beconing derk slete gray, sometimes mottled with brow, posteriorly. On each of these four specimens the extreme ldtrel edges of the ventrel scutes and the botton half of the firat scele row are clouded with brown and contrest distinctly with the color of the dorsum and the venter. The leterel light ettipe is obsolete on the anterlor half of the body of each of these four specimens.

The Queen Snake is probably wore abundant than collected spectmens indicate (F18. 28). It is encountered most frequently elong the minor streams of the Velley, but malso be found in the cooler, clearer, end more owlft streass of the mounteins. It does not, epparantly, 


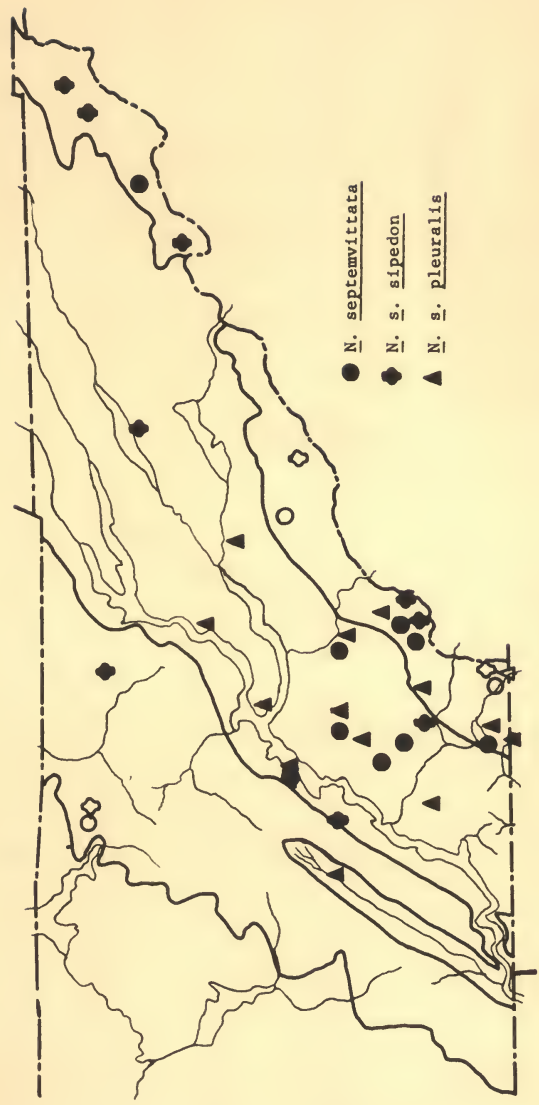

cँ 出 壱

림

岂

$\times$

네

究目

Z1

के

范

कू

독

है. :

ב \&

山ै

म웜

फ

兵?

건 딩

$\rightarrow$ 밀

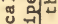

品

: का

$\infty$.

次宊

$\infty$.

is

웡

귁

zi का 
Inhabit ponds or temporary aquatic situations. The highest elevation at whleh 1t 1s known to occur 181,700 faet.

Fifty-three specimens (31 females, 22 males) of $\underline{\underline{H}}$. sfpedon are avallable for study. Casusl observation of these specimens suggeste that some exhiblt charactaristics of the Mortharn Water Snake, Vatrix $\mathrm{g}$. slpedon (Linnaeus), and that others exhlblt charactoriatice of the Midland Water Snake, Matrix s. Pleuralis (Cope). Published data Indicate that only the former 1s prasent In eastern Tennessee (Clay, 1938; Schmidt and Davis, 1941: 221; Wright and Wright, 1957: 512). However, Ash (1945: 264) raports that some of the specimens which he exanined are very much like ㅍ. s. pleuralls.

Analysis of these specimens 18 besed upon some of the eriterla eaployed by Clay (1938) to distinguish the two subspectes. These criterla are as follows: relative wldths of lateral bars and lataral interepaces--bars equal to or greater in width than Interspaces In ㅆ. ‥ slpedon, narrover than Interepaces in ㄴ. s. pleuralls; total number of dorsal body crossbands and blotches counting from the nape to a polnt above the closcal apertura--31 or more in 1 . . . slpedon, 30 or fewer In I. I. Plourelis; general coloration--grayloh to black1sh in I. S. sipedon, brownish to reddish in I. S. Pleuralis. Clay also employed the number of anterlor crossbends and the number of ventral scutes in separating these two subspecies. I have found these two charactere of $11 t$ te $^{2}$ value. Conant (In 11te.) also Informs ne that he finds these churacters of litele value in saparating the two forms.

The total humber of dorsal crossbands and blotches renges from 26 to 39 , mean 30.8. Thls mean velua is approximately the upper 11mit 


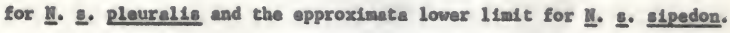
Thus the everage for the entire serles is intermediete between the two subspecies. These data are besed on 50 specimone; the other 3 heve patterns too obsolate for sceurate counte. Of 24 specimens with 30 or fewor dorsal blotehes, only 3 epecimens are fros elevations in excess of 1,000 feat. These are from 1,600 feat and 1,800 fest in the Unake ProvInce. Of thase 24, only 5 ara from localfties north of approximately latitude $35^{\circ} 30^{\circ} \mathrm{x}$. , end all $\mathrm{S}$ are from elevations below 1,000 faet. Mrenty-seven specimens have total counts of 31 or more dorsel blotches. Bleven of these are from localities south of letitude $35030^{\prime} \mathrm{u}$. Four of these 11 are from locallties et elevetions of 1,000 feet or lass; 7 from elevations in excess of 1,000 feet. The remaining 16 specimen of this group are from localities north of letitude $35^{\circ} 30^{\circ} \mathrm{W}$. In sumary, 21 (88 per cent) of the epecimens with 30 or fever dorsel spots are from collection sites south of latitude $35^{\circ} 30^{\circ} \mathrm{m}$. and/or below 1,000 feet in elevetion; 23 (85 per cent) of the specimens with 31 or mora dorsal blotches are fron locelities north of latitude $35^{\circ} 30^{\prime} \mathrm{w}$. and/or abova 1,000 feet in elavation. The known aaximum elevetion ettalned by $\underline{x}$. 1pedon In eastern Tennessea is 4,800 feet.

Laterel bar and lateral interspece vidths are reported in terme of scale lengths. These are deteralned es follows: the number of scales in each bar and each interspace is counted to the nearest half ocele on three consecutive bars and Interapaces beginning et a point below the level of the sixth dorsal band or blotch; the six counts, three from each sida, for the bars and interspaces are overagad. The counting is done on the third scale row. 
The widthe of the lateral bars ranges from 1.1 to 2.7 , mean 1.8 , scales wide. The lateral interspaces range from 1.9 to 4.3 , mean 2.8, scales wide. Only three specimens possess lateral bars as wide as the lateral interopaces. One of these 18 from an elevation of 900 feet at latitude $35^{\circ} 30^{\prime} \mathrm{M}$. . The other two are from locellties ranging from 1,200 feet at latitude $35^{\circ} 45^{\prime} \mathrm{x}$. to 1,400 feet at latitude $35^{\circ}$ 30 ' M. Thus, except for one spetiman, those specimens exhlbiting the ע. s. Slpedon charneter of lateral bars equal to or wider than lateral Interspaces are restricted to latitudes north of $35^{\circ} 30^{\prime} \mathrm{w}$, or, if from areas south of this latitude, then they are restricted to elevations in escess of 1,200 feet. This situation parallels that reported above for the ditribution of speclans with 31 or more dorsal blotches. Color is a most difficult character to evaluate objectively in ‥ alpedon. Generally, I. S. pleuralls is described as belng redder than ‥ ․ sipedon. Conant (1939: 81-82) describes ㅌ. ‥ slpedon from Ohio as being extremely variable: blotches range from gray to brown to reddish; ground color ranges frow whitish to gray or brovn. Similarly, these specimens range from dark greenish gray to brown and red. In some Instances, the dorsal blotches are rendered nearly obsolete by darkness of the apeciman. Without exception, these specimens are from the higher latitudes or elevations.

The ground color of the venter of these specimens ranges from white to greenish white to yellow or pinkish. Occasional specimens exhibit a longitudinal midventral yellowith or pinklsh area. The markings on the venter may be crescents and/or flecks and marbling, varylng in 
color from black to red. The crescents may occur in 1rregularly allgned longltudinal rows or as two wall-defined rows which converge posterlorly. On many Individuals the crescents may becone obscured posterlorly by an Increase in the amount of flecking and/or marbling, whlch may or may not be of the same color as the crescents. All locallthes considered, the mafority of the specimens exhiblt pairing of the crescent-shaped marks, a. ‥ ‥ pleurelle character.

There 18 no definite correlation between color and collection s1te. However, more brown or reddlsh specimene and more opecinens with paired reddish veatral crescents are from the Valley Province or from low elevations in the mountalne. Conversely, more of the 11 ght to dark gray epecimens are from the higher elevations in the mountains or from farther north in the Valley Province.

Fron the above date it 18 evident that the $\underline{\text { I. }}$ sipedon population of eastern Tennessee ts at least an Intergradient one between 프. 으. slpedon and $\mathbb{N}$. 2. Pleuralis. The lafluence of the formar is greatest In Valley areas north of latitude $35^{\circ} 30^{\prime} \mathrm{w}$. , which is the approximate latitude of the Little Teanassee River, in the Cumberland Mountalns, and at elevations in excess of 1,200 feet in the wountalns south of the Little Tennessee River. The Influence of ‥ S. Plouralls is most apperent In Valley areas south of the Little Tennessee River, in the Cumberland Plateau south of the Cumberland Hountains, and in the Unake Province at elevations below 1,200 feet. These distributions are shown in Figure 28.

The Common Water Snake ranges throughout eastern Tennessee and aay be encountered in nearly every type of aquatic sltuation. It 18 
most characteristic of rivers and streans, but is not infrequantly encountered in ponds and pools.

Game Storeris, Brown Snakee. This genus is represented in eastera Tannessee by two species: the Brown Snake, Storerla dekay 1 (Holbrook); the Red-bell1ed Snake, Storer1a occlpitomaculata (Storer).

Four female and three male spectmans of $\underline{\mathrm{s}}$. dekay 1 are avallable. Data from the vexes consldered separately are as follows: femeles-o snout-vent length, $188 \mathrm{~mm}$. to $325 \mathrm{~mm}$; tall langth, $49 \mathrm{man}$. to $68 \mathrm{~mm}$; ventrals, range, 123 (121) to 129 (128), mean 126 (125); caudals, ranga, 42 to 44, mean 42.8; ventrals plus caudals, range, 167 (165) to 171 (170), mean $168.8(167.8)$; males-osnout-vent length, $170 \mathrm{~mm}$. to 225 me.; tail length, $39 \mathrm{man}$. to $76 \mathrm{~mm}$; ventrals, range 122 (120) to 124 (122), mean 123 (120.7); eaudale, range 52 to 56, mean 54; vantrals plus caudale, range, 175 (174) to 178 (176), mean 177 (174.7). Data from the sexes considerad together, and In part employing the methods of Conant (1951: 238-239), are as follows: scale rows, 17 (6 specimens), 17-16 (1 spec1men); upper labials, $7 / 7$ (all spacimens); 1over lablals, 7/7 (6 specimens), $8 / 7$ ( 1 spacimen); pre- and postoculars, 1/1 (al1 spec1mens) and $2 / 2$ (all specimens); temporals, $1+1 / 1+1$ (2 spectnens), $1+2 / 1+1$ (2 spectmans), $1+2 / 1+2$ (3 spectmens); number of dorsal crosebands, 0 , $7+, 8+$, and 13 (1 specimen each), and 18, 24+, and 33+ (1 spacimen each). Considaring singla specimens, two possess 175 or fever ventrale plus caudals and 10 or fever crossbands charecteristic of the Northern Brown Snake, Storer 18 d. dekay 2 (Holbrook). One spacimen possessed more than 175 ventrals plus caudals and wore than 10 crossbands characteristic 
of the Mdland Brom Snake, storerla d. wrightorum (Trapido). One specimen possesees more than 175 ventrals plus caudals and fover then 10 crossbends. The remalning three specimens possess 175 or fewer ventrals plus caudals and more than 10 crossbands. Thus, 72 per ceat of the specimens are intermediate between S. d. dekayl and S. I. wrightorun. Adaittediy these axe scant data upon which to basa concluslons ragarding the $\mathrm{S}$. dekay 1 populetion of eastern Iennessee. But I Infer from these data that the $\underline{s}$. delayyd population of this area 18 Intermedlate between 8. d. dekay 1 and S. d. wrightorum.

The Brown snake appears to be equally comon under edificartan and forest conditions. Its greater frequeney in grassy clearings in forested reglons suggests that fts occurrance in forested areas is abatted by sylvicultural and agricultural activity. The highest elavation from whlch this snake is known in eastern Tennesece is 4,000 feat Fig. 29). It is Interesting to note that the specimen from this elevation Is the one possassing the high ventral plus caudal count and the high number of crossbands characteristic of s. ․ yrightorum. Of the two spectmens possessing the low ventral plus caudal count and the fower thien 10 erossbands charactaristic of S. I. dekay, one 18 from 1,000 feet in the Valley Province and one is from 1,500 faet on the Cumberland Pleteau.

Two opecimone, both malas, of the Rod-ballied Snake are avallabla. Thase are $99 \mathrm{~mm}$. and $145 \mathrm{~mm}$. In snout-vent length and $32 \mathrm{~mm}$. and $45 \mathrm{~mm}$. In tall length. Other data are as follows: ventrels, 111 (109) and 122 (120); caudale, 46 and 48; dorsel scele rows, 15 eech; upper 

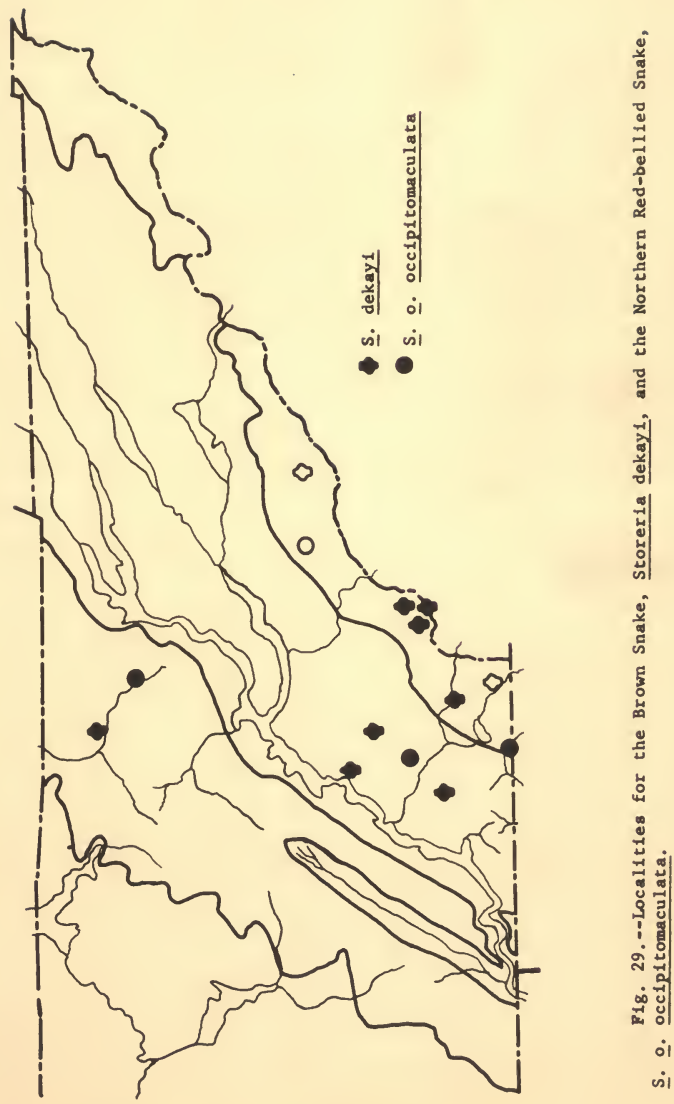
lablals, 6/6; lower leblals, 7/7; pre- and postoculars, 2+2/2+2; temporals, $1+2 / 1+2$ and $1+1+2 / 1+1+2$. Bach speciman has three occipital spots. The specimans are too darkened from preservation to discern longitudinal striping on the dorsum.

The ventral and caudal counte are lower than those given by Conant (1939: 92) for Ohio apecimene of the Morthera Red-bellied Snake, Storerie o. occipitomaculate (Storer). The number of ventrals of one of the males and the mumber of caudals of both are within the ranges of these counts as given for the Florida Red-bellied snake, storeria $\mathrm{O}$. obscure Irap1do, by Carr and Coln (1955: 291). Because there are but two specimens, no conelusions are reached as to the exact aystematic status of the eastern population of the s. ocelpiltomaculate.

Available Information Indicates that this snake is restricted to deciduous forest areas. The distribution of the two specimens suggests that th1s snake may oceur over most of eastern Tennessee where cond1t1ons are sultable (F18. 29). The highest elevation of occurrence of this snake 1s 4,950 feet (King, 1939: 576). Highton (personal communication) Informs we that he has encountered this snake at elevations in excess of 5,000 feet.

Gemus Thamnophle, Garter Snakes. Two spec1es of this genus are reported as occurring in eastern Tennessec. These are the Common Garter Snake, Thennoph1s girtelis (Linnaeus), , and the Ribbon Snake, Themnoph1s saur1tus (Linnaeus). Duthven (1908: 114), although 1ncluding cestern Tennessee within the range of I. seurltus, does not give any locality records in this or lanediately adjecent areas. Thoads (1895), 
KIng (1939), and Ash (1945) report no specimens of this snake. I have not encountered any during the course of this study.

Twenty-two feasile and 20 ale specimens of I. Birtalls are Identified as the Bastern Garter Snake, Thernoph1s s. 91rtalls (Linnaeus). The females have snout-vent lengths ranging from $174 \mathrm{am}$. to $691 \mathrm{ma}$. and tail lengths from $49 \mathrm{~m}$. to $192 \mathrm{~mm}$. The males have snoutvent lengthe ranglng from $161 \mathrm{~mm}$. to $480 \mathrm{~mm}$, and tall lengthe from 50 ma. to $149 \mathrm{~mm}$. As regards scutellation, these specimens are not different from the data reported for th1s subspecies by luthven (1908: 176). Iwo diatinet color pheses nay be recognised.

These two color phases are apparently correlated with elevation. The mafority of the specimens from elevations of 3,000 and more feet are a dull brow ground color with pale yellow atripes. Specimens from lower elevations are generally of the "typical" dark green ground color with bright yellow stripes. (These color differences become less distinct in preserved material.) Iughton (personal coumunication) has remarked about this high-elevation brown form. Ilo recalls encounaters wtth them on the sumatis of mountains during hls work on plethodon. King (1939: 576) reports melanistic Individuals from elevations in excess of 3,000 faet in the Great Smoky Mountains Mational Park. I have not encountered malanistic individuals at equally high elevations in the mountalns to the north or the south of the Great Smolk1es.

King reports that the average and the maximum numbers of ventrals dacrease slightiy with a decrease in altitude, but he quastions the significance of this trend. Data from my specimens indicate a reverse 
trend, the more so when the sexes are considered eeparately. Presumably Ring utilized combined data from both aexes. Further, nct only do the data suggest a decrease in the average and saximum numbers of ventrals with an Increase in elevation, but there is a parallal decrease in the maximum and average numbers of caudals and ratios between tall length and total length.

The specimens are grouped for analysis according to sex and to levetion of the collecting ste. The specimens are divided Into low elavation series, 2,000 feet or lesa, end high elevation series, 3,000 feet or more. There are no specimens from elevations between 2,000 and 3,000 feet. Further, this rather arbitrary division al ao effectively segregates the green and brown phases. Data from the females are a follow:

\begin{tabular}{|c|c|c|}
\hline & $\frac{\text { Low-elevation }}{\text { Sertes }}$ & $\frac{\text { Hish-elevation }}{\text { Serles }}$ \\
\hline \multicolumn{3}{|l|}{ Ventrals } \\
\hline $\begin{array}{l}\text { renge } \\
\text { meas } \\
\text { mumber }\end{array}$ & $\begin{array}{c}140(138) \text { to } 153(151) \\
146.9(144.8) \\
9\end{array}$ & $\begin{array}{c}143(141) \text { to } 147(144) \\
145.4(142.6) \\
5\end{array}$ \\
\hline \multicolumn{3}{|l|}{ Caudals } \\
\hline $\begin{array}{l}\text { range } \\
\text { mean } \\
\text { mumber }\end{array}$ & $\begin{array}{l}66 \text { to } 73 \\
70.2 \\
5\end{array}$ & $\begin{array}{c}62 \text { to } 67 \\
64.5 \\
2\end{array}$ \\
\hline \multicolumn{3}{|c|}{$\begin{array}{l}\text { Tall length/ } \\
\text { total length }\end{array}$} \\
\hline $\begin{array}{l}\text { range } \\
\text { mean } \\
\text { number }\end{array}$ & $\begin{array}{c}0.208 \text { to } 0.237 \\
0.225 \\
5\end{array}$ & $\begin{array}{c}0.212 \text { to } 0.218 \\
0.215 \\
2\end{array}$ \\
\hline
\end{tabular}


These data from the male opecimane are as follows:

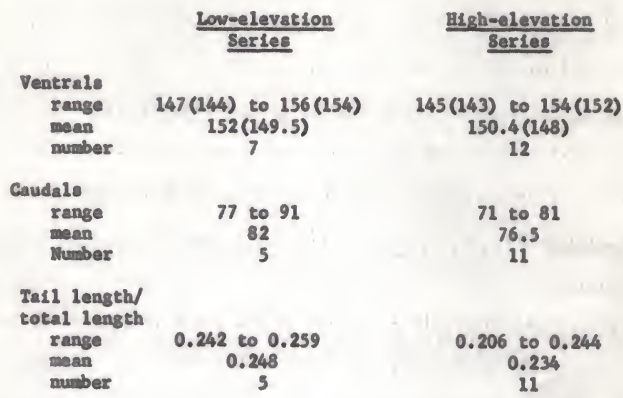

The inference from these date is that the above characters exhibit a vertical gradlent. Because of the andl number of specimens avallable, otatistical anslyeis was not performed. Whether or not the gredlent, If It really exists, io genetically or environmentally controlled remains to be discovered.

The Comnon Garter Snake is wldespread throughout eastern Tonnessee. It 10 apparently more abondant in declduous forest than in agricultural areas, and more abundent in the mountalns than in the valley or on the Cumberland Plateau (Fig. 30). In the mountalns 1t is parteularly characteristic of the ecotone between forest and clearling. Thls snake nay be encountered at elerations above 5,000 feet. The garter snake, the red-bellied snake, and the rattlesnake are probably the most high-ranging of eastern Teanessee serpents. 


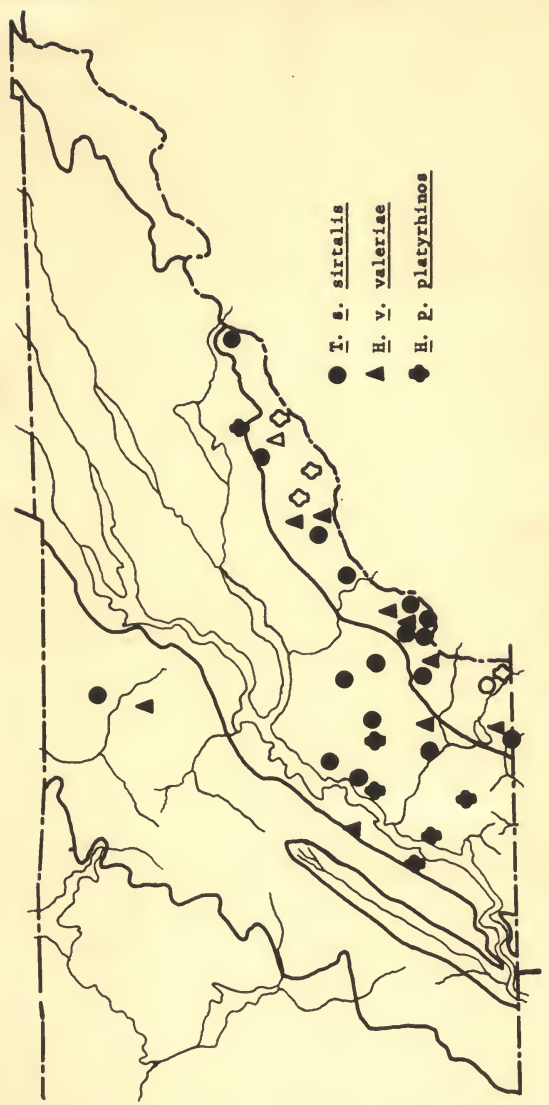

봄

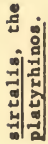

-i

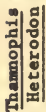

है है

농

点

논

노ํ

击

i >1

용 예

$\infty_{-1}^{\infty} \frac{1}{2}$

政

है 
Genus Haldea, Earth Snskes. Fourteen specimans of the Eastern Barth Snake, Bnldea v. valerlae (Baird and Girard), are avallable as a result of this study. All of these specimens are on loan to Mis Loulse 211118, Wosleyan Collage, Macon, Georgla, who is engaged in atudy of the semus. Mss $21111 \mathrm{~g} k 1$ ndly furnished we Information regarding these specians, and I quote, In part, froa her letter of August 19, 1957:

All of the spectmens of Baldes which you sent on loan were good Haldea velorlee valorles. The only Iennessee I. v. elegans known to wa are from the western portion of the state. Blegens has elso been reported fron Davidson Co. (SIncla1r 1951, Herpatologice VII, P. 145.)

There is no discernible eltitudinal or physlographic varietion Indleated by this nateriel, nor any significant verlation from the typlcal form. There is definite infraspec1fic geographical varietion in all forms of llaldea, which can only be defined in terms of frequency distribution of certain characters.

Th1s snake is not often encountered, but 1s distributed from the Unake to the Gumberland Pleteau provinces (F1g. 30). All of the epec1mens are from opan, grassy or "old fleld" hituations near woodland. The known mextium elevation of occurrence for 므. ‥ valeriae is 2,500 feet. Cenus Blaterodon, Hognose snakes. Four females and three males of the Eastern Hognose Snake, Heterodon R. elatyrhinos (Intrielle), are ovellable. The feanales range in anout-vent length frot $235 \mathrm{~mm}$. to 695 m. In tall length from $40 \mathrm{~mm}$. to $131 \mathrm{~m}$. The males range in snoutvent length from $435 \mathrm{~m}$. to $552 \mathrm{~mm}$., In tall length from $100 \mathrm{~mm}$, to 145 man. Scale rows at midbody are 23 (3 spectmens) and 24 ( 4 specimens). The terminal number of scale row 1 s 17 (2 specimans) and 19 (5 specimans). Other data are as follows: fewales-odoral blotehes, range, 20 
to 25 , wean 24.3 ; tall blotches, range, 7 to 9 , mean 8.3 ; 11 ght body bands, range, 21 to 25, mean 23.5; ventral scutas, range, 139 (137) to 147 (145), mean 142.7 (140.7); caudal scutes, range, 44 to 45, mean 44.7; males-odorsal body blotches, range, 17 to 22, mean 19.3; ta11 blotches, range, 9 to 10.5, wean 9.8; 11ght body bands, range, 18 to 22, mean 20; ventral scutes, range, 129 (127) to 135 (134), mean 131 (129.3); caudal scutes, range, 50 to 58 , mean 54. In color these: apec1mens are baslcally a reddish ground wth black or dark brown dorsal blotches. The ventar is yellowish graen laterally, tonding toward greenlah black medially. The undersurface of the tall 1 d distinctly IIghter then the venter. In these respecte, the specimans are in essent1al agraement with the deseription of B. R. platyrhinos as given In Carr and Coln (1955: 269-270) and In Wright and Wright (1957: 306-308).

The few specimeno collected are not considered as representing a mager populat1on. Rather, thelr nost characteristic habitat of old f1elds, cultivated aren, atc., were not extensively collacted. Host of the specimens encountered dead on the road are adjecent to such areas. The hognose snake is not a chatacteristic inhabitant of woodland, although occasional opecinen wy be encountered in second-growth oak and oak-pine comunities. It 18 most prevalent in the Valley (F18. 30). The known maximum elevation of occurrence 18 2,500 feet.

Genus Dledoph1s, Ringneck Snakes. IIghty-four specimens (45 females, 39 ales) of Bastern Ringneck Snake, Dledophle punctatus (hinnaaus), are the basis of the following remarks. These specimone are examined on the basas of criteria employed by Blanchard (1942) and Conant (1946). 
On the basis of scutellation these specimens are closest to the Northern Ringneck Snake, Diedophle R. edvardsi (Morrem). All of the spectmens have 15 dorsal scale rows. The frequency of occurrence of varlous numbers of upper lablals is as follows: 7/6 (1 spectmen); $7 / 7$ (8 apecimens); $7 / 8$ or $8 / 7$ (11 apectmens); $8 / 8$ (44 specimens). The remalning apecimens are untabuleted for this character. Other date from these apeclmens are as follows: fomales-oventrals, range, 153 (151) to 178 (177), mean 162.8 (161.6); caudal scutes, range, 42 to 63, mean 52.8; ventrals plus caudals, range, 198 (197) to 236 (235), man 215.4 (214.3); width of neck ring in terms of scale lengths, range, 1 to 2 , mean 1.39; ratio between tall length and total length, range, 0.184 to 0.285 , mean 0.206 ; males--ventrals, range, 140 (139) to 166 (166), mean 153.9 (152.7); caudal scutes, range, 33 to 66, mean 54.2; ventrels plus caudals, range, 199 (197) to 224 (222), wean 213.1 (211.8); width of neck ring in terms of scele lengths, range, 1 to 2, meen 1.5; ratio between tall langth and total length, range, 0.176 to 0.250 , mean 0.226 . There is no apparent geographle variation in these characters. Females range in snout-vent length fron $113 \mathrm{~m}$. to $396 \mathrm{~mm}$.; in tall length from $27 \mathrm{~m}$. to $100 \mathrm{~mm}$. Males range in snout-vent length from $107 \mathrm{~m}$. to $400 \mathrm{~mm}$, In tall length from $32 \mathrm{~mm}$. to $102 \mathrm{~mm}$. In both feanles and males, the longest snout-vent length is not correlated with the longest tall length. But, the sallest snout-vent length does correspond to the sallest tail length.

Three aspects of coloration are employed to dietingulsh D. R. edwarde1 froa the Southern RIngneck Snake, Diadophis R. punctatus (Linneous). Only 12 specimens, 5 ferales and 7 males, have all three of the 
characteristics of D. R. edvards: : uninterrupted neck ring, unspotted chln, and Immeculate belly. The remalning 74 specimene possess one or more of these characters plus charactars assigned to D. R. punctatus: Interruptad neck rIng, spotted chln and gular reglon, apotted belly (these spots usuelly in an uninterrupted median series and larger than the spots which are somatimes present in D. R. edvards1). In eaploying these cfiterie to evaluate the specimons, I followed the plan used by Conant (1946). Additionally, my standards ore based upon a series of D. R. punctatus from Alken County, South Garolina.

Twenty-six specimens possess an incoupletely or completely interrupted neck ring. Nwenty-five of these are from the Unake Province, one 1s from the Cumberland Plateau. Blanchard (1942: 119) reports an Inc1dence of 15 out of 900 D. R. edvarder with a broken neck rtng, and 43 out of 91 D. R. punctatus with this condition. Conent $(1946: 477)$ reports an Incidence of only one specimen out of 27 D. R. edvards1 from the Pocono Mountalns, Pennsylvania, with an Interrupted neck ring. The specimens are most 11ke D. p. punctatus as regards Incldence of Interrupted neck ring.

Thirty-seven specimens posseas a spotted chln, lablals, and/or gular region. Of these, 32 are fron the mountain sector, 1 is froe the Valley Province, and 4 are from the Cumberland Plateau. Sixty-two speclmens possess a venter which is heavily spotted with a median series of large, half-moon spots or are lacompletely spotted on the venter with a median serles of irregularly shaped spots. Fifty-two of these are from the Unaka Province, 3 are from the Valley Brovince, and 7 are from the 
Cumberland Plateau. Of 21 specimens possessing an imaculete venter, 12 are from the Unaka Province, 1 1s from the Velley, and 8 axe from the Cumberland Plateau. Three specimens from the Unake Province have belly patterns suggeative of that of the Mississipp1 Ringneck Snake, DLedophis R. atictogenys (Cope). The apots on the venter of one specimen are arranged in a paired median seriee and at if formed from the coalescence of paired paramedian apots in the other two opecimone. Additionally, these latter two opecimens have opots leterel to the median series. From the above deta on coloration, I conclude that Intergradat1on occure between D. R. edvardsL and D. R. punctatus in eastern Tannessee. The mountain populetion is wost intermediete between these two subapecies. The populations of the Valley and the Cumberland Plateau are more nearly like the description of typlcel D. R. edverdel. It may appear anomalous that e cosstel plafn snake may lavade a physlographle mountainous reglon more readily than adjecent valley lands. I belleve this 18 the reason conant (1n 11tt.) disagrees with my interpretation of the D. punctatus population in eastern Tennesses. For reasons to be presented later in the paper, I belleve that it may be easler for mosic cosetal plein reptiles to invade the mountalnous region of southeastern United States then the drier Valley and Cumberland Plateau districts. The ringneck snake 1s wideepreed in cestern Tennessee (Fig. 31). It is a snake characteristic of forest land, especially mesic deciduous forest. In the Valley and on the plateau it secens to be confined to or near strean velleys or other molst areas. Individuals appearing to be typicel D. R. edvardsi may be found in more xeric situations than the 


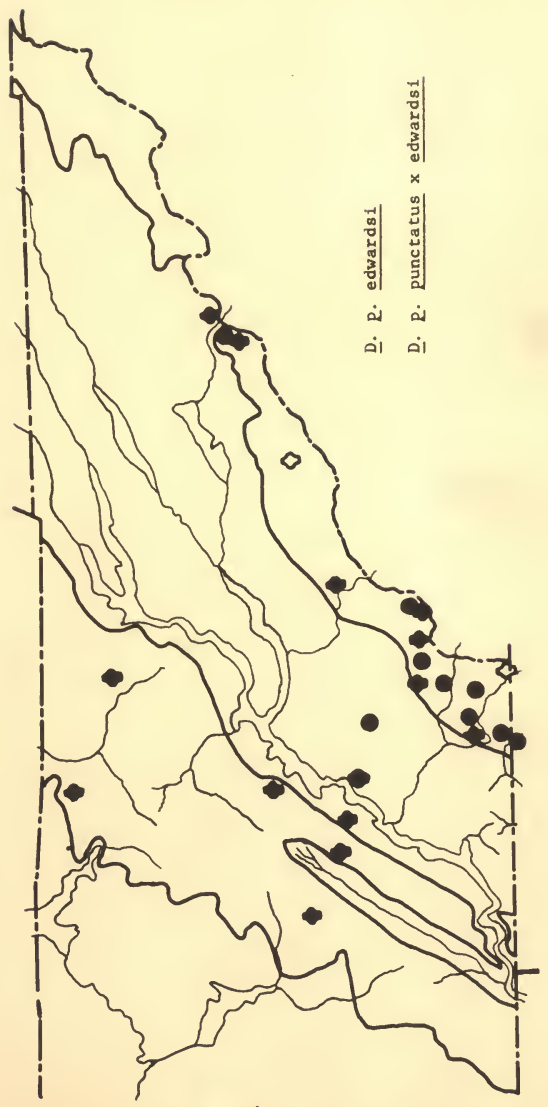

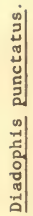

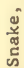

ư

논 
Individuels appearing to be D. R. punctatue or D. R. edvardal $\times$ D. R. punctatus intergradas. All three kinds of Individuals any be encountered together in the mounteins and at the same elevations. The known maximun elevation of occurrence for the ringneck sneke is over 5,000 feet In the Unaka Province.

Gonus Carphophls, Worm Snakes. Porty-eight femeles and 60 anales of the Worm Snake, Carphophls amoenus (Say), are the basis for the following reaarks. Females range in snout-vent length from 89 man. to 216 $\mathrm{mm}$. In tall length from $13 \mathrm{~mm}$. to $37 \mathrm{~m}$. Hales renge in snout-vent length from $85 \mathrm{~m}$. to $204 \mathrm{~mm}$., in teil length from $17 \mathrm{~m}$. to $50 \mathrm{~mm}$. Twenty females and 27 males, selected to represent the Cumberland Pleteau, the Velley, and Unaka provinces, are the source of the date recorded below.

Iach of these specimens has 13 scale rows, 5 upper lablels on eech side and 6 lower lablels on eech side. There is slight variation In numbers of temporels as follows: 45 specinans have one temporel on eech side; one specimen has one temporel on one side and two on the other; one speciman has the temporal fused to the last upper leblal on eech s1de. Among the 20 females, the mumber of ventrel scutes ranges from 119 (116) to 128 (126), mean 124.7 (123). For these femules, the number of caudals ranges from 25 to 36 , meen 26.9 . For 27 males, the number of vantrals ranges from 112 (110) to 122 (120), wean 117.2 (114.6), and the number of caudals renges from 32 to 40 , waen 36 . The ainimal number of ventrals is lower than the minimum reported by Blenchard (1925) for elther the Eastern Worm Snake, Carphoph1s 
a. emoenus (Say), or for the Midvest Worm Snake, Carphophls a. helenae (Kenalcott). The mans are less than those gtven for elther c. a. amoenus (mean 131) or C. a. helense (mean 128).

of these 47 specimens, 5 females and 6 males have fused Internasal and prefrontal scutes on each side of the head. One female and 2 males have these scales fused on only one side. Of the total of 108 epecimens, 18 have the Internasis and prefrontals fused on each side and 5 have then fused on one side only. These data are interpreted as Indicating Intergredation in eastern Tennessee between G. a. amoenus and c. s. helenee. Of all opecimens showing fusion of Internesal and prefrontal scutes, 12 are from the Unaka Frovince, 8 are from the Cunberland Plateau, and 3 are from the Valley Province. On a percentage bas1s, 14.4 per cent of the Unake specimens, 40 per cent of the Cumberland specimens, and 77.7 per cent of the Valley specimens exhiblt fusion of these scutes. Thus the zone intergradation mey be opeculated as extending southward on the Cumberland Plateau and in the Valley from Middlesboro, Kentucky, (Smlth, 1948) to the southern border of Tennessee.

The worn snake is characteristic of the deciduous Forest, but it may be encountered in oak-pine communities if the so11 is not too tight. It is most abundant in loose loan or sandy-loam so11s and least abundent In the heavier clay solls. This snake is widespread throughout eastern Tennessee and is know to occur at elevations of 4,300 feet (F1g. 32). Genus Coluber, Racers. Fourteen female and 14 male specimens of the Racer, Coluber constrfetor (part) Linnaeus, are the basis for the following remarks. These are wore specinens from eastern Tennessee than 
135

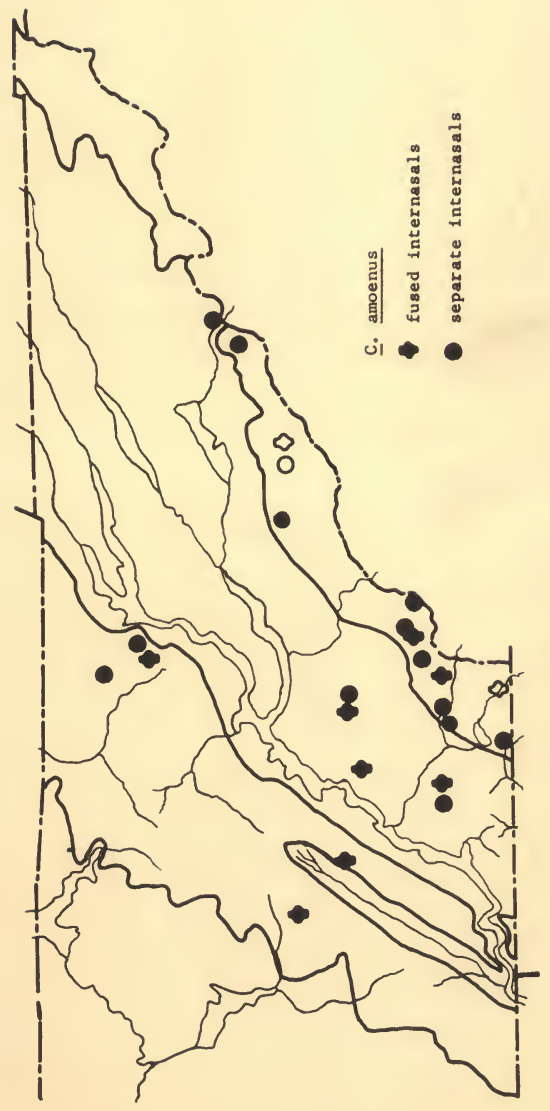


were avallable to Auffenberg (personal communication) for h1s reconsideration of this species in eastern United States (Auffenbers, 1955). These specimens range in snout-vent lengths as follows: feanales, 201 m. to $982 \mathrm{~mm}$; males, $222 \mathrm{~mm}$. to 1,122 m. Tall lengths are as follows: females, $55 \mathrm{~m}$. to $326 \mathrm{~mm}$.; males, $62 \mathrm{~m}$. to $337 \mathrm{~mm}$. Other date from these specimens are as follows: Ventrals-ofemales, range 175 (173) to 180 (178), maan 177.4 (175.5); males, range 173 (172) to 183 (182), maan 177.4 (175.1); caudals--females, range 80 to 99, mean 90.7; males, range 91 to 110, wan 97.5; supralablals, 7/6 (2 apecimens), 7/7 (19 specimens), 7/8 and $8 / 7$ (6 specimens), 8/8 (1 specimen); temporals $2+2+2 / 2+2+2$ (20 specimons), remalning 8 specimens varying from $1+2+2$ to 3+3+3; white anterior ventrale, 0 (2 specimens), 1 (1 specinan), 2 (9 specimens), 3 (6 specimens), 4 (3 specimens), 5 (1 specimen), 20 (2 specimene). Among the 11 adult males, 6 specimens have hemipenial basal hooks: 2 have one hook on each hemipenis; 4 have one hook on only one hemipenis. Among these 11 males, the ratio between length of basal spine and length of preceding spine ranges from 1.0 to 5.5 , mean 3.2 81x (21.4 percent) of the 28 males and females have the firet supralabial In contact with the loreal. As regards color, the dorsua ranges from a slaty black to black, 24 and 4 specimens respectively. The color of the venter ranges from greenish blue to black (1 epecimen). Auffenberg (1955: 93) ut1lizes two basic eriter1a in separating the various subspecles of $\underline{c}$. constrictor. These are (1) color of dorsum and venter, (2) ratio of length of basal hemipenial spine/length of next preceding apine. The colors of the dorsum of these specimens are 
within the range of variation of the Northern Black Snake, Coluber $c$. constrfetor (Linnaeus), and the Southern Black Racer, Coluber s. priapus Dunn and Wood. The color of the venter is, in the jority of the specimens, more 11ke that of the Yellow-bellied Racer, Coluber c. Elaviventris (Say). Only one opecimen has a black venter such as described for c. c. constrictor and G. c. priapus. The mean hemipental splne ratio of 3.2 is the some as that reported for specimens from cosstal llorth and South Carclina (Auffenberg, 1955: 111). Of the 6 specimens whth besel. hooks, the heabipenial spine ratio is from 4.0 to 5.5, mean 4.03. Bach of these 6 males has a white chin. Three of these 6 males have the first supralablal in contect with loresl scute. On the bass of hemspenial spine ratios, the 11 males are Intermediate between males of $\mathrm{G}$. c. constrictor and c. c. priapus.

The mean number (3.9) of white ventrals among these specimens in close to the mean value for specimens from the area of Intergradation between C. c. conatrictor and C. c. priapus in cosstal North Carolina, as are the wean number (94.1) of caudals and mean number of -ventrals 177.9 (175.2) (Auffenberg, 1955: 91, 118, 119). The conblantion of white chIn, basal hooks, and first supralabial in contact with the 10real favors C. c. priapus. These same three characters in combination with the greenish blue to blush venter suggest the influence of $\mathrm{G}$. $\underline{c}$. Elaviventris. Auffenberg, who has seen these specimens, coneurs with this latter interpretation.

of further interest, but of unknown significance, is the occurrence of black punctations on the venter of thtee of the specimens. 
Each of these punctations is the site of attachment beneath the cuticle of a mite of undeterminad 1dentification. Auffanberg (1955: 144) does not record the occurrence of such mite-induced punctations above the Cosstal Plain.

On the basis of all of the above data I conclude that the castern Tennessee $\underline{\text { c. }}$ constrictor is one of three poselble genetic conplexes. These possibilities are: c. c. conetrletor $\times$ flaviventris Intergrades; C. c. prispus $\times$ Eleviventrls intergrades; c. c. constrictor $\times$ Elaviventris $\times$ priapue 1ntergrades. I belleve that evidence presented above, plus the distributions of certaln charactars of $\mathrm{C}$. Constrictor as shown by Auffeaberg (1955: 144), favors the flrat possibility.

The lacer is widespread in castern Tennessee (FIg. 33). It does not seew to be eharacteristie of any particulax habitat as it is encountered as frequentiy in edificarlan and ruderal situations as in forest comounities. The maximum elevation of known occurrence in eastern Tennesees is 4,000 feet.

Genus Ĝjheodrys, Green Snakes. Two members of this genus are reported as occurring in eastern Tennessee; the Eastern Rough Green Snake, Opheodrys \&. aestivus (MInnseus), and the Zastern Smooth Green Snake, Opheodrye y. vernelle (larlan). Neither King (1939) nor Ash (1945) report the capture of this latter snake. Grobman (1941:15) does not Include Tennessee in the range of $\underline{0}$. $\underline{v}$ vernalis. I know of no specimens from eastern Tennessee.

Seven fomale and four male specimens of 0 . I. sestivus wre avallable. Date from the females are as follows: snout-vent length from 293 


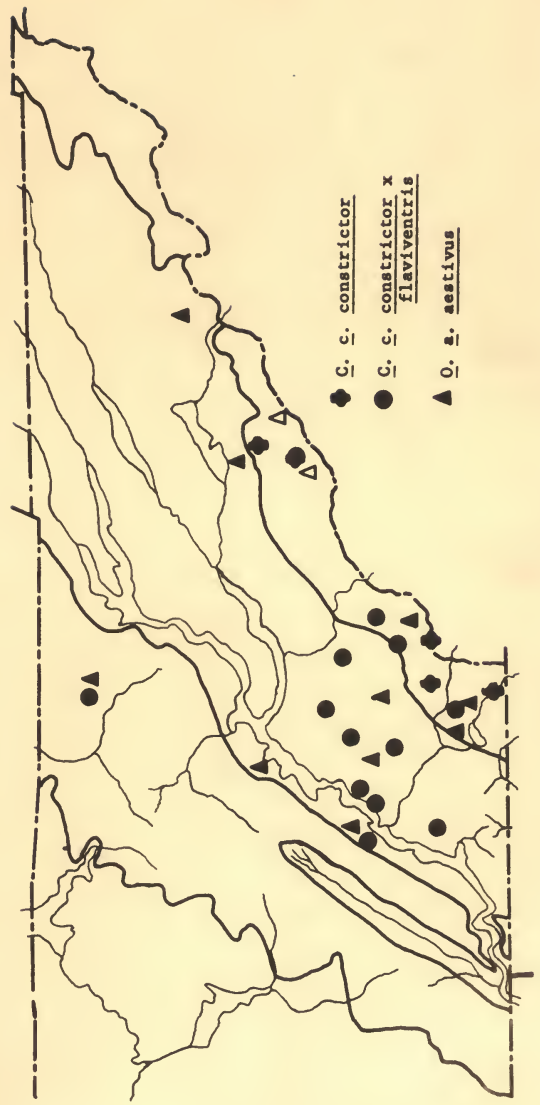

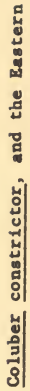

y

苂

แै

ฮี

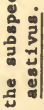

में

* ํㅣ

क्ष

잉

รี

9.

:

ค่

$\dot{\infty}$

जह

章 
mm. to $502 \mathrm{~mm}$.; tail length from $163 \mathrm{~mm}$. to $265 \mathrm{~mm}$; ventrals, range, 154 (152) to 160 (159), mean 156.1 (155.1); caudals, range 124 to 141, mean 133.3; upper labials, 7/7; lower lablals, 7-8/7-8; preoculers, 1/1; postoculars, 2/2 (6 specinens), 3/3 (1 specimen); temporals, 1+2+2/1+2+2 (2 specimens), $1+2 / 1+2$ (5 specimens). Data from the males are as follows: snout-vent length, from $343 \mathrm{~mm}$. to $455 \mathrm{~mm}$; tall length from 238 m. to $293 \mathrm{~mm}$; ventrals, range, 150 (149) to 159) (156), mean 154.8 (153); caudals, range, 133 to 139 , mean 136.3; upper 1abials, 7/7; lower lablals, 7-8/7-8; prooculars, 1/1; postoculars, 2/2; temporals, 1+2/1+2. The number of scale rows for both males and females 1s 17-15. In 11fe, this snake is 1 ime green dorsally, greenioh to yellowish white ventrally. Th1s snake is widespread in eastern Tennessee (F/8. 33). It may be encountered in a veriety of habitats from open fields to forest. It seens to be most abundent in old flelds and rarely occurs in dense mesic forest. The maximum elevation of known occurrence is 2,500 feet.

Genus Elaphe, Rat Snakes. Tvo species of Rat Snake occur in eastern Tennessee. These are the Corn 8nake, Elaphe guttata (Linnaeus), and the Rat Snake, Elaphe obsoleta (8ay). The former is represented by the subspecies Ilaphe $\mathrm{g}$. guttate (Linnaeus). The latter is an inter* gradient population between two subspecles, at least in the Valley Frovince and on the Cumberland Plateau.

Five females and 13 males of $\mathrm{g}$. \&. guttate are rather typieal of this subepecies as defined by Dowling (Ms). In general, however, this sake in eastern Tennessee is much darker than it is in the Coastal Plata. The ground color of adults is grayish brown or gray; the dorsal 
blotches are usually a dark red or brownish. The venter presents the ueual black and white checkerboard effect. One feature of the coloration, not mentioned for this snake by Dowling, but present on five of these specimens, is four brown dorolateral and lateral 11nes. These Ines are not conspleuous but are obvious. The ventrolateral IInes occupy scale rows three to five or four to s1x. The dorsolateral IInes occupy scale rows elght to eleven, nine to tulve, or nine to eleven. Length measurements from these specimens are as follows: females--snout-vent, $609 \mathrm{~mm}$. to $881 \mathrm{~mm}$.; tal1, $113 \mathrm{~mm}$. to $158 \mathrm{~mm}$; males.o snout-vent, $758 \mathrm{~mm}$. to $1147 \mathrm{~mm}$; tall, $143 \mathrm{~mm}$. to $212 \mathrm{~mm}$. The ratio between tall length and total length as reported by Dowling for this snake 1s 19.5 per cant in malee and 17 per cent in fenales. Among these specimens the mean ratios for males and females are 16 per cent and 15.7 per cent respectively. The numbers of ventral scutes for females ranges from 212 to 218, mean 216.2; for males they range from 203 to 220 , maen 213.5. The mean vilues are intermediate between the means reported for Nlew Jersey and South Carollna specimens. The mean number of caudal scales for females 1866 (range 65 to 69 ). This 18 closer to the wan value of Florida specimens than of females from north of Tennessee along the Atlantic Coastal Plain. The mean number of caudels for the males of this series is 67.4 (range 62 to 71 ). This is silghtly lese than the mean of males from southeastern Unfted States. Dorsal body blotches of the females range from 28 to 36 , mean 32.8 , and for the malee the range Is 29 to 35 , wean 32.1. These range and mean values are very atullar to those reported for specimens from the Atlantic coatal Plaln at lat1tude $34^{\circ}$. Wost of ay specimens are from between $350 x$. and $35^{\circ} 30^{\prime} \mathrm{\%}$. 
The Corn Snake is found throughout at least the southern twothirds of eastern Iennessee up to elevations of 2,500 feet. It $1 \mathrm{~s}$ most abundant in the Valley Province judging from specimens found dead on the road and otherwise collected (F1g. 34). It 18 most frequently encountered in nonforested habitats. It is not known to inhabit dense mosic foreste, but way be encountered in open oak or oak-plne forest.

The Rat Snake, Blaphe obsolate, 1s represented by 22 specimens; 5 females and 17 males. One specteen, a male, is designated as the Gray Rat Snake, Blaphe o. splloldes (Dumer11, B1bron, and Blbron); nine spec1mens, four females and fIve males, are designated as the Black Rat Snake, Blaphe o. obsoleta (Say); 12 specimens, 2 females and 10 males, ere des1gnated as ㅍ. o. obsolete $\times$ sp1loldes 1ntergrades.

The E. ․ sp1lo1des specimen, In eddition to possessing distinct dark brown dorsal blotehes on yellowish-gray ground color, hes a solld black postocular stripe and solid bleck prefrontal str1pes. Other data from th1s opecinen are as follows: snout-vent length 1,279 m.; tall length $280 \mathrm{~mm}$.; ventrals 231; caudals 86; dorsal body blotches 31; caudal blotehes 14 ; temporals $2+3+4 / 2+3+3$; scale rows one to three at mldbody snooth; scale rowe 25-27-26-25-23-21-19-17. Th1s specimen has one more dorsal body blotch than 18 reported by Dowling for E. ㅇ. sp1lo1des.

The 9 . ‥ obsolete specimens ( 3 fenales, 6 meles) have the following length measurewents: females--snout-vent from 589 to $1,250 \mathrm{~mm}$; tall from $116 \mathrm{~mm}$. to $283 \mathrm{~mm}$; males--snout-vent from 1,249 $\mathrm{mm}$. to 1,294 man.; the only tall whlch 18 complete is $250 \mathrm{~mm}$. Other data from these specimens are as follows: femeles--ventrals, range 237 to 240 , mean 


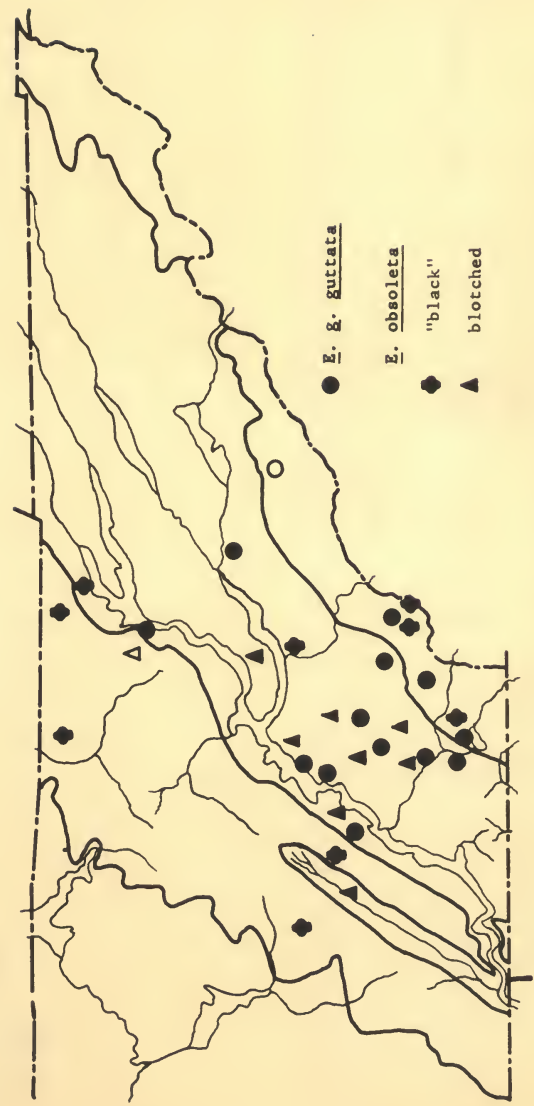

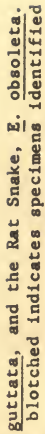

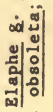

i ا

ज्ञा

ติ

당 ซ

$8 \stackrel{4}{4}$

- 4

站 亖

의

นิ -

เ ํㅗำ

-

페 긍

เี

Uू $x$

! ํㅗㄴ

:

ๆี คี

-

至 $=\dot{0}$

वे

兽 
238.7; caudals, range 76 to 81 , mean 78.5 ; dorsal body blotches (2 epecimens) 27 and 32; total tomporale, range 18 to 20 , mean 19.3; males-. ventrals, range 228 to 235, mean 231; caudsls, one specimen with complete tal1, 81; dorsel body blotches (1 specimen) 33; totel temporels, range 14 to 18, mean 16.2. Two females and four males of th1s ser1es of nine specimens are too dark to secure a dorsal body blotch count. None of these opecimens possesses a discernible prefrontal or postocular stripe. Oa each of these specimons scale rows one and two at midbody are omooth.

The twelve specimens (2 femeles, 10 males) designated as E. O. obsolete $x$ sp 1lofdes Intergrades have the following esesurements: females--snout-vent, $829 \mathrm{~m}$. and 1,250 ma.; tall, not measured, Incomplete; males--snout-vent, from $620 \mathrm{~mm}$. to $1,421 \mathrm{~mm}$; t tell, from $135 \mathrm{~mm}$. to 271 mas. (I question the value of tall length messurements because of the frequency with which they are incomplete and the lack of ablitty to pos1tively detect regenereted (alls.) Other data fron these specimens are as follows: fomales--ventrals, 232 and 234; caudels, not counted because of Incomplete talls; dorsal blotches 30 on one, too indistinct on the others; totel temporals 17 ; males--ventrals, range 230 to 239 , wean 232.3; caudals, range 83 to 87 , waan 85.1 ; dorsal blotches, range 28 to 34 , wean 30.6 ; total temporals, range 13 to 26 , mean 18.2 . Each of these specimens possesses a blotched dorsal pattern, though it is too Indiatinct to count on one female and three of the males. The blotches range in color from purplish-brown to dark brown or black. The ground color varies frow 11ght gray through brownish-gray to dark brown. Mone of these possesses a discernible prefrontel stripe. Four of then possess a postocular stripe. 
Of the 22 spacimens, 11 but the ․․․ 오loldes and one of the Intergradas possess 25 scale rows at midbody. The exceptional intergrada has 27 scale rows. Mine specimens (4 ‥ ‥ obsoleta, 5 E. ㅇ. obsolete $x$ sp1lo1des) have a scala row formula of 25-27-25-23-21-19; 4. ‥ obselete and 5 E. ㅇ. obsolete $\times$ splloldes have a seale row formula of 25-27-25-23-21-19-17; 2 …ㅇ. obsolete and 1 Intergrade spec1men have scale row formulae of 25-23-25-23-21-19-17. Conant (1939: 56) states that 17 is the noral ainimal nubber of dorsal scale rowe in $\mathrm{E}$. o. obsolets in Ohio.

Dowling (US) does not discuss dark dorsolateral and lateral lines except In the Yellow Rat Snake, Elaphe o. quadrivittate (Holbrook). Net11 (1949: 3-4) regards the presence of thase 11nes on darik B. O. obsoleta-like specimens in Georgle es evidence of intergradation between this subspecies and $\underline{E}$. ‥ quadrivittata. I cannot subscribe to this Interpretation of these 11 nes on such specimens as indicating intergradation between these two subspecies. I know of numarous specimens of "good" E. O. obsolete from Ohio and West Virginie which have these 11 nes. Furthar, these 11 nes can be seen on 13 of the 22 specimens of $\mathrm{g}$. obsoleta from eastern Tennessee.

On four of the ㅍ. ㅇ. obsolete specimens the dorsolateral Ines occupy rows nine to eleven (1 specinen), rows ten to twalve (2 specimans), and row ten to thirteen (1 spacimen); the leteral Ities occupy rows one to five, rows one to six, rows two to six, and rows three to s1x on these specimens. On the ㅍ. ㅇ. sp1lo1des specimen these 11nes oc* cur on rows alne to eleven and rows threa to five, respectivaly. Among 
the Intergrade specimens, the distributions of these lines are as follows: dorsoleteral 11nes---sows nine to eleven (3 specimens), rows ten to twelve (9 specimens); lateral 11nes--rowe two to five (1 specinen), rows two to six (2 specimens), rows three to six (6 apecimens). AccordIng to Dowling, ‥ ㅇ. guadrivittate has the dorsoleteral lines on rows ten to twelve and the leterel 1 ines on rows three to five. Blven of ay specimens (2 ㅌ. ㅇ. obsolete and 9 Intergrades) have the dorsoleterel Iines on rows ten to twelve es reported for g. o. quadrivittata. Only the I. 2. spllotdes specimen has the laterel line on rows three to five. Because of the presence of these lines on individuals of $\mathrm{E}$. 0 . obsoleta subspecies other than ㅍ. ㅇ. quadrivittapa, and, es mentioned ebove, on E. I. guttake, I wonder if the lines par se may not be older then any of the subspecies of the obsolete complex. Instead of the presence or absence of the lines being of subspecific diagnostic velue, the distribution of the lines may be a subspecific cheracter.

All of the intergrede specimens and the $\mathrm{z}$. ‥ gplloldes are from the Velley Province south of the letitude of Knoxville, the Cunberlend Plateau south of the Cumberlend Kountains section, or from beLow en elevetion of 1,200 feet in the Unaka Province (Fig. 34). Oceasional opecimans 1dentifieble es $\mathrm{E}$. O . obsolete may be encountered in the Velley, but the majority of such specimens secm to be confined to the higher elevations of the Unaks Hountains, to the Valley north of the letitude of Knoxville, and to the Cumberland Mountains section of the Cumberlend pleteau Province. This distribution is similar to thet of the subspecies of Natrix sipedon in eastern Tennossee. 
The Rat Snake 1 s essentially a woodland animal. All of the specimens which I have excountarad in the Unaka Mountains have been in dense mesic dec1duous forast. In the Valley and on tha Plateau this snake is not uncommon in agrarian situations, perforce because agriculture is much more intansive in these two areas than in the mountains. The maximum elavation of known occurrence of this snake in eastarn Tennessae is 4,000 feet.

Genus P1tuophis, P1ne Snakes. The Northern P1ne Snake, Pltu-

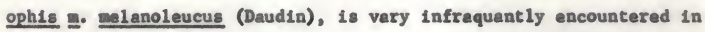
eastarn Iannessae. Ash (1945: 263) reports the collection of two Ind1viduals in the Copparhll1 area of Polk County. Highton (personal communication) Informs ma of a large specimen dead on the road which he saw near Chllhowee, Blount County. Stull (1940: 59-60) reports two from eastern Tennessea; one from knox County, one from Blount County. Th1s snake 18 also known from the Abrams Craek araa of tha Grat Snoky Mountalne National Park. I an Informed by varlous persons that this snake is rather abundant on the Cumberland Plataau and as far west as Benton County, which 11 es partly in the HIghland RIm and partly in the Missisippl embayment of the Gulf Coastal Plaln.

Only two spacimens are avallable for axanination. One is a juvanile femala frow the Cumberland front in Rhea county. The other is a wale from Polk County. The following data are from the fenala: snoutvent length $595 \mathrm{~mm}$.; tall langth $72 \mathrm{~mm}$; ventrals 212; caudals 51 ; scala rows 27-29-21; supralabials 7/8; Infralablals $12 / 11$; 1 oraals $1 / 0$; no azygous scala; dorsal body blotches 34; tall blotches 6. Data from the 
male specimen are es follows: snout-vent length 1,300 an.; tall length 190 m.; ventrals 217; caudals 58; cale rows 27-29-21; supralablals $8 / 8$; Infralabials $12 / 12$; loreals $1 / 1$; azygous seale present; dorsal body blotches 29; tall blotchas 6 .

The female is a brown-apotted snake. The dorsal blotchas are rectangular with the long axis transverse to the body axis, rather than belng quadrangular. The median series of lateral blotehas on the right side is replaced by a continuous line from the neck to the tall. On the left sida this line is broken into elongate dashes on the posterior two-thlrds of the body. Thare is a definite tendency for the dorsal spots to be in two series. One series, consisting of the large rectangular blotches, has the antarior and posterior corners of these spote projecting forward and posteriorly to meet similar axtensions from adJacent blotches. The result is an H-shaped pattern. Between the projecting arms of the larger spots is a smaller circular spot. This pattern occurs on the anterior and posterior thirds of the body. The color pattern of this snake 18 suggestive of the color pattern of the

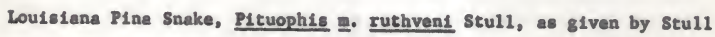
(1940: 74,76).

The male specimen has dark brown dorsal spots on an Ivory ground rather than black spots on a white ground. The ground color of the dorsum 1s distinctly darker than that of the lower sides. Ash (1945: 263) reports that his specimens have brown spots on allowish ground color. Thase variations of coloration may be within the range of variation of P. ‥ elenoleucus. Present on this snake, but not recorded for any of the spectmens exanined by stull, is an azygous scale. 
In number of ventrals, caudals, and labials, these two specimens are closer to a Cosstal Plain series than to a mountain series d1scussed by stul1 (1940: 58).

Although not abundant, this snake is evidently widespread in eastern Tennessee (F1g. 35). Locallties from which specimens are known vary from open pasture land to floodplain forest to mesic oak-hickory forest. The majority of my records indicate that this snake is an inhabltant of deciduous or deciduous-pine forest. I have no records of specimens from xerle oak or oak-pine-heath communities. Too few specimans are avallable for adequate habitat generalizations. The maximum elevation of known occurrence 18 1,900 feet.

Genus Lempropeltis, Kingenakes. Three species of kingsnakes occur in eastern Tennessee. These are the Fralrie Kingsnake, Lanpropeltis calligaster (Harlan), the Comnon Kingsnake, Lampropeltis getulus (Winnaeus), and the Milk Snake, Lapropeltis dollata (Linnaeus).

The Mole Snake, Lampropeltis c. rhombomaculata (Holbrook), is represented by four female and $s 1 x$ male spectmens. Data from these specimens are as follows: females--snout-vent length from 213 mm. to $700 \mathrm{~mm} . ;$ tall length from $32 \mathrm{~mm}$. to $93 \mathrm{~mm}$; ventrals, range 198 (197) to 209 (207), wean 203.3 (201); caudals, range 40 to 44 , mean 42.5 ; dorsal body blotches (plus tall blotches in parentheses), range 40 (51) to 43 (57), mean 41.7 (53.3); males--snout-vent length from $214 \mathrm{~mm}$. to $792 \mathrm{~mm} . ;$ tall length from $31 \mathrm{~mm}$. to $86 \mathrm{~mm}$. (male with largest snoutvent measurement with incomplete tal1); ventrals, range 197 (195) to 206 (204), mean 201.7 (199.8); caudals, range 44 to 48 , mean 45.5 ; 


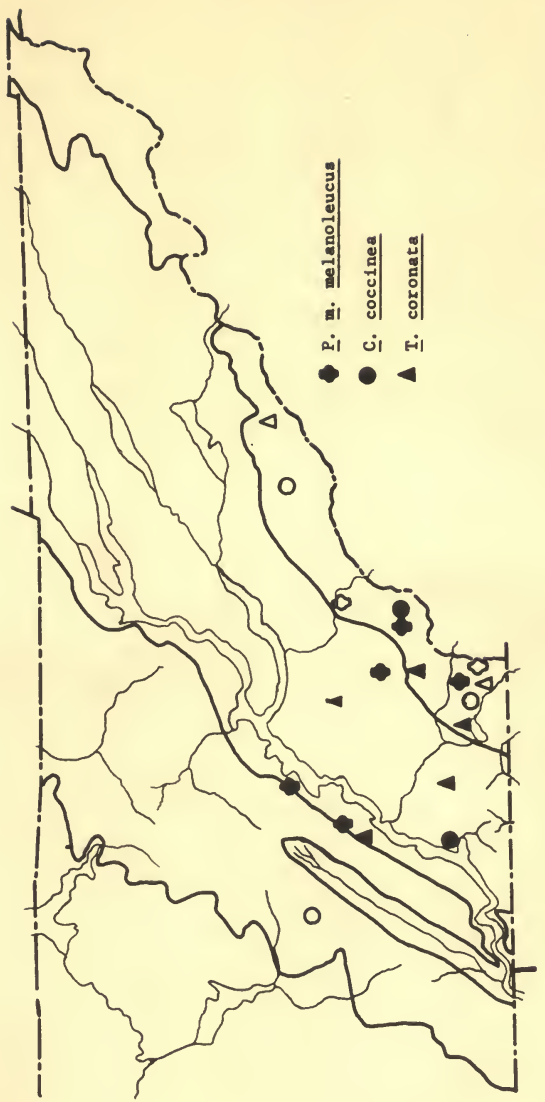

है

选

ปู่

히

离

해ㅇㅝㅠ

원

㟔 루

苟

!

กิ

๘

है 
dorsal body blotches (plus tail blotches in parentheses), range 40 (50) to $43(54)$, mean 41 (52.8); seres combined--uper 1ab1als 7/7; 1ower lablals, 9/9 (5 specimens), 9/8 (3 specimens), uncountable in 2 spec1mens; temporals, $2+3+4 / 2+3+4$ ( 6 seclmens), $2+3+3 / 2+3+4,2+2+4 / 2+3+4$, $2+3+4 / 2+3+5,2+3+3 / 2+3+7$ (1 specimen each); scale rows, 21-19 (5 spec1mens), 21-19-17 (2 spec1mens), 21-23-21-19, 19-21-19-17, 23-21-19 (1 specimen each). As regerds dorsal blotch counts, only three females and four males have patteras distinct enough for accurate counts. As ragards these characters and coloration, these specimens are not different from the description of $\underline{\text { s. }}$ c. rhombonaculata as given by Blanchard (1921: 128-134).

This snake is apparently confined to the Valley Province and the lower levations in the Unake Province (F1g. 36). It is character1stic of the cleared agricultural areas but may be encountered in open oak or oak-plne combunities. The maximum elevation of known occurrence is about 2,000 feet.

The Common Kingsnake 18 represented by a serles of five females and ten males. Data from these specimens are as follows: fearales-o snout-vent length from $232 \mathrm{~mm}$. to $729 \mathrm{~mm}$; tall lengthe from $31 \mathrm{~mm}$. to 119 mm.; ventrals, range 202 (201) to 212 (212), mean 206.4 (205); caudale, range 40 to 49, man 45; crossbande on body (plus tall crossbands In parentheses), range 24 (33) to 36 (45), mean 30.3 (37.5); number of alternating 11 ght and dark spaces on side of the body on scale row I, range 30 to 45.5, mean 34.3; males--snout-vent length from 569 mo. to 1,045 m.; tall length from $87 \mathrm{~mm}$. to $156 \mathrm{~mm} . ;$ ventrals, range 

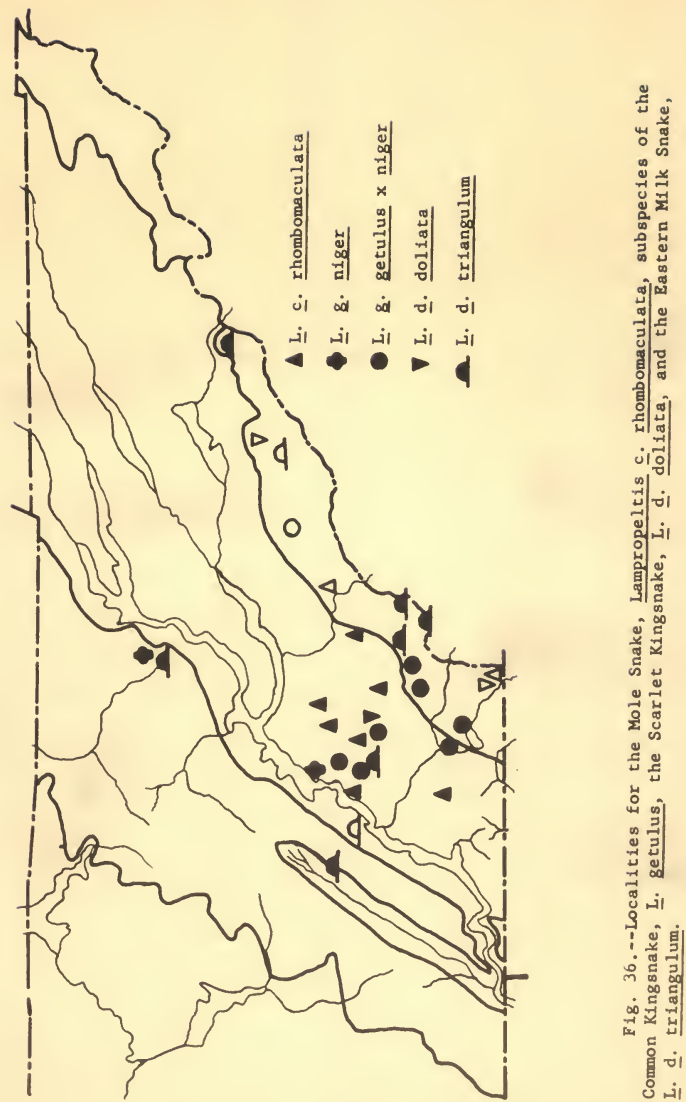
200 (198) to 212 (211), mean 206.6 (205.2); caudals, range 44 to 54, mean 44.2; erossbands on body (plus tall erossbands in parantheses), range 25 (34) to 52 (66), wean 35.8 (41.7); number of alternating 11ght and dark spaces on scale row I, range 27 to 78, mean 46.2; sexes combined-upper lablals, 7/7 (15 spectmens); lower labials, 8/9 or 9/8, 10/10 (2 specimens eech), $9 / 9$ (10 opecimens); temporals, $2+3+4 / 2+3+4$ (11 specimens), $2+1+3 / 2+2+3,2+1+4 / 2+2+4,2+3+3 / 2+3+3,2+3+4 / 2+3+2$ (1 specimen each); preoculare 1/1 (15 specimens); postoculars 2/2 (15 spectmens); scale rows, 19-21-19 (1 specimen), 21-19-17 (2 specimens), 21-19 (12 opecimans).

When these data are compared with the descriptions in Blanchard (1921) of the Bastern Xingsnake, Lampropletis \&. getulus (Linneeus), and of the Black Kingsnake, Lampropeltils g. niger (Yarrow), the conclusion 1s reached that eastern Tennessee $\underline{\underline{L}}$. getulus sre intermediate between these two subspecies. Only two specimens appesr to be "typleal" L. g. niger. One of these is from the Cumberland Hountifin, the other is from Maigs County near the Tennessee River. The besis upon which 13 of these specimens are designated as L. g. getulus $\times$ ntger intergredes Is as follows (data for each of the subspecies are from Blanchard): number of crossbands on the back, range 29 to 51 , wan 41.7 (L. g. gatulus, range 23 to 48 , mean 35.8 ; L. g. nigex, range 50 to 86 , maan 65); number of alternating 11ght and dark exeas on lower sides, range 27 to 50, mean 36.9 (L. I. getulus, with as few as 33); a anfority of the opecimens with scale rows 21-19 and the 11ght doreal crossbands as weh as one scale vide (L. \&. getulus characters). King (1939: 573) reports 
evidence of Intergradation of these subspecies in the Greet Spoky Mountains Mational Park. Thus, the zone of Intergradation between these two subspecies Includes eastern Tennessee.

Although not of uncomnon occurrence in the agricultural Valley Province, the Comnon Ringenake is more frequently encountered in the Unake Province (FIg, 36). This I belleve is e result of its predelletion for a woodland habltet. Iven in the Valley, the mejority of opecimens are encountered in the vicinity of wooded atream valleys. The meximum elavation of known occurrence in eastern Tennessee is 2,500 feet.

Wo subspeciee of the Milk Snake ara present in eastern Tennessee. These ere the scarlet Xingenake, Lampropeltis d. dolieta (Linnaeut), and the Eastern Milk Saake, Lampropeltile d. trlengulum (Lacepede). Ring (1939: 573) reports - specimen of the Coestel Plain Milk Salke, Lanpropeltie elapsoldee virginle ( $\mathrm{L}$. I. dollete), from the Greet saoky Mountains. Conant (1943; 20) regerds th1s specimen es ㄴ. $\mathrm{E}$. elapeoldes (- L. d. dollete). Conant restricte L. d. dollata to the coestel plein end Pledmont and L. d. triangulum to the mountains. Subsequent to Conant's paper, Ash (1945) reports e single specimen from an elevetion of 1,400 feet in Polk County. Blanchard (1921: 216) reports a epecimen from Knoxvilla, Rnox County. An edditional specimen 1s eveilable from Athens, Marunn County. Further, I an Informed of the occurrence of L. d. dollete froa the vicinity of Blueridge, Fannin County, Georgie, where it is known locelly es "corel snake." The elevation of slueridge 1s 1,800 feet. 
The single $\underline{\underline{z}}$ d. doliate is a male with a snout-vent length of $392 \mathrm{~mm}$. and a tall length of $67 \mathrm{~mm}$. Other data from thls specimen are es follows: ventrals 169; caudals 38; upper 1abials 7/7; lower labials 9/9; anterior temporals $2 / 1$; loreals 0 ; 16 red bands on the body. In these characters and in coloration, this specimen agrees with the description of the subspecies $\underline{\text { L. }}$ d. dollata as given by Blanchard (1921: 207-209) and by Conant (1943: 7-8).

The subspecies L. d. trisngulum is represented by four females and five males. Data from these specimens are as follows: females-snout-vent length $192 \mathrm{~mm}$. to $638 \mathrm{~mm}$.; tall length $30 \mathrm{~mm}$. to $100 \mathrm{~mm}$. ; ventrals, range 202 (201) to 205 (204), mean 203.8 (203); caudals, range, 43 to 48, mean 46; dorsal body blotehes, range 32 to 41, mean 35.5; asleg--snout-vent length $184 \mathrm{~m}$. to $730 \mathrm{~mm}$; : tall length $30 \mathrm{~m}$. to $60 \mathrm{~mm}$. (the tall of the largest male is incomplete); ventrals, range, 198 (197) to 207 (205), man 203.2 (201.8); caudals, range 46 to 49 , mean 47.7; dorsal body blotches, range 31 to 41, mean 36.4; sexes comblned--geale rows 21-19 (4 specimens), 21-19-17 (5 specimens); upper lablals $7 / 7$ (9 specimens); lower 1ablals 8/8, 9/10, 10/10 (1 specimen each), 9/9 (6 specimens); snterior temporals $1 / 1$ (2 specimens), 2/2 (7 specimens); three series of dorsal spots on 7 specimens, five series of doreal spots on two specimons. All of these characters are within the range of variation reported for $\underline{L}$. d. triangulum by Blanchard (1921: 190-192, 197-202) and by Conant (1943: 6-7). In color and color pattern these specimens are aleo like the descriptions cited above.

Conant (1943: 20) states that ㄴ. d. triangulum and ㄴ. d. dollata are not known to occur in the same locallty. The inference from this 
discussion is that at least on the North Carolina side of the suoky Mountalns ‥ d. triangulun and ‥ d. doliate are altitudinally seperated from each other. In eastern Tennessee locality records for these two subspecies show that the elevations of occurrence of these two snakes

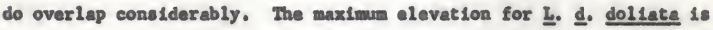
1,800 feet; the minimum elevation for ㄴ. d. trianglua 18900 feet, and this in Mclinn County from whence a specimen of ㄴ. d. dollate is known (F18. 36). That these two snakes may occupy quite different ecologicel eltuations is possible. The known maximum elevation of occurrence of L. d. triangulun is 4,600 feet. Thls snake 1s definitely associated with deciduous forest communities. None of my records indicates that 1t 1. found in the more reric oak or oak-pine coumunities, and none of the records is assoclated with cleared agricultural land.

Cenus Cemophore, Scarlet saake. Oniy two specinens of this snake are avallable. One 1s a mutilated specimen fron Imiliton County, the other is from Monroe County (Fig. 35). King (1939: 574) records a single specieen from Cades Cove in the Great Smoky Hountains Mational Rerk.

Of 4 specimens, only the Honroe County specimen is in a condition perndteting the collection of data. Thase data are as follows: snout-vent length $321 \mathrm{ma}$; tall length $59 \mathrm{ma}$; ventrals 157 (155); caudals 43; supralablals $6 / 6$; Lover labials $7 / 7$; temporals $1+2 / 1+2$; preoculars 1/1; postoculars 2/2; red saddles on body 17; red saddles on tall 4; 11.ght bands on body 16; 11 ght bands on tall 5; scale rows 19. In preservative, the scales of the 11ght bands and the light lateral areas 
ere grayish with centers stippled with brown. The venter is cream colored. In ell respects this specimen does not eppear different from the descriptions of the Scarlet Snake, Cemophore coceinee (Blumenbach).

Both of my specimens are from locelities edjecent to hardwoodpine forest with an herbaceous understory. The inference is that this snake is an inhabitent of mesic forest. The maximum elevetion of knorga oceurrence is 2,000 feet.

Genus Tantilla, Black-heeded Snakes. Five females and one male of the Crowned Snake, Tantilli coronata Beird and Girard, are avellable. Date from these epecimens are es follows: females--snout-vent length $174 \mathrm{~mm}$. to $242 \mathrm{~mm}$; tell length $33 \mathrm{~mm}$. to $57 \mathrm{~mm}$; ventrels, range 142 (139) to 151 (148), mean 145.2 (142.6); ceudals, range 42 to 46 , man 43.2; male-monout-vent length $207 \mathrm{~mm}$; tali length $41 \mathrm{m.j}$; ventrels 139 (136); ceudals 41; both sexes-mscale rows 15; upper lablels $7 / 7$; lower lebials $6 / 6$; postoculars $2 / 2$; tenporels $1+1 / 1+1$; width of collar at midline in terms of scele lengths, renge 2.5 to 4 , ween 3.2 ; the 11 ght band crossing the posterior tips of the perietel scutes ranges from less than one scele wide in one specimen to two scales wide in one spectmen.

Comparison of these data with deta presented by Schwarts (1953) indicates thet intergredation between the Southeastern Crowned Snake, Tantiells c. coronate Beird and Girard, and the Appelechian Crowned Snake, Tantille c. mitrifer Schwarte, occurs on the western slope of the Southern Appalechian Mounteins. It is of interest to note that the data presented above are fros two specimens from the Cumberland Pleteau, two 
specimens from the Valley Province, and two spacimens from the Unaks Province. The point of interast is that four of the specimens which possess characters intermediete between I. c. coronate and I. c. Mitrifer are from well outside the 1imits of distribution of the letter subspecies as defined by sehwartz. I wonder $1 f$ the characters used by Schwartz for d1agnosing I. c. m1trifer might not be within the range of

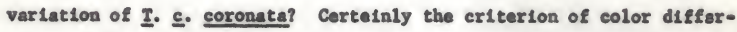
ences in preservative is a questionable one.

Locallty data for these opecimens indicete that this snake is most abundant In the Unaka Province (IIg. 35). The known maximus elevation of occurrance in eastern Tennessee is 1,800 feet. Th1s snake is epparently restricted to woodland, and most spectmens are from oak-pineheath communities with rether loose sandy to loany solls. This latter condition 1s probebly a requisite for their fossorial habits.

\section{Fanily Crotalidee}

Genus Ancistrodon, Copperheeds and Cottonmouths. One specles of this genus, the Copperhead, Anctstrodon contortrix (Linneeus), 1s presant in eastern Tennessee. The bellef is prevelent among the people of this area that the Cottonmouth, Ancistrodon plsctvorous (Lacèpéde), is found in eastern Tannessee. I have bean unable to discover this snake, nelther ara thara literature racords of 1 ts occurrence here.

Thirteen females and seven males of $\Lambda$. contortrix are avalleble for examination. Data from these specimens are es follows: females-snout-vent length $492 \mathrm{~mm}$. to $699 \mathrm{~mm}$.; tall langth $74 \mathrm{~mm}$. to $88 \mathrm{~mm}$.; ventrals, range 149 (147) to 154 (153), mean 150.3 (148.6) caudals, range, 
42 to 48 , mean 45.3 ; body beads, range 14.5 to 18.5 , man 16.1 ; males.snout-vent length $537 \mathrm{~mm}$. to $811 \mathrm{~mm}$; tall length $85 \mathrm{~lm}$. to $124 \mathrm{~mm}$.; ventrels, range 149 (147) to 153 (152), man 151.1 (149); ceudels, range 44 to 49 , mean 46.9 ; body bands, range 16 to 18 , mean 17.1 ; sexces combined--scale rows, 23-21-19 (4 specimens), 25-23-21 (2 specimens), 2725-23-21-19 (3 specimens), 27-23-21 (1 specinen), 25-23-21-19 (10 spec1mens); upper lablels, $7 / 7$ (5 specimens), $7 / 8$ or $8 / 7$ (3 specimens), 8/8 (11 specimens), 9/8 (1 specimen); lower lablels, 9/9 (5 specimens), 9/10 or 10/9 (7 specimens), 10/10 (8 specimens). All specimens, regardless of scale count formulee, heve 23 acele rows at midbody. The ranges of the above characters are withln the varletion reported by Gloyd and Conant (1943: 168) for the Northern Copperhead, Anctstrodon c. mokeson (DaudIn).

The color of these specimens agreas essentially with that given by Gloyd and Conant for A. c. mokeson. Bach of these specimons hes the dorsum and venter stippled with dark brown or gray. Dorsally, this stippling is wost intense on the ground color between the bands. Ventrally, it is most intensive postariorly end often elong the lateral edges of the venter. The latter condition results in the eppearance of a IIght midventrel streak. Each specimen 1 lso possesses paramedian, 1rregularly sheped dark apots on the ground color between the dorsal crossbands. These paramedian palrs of spots are most frequent at midbody or posterlor to the midbody region. These color pettarns are withIn the range of variation for $\underline{A}$. ‥ mokeson.

The copperhead is widespread in eastern Tennessee (Fig. 37). Collection sites vary fron dry, rocky ledges to heevily timbarad and 


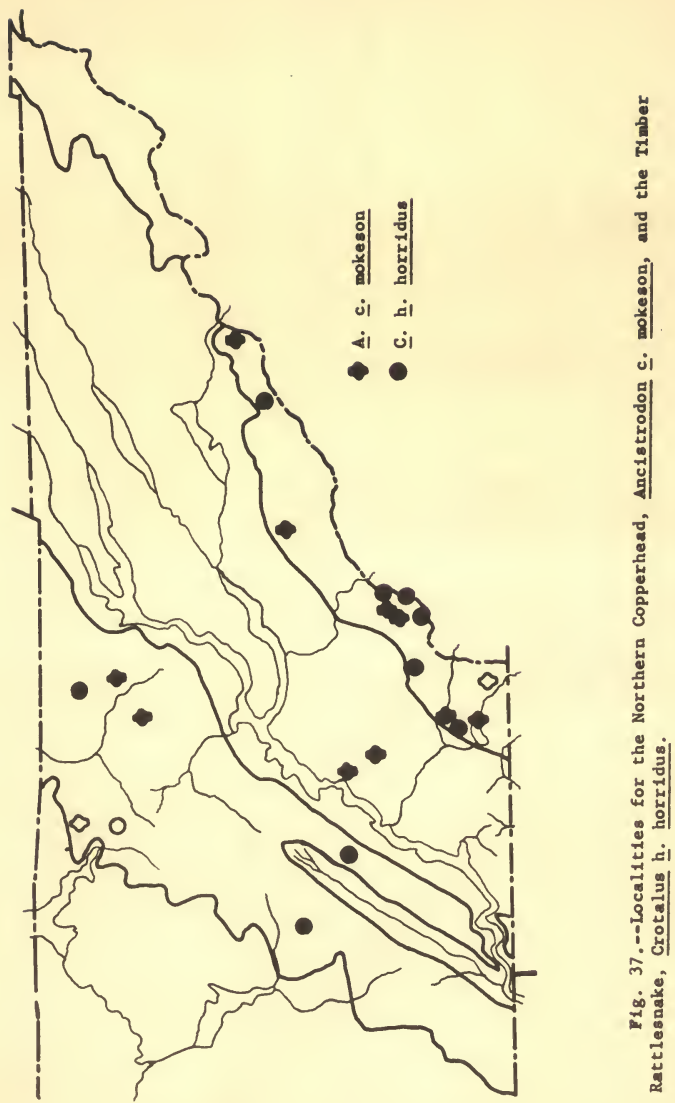


deciduous floodplain comunities. In each case, however, the collection site is in or near forest land. The maxinum elevation of known occurrence is 3,000 feet.

Genus Crotalus, Rattlesaakes. Only the Timber Rattlesnake, Crotalus h. horridus Linnaeus, is present in eastern Tennessec. Some members of the populace, particularly in the Cumberland Mountafn Section, refer to " "black diamond rattler." I can only infer that they have reference to the black phase of $\underline{\mathrm{c}}$. $\mathrm{h}$. horrldus. In a fishing supply store In Nalge County there is the skin of the Iastern Diamondback Rattleanake, Crotalus edamanteus Beauvo1s. The proprietor says the opecimen 1s frow the Cumberland Plateau in Marion County. Undoubtedly, this specimen 18 an escapec.

Only four females and two males of C. h. horridus are avallable. Data from these specimans are as follows: fensles-ornout-vent length $695 \mathrm{~mm}$. to $848 \mathrm{~mm}$. ; tall length $44 \mathrm{~m}$. to $55 \mathrm{~mm}$.; ventrals, range 168 (164) to 176 (174), mean 170.5 (167.2); caudals, range 17 to 22, mean 20.8; body blotches and crossbands, range 22 to 25 , mean 23.2; males-snout-vent length $827 \mathrm{~mm}$, and 1,006 m.; tall length $65 \mathrm{mn}$. and $80 \mathrm{~m}$.; ventrals 166 (163) and 167 (165); caudals 24 each; body blotches and erosebands 22 and 24; sexes combined-escale rows, 25-23-19 (5 specimens), 26-23-19 (1 specimen); upper labisls, 13/14 or 14/13, 14/15 or 15/14 (2 specimens each), 14/14, 15/15 (1 specimen each); lower lablals 14/14, $15 / 14,14 / 16,13 / 15$ (: specimen each), 16/15, 15/16 (1 specimen each). One female is nearly black, although the dorsal pattern of the blotches and crossbands is clearly discernible. One male is sulfur 
yellow between dark brown to black blotches and crosabands. The renainIng specinans are gray Lah with dark brown to black blotehes and crosebands. Each of the females has a adian dorsal brown stripe which occuples the madien and adjacent halves of the dorsal scale rows. This stripe is not discernible on the ales.

In matters of scutellation and coloration, these specimens are withln the range of variation for C. h. horridus as reported by Gloyd (1940: 180-183).

Although wldespread in eastern Tennesee,, I have not encountered the Timber Rattlesnake in the Valley Province (TIg. 37). I have been told of its oceurrence on some of the more renote knobs in the Val1ey. Some of the knobs and ridges are nanad Rattlesnake RIdge or Knob. Undoubtedly the rattlesnalce formerly occupled all sultable habltats in eastern Tennessee. I do not believe that it is lack of suitable hab1tat whlch now 18 responsible for 1 ts apparent absence from the Valley and restriction to the remote ridge and mountain tops. Rather, I am convinced it is so restricted as a result of the enmity of man. The rattlesnake is a forest Inhabitant, though the types of forest inhabited range from northern hardwoods on the moutain tops to rerlc oak and oakpine-heath forests on the southern slopes. The maximum elevation of known oceurrence is 5,500 feet. 


\section{DIscussion}

\section{A. Herpetofeunal Assemblages}

Cain (1944: 164) proposed the grouping of floriste lemonts of a territory Into Intraneous and extraneous specles, "according as thair occurrence in thet territory is well withdn the area of the form or near the periphery of its area, respectively." I have eaployed these concepts in the analysis of the herpetofauna.

Bastern Tennessee 18 well whthin the known range of some of the anphiblens and roptiles and near the periphery of the known range of others. Those amphlbians and reptilos having known ranges extending far beyond the borders of eastern Tennessee are deslgnated as Intraneous forms. Those apphiblans and reptiles in eastern Tennessee which are near the periphery of their respective known ranges are designated as extraneous forme. Among the extraneous forms, I an recognizing three different categories; western extraneous, northern extraneous, and southern extraneous. Western extraneous forms are those having the greater portion of their ranges extending westward across the Mississ1ppl River and/or northwestward Into Indlana, IIIInols, and beyond. The eastern periphery of their respective ranges is in or imadiately east of eastern Tennessee. Northern extraneous elements are those which have the greater part of thelr ranges extending northward Into Indiana, Oh10, and the North Atlantic States. The southern periphery of the ranges of these forms is in or Imadiately south of eastern Tennessee. 
The southern extraneous form ere those which bave the greater part of their respective ranges to the south and southeest. The periphery of their respective ranges is in or Immedletely north of eastern Tennesee. In eddition to the above cetegories, I an recognising e group termed endemic forms. These have their known ranges restricted to the imediete vicinity of, but not necesearliy within, eestern Tennessee. The anphiblans and reptiles asalgned to each of the above five categorles are presented in Table 1. Excluded from the listings are Yecturus, siren, and Ambystona t1grinum.

To deternine the known ranges of the anghlblans and reptiles, I heve consulted the following sources: salamanders, exclusive of the genus Plechodon, Bishop (1947); the genus Plethodon, Highton QtS); anurans, exclustve of the specles Rans clamitans, Wright and Wright (1949); species ‥ clamitans, Mechum Qus); turtles, Carr (1952) and Cagle (1953): 11zards, exclusive of the genus Ophisaurus and the species sumeces anthracinus, Satth (1946); gemus Ophlsuarus, McConkey (1954); spec1es E. anthracinus, Salth and Senth (1952); nalkes, exclusive of the gemus Elaphe and the apecies Coluber constrictor and Tant11la coronsta, Wright and Wright (1957); genus Blaphe, Dowling (aS); species C. constr1ctor, Auffenbers (1955); spec1es I. coronata, Schwartz (1953). The known ranges of some anphibiens and reptiles have been extended se a result of this atudy. These are: Burycea 1. Buttolinenta; Scaphlopus h. holbrook1; Preudacris n. txisertata; Rana R. aphenocephala; Graptenys R. ouch1tene1s; Natrix s. Pleuralis; Diadoph1s R. punctatus; Coluber c. Ilaviventris; Slaphe o. sp1loldes. 


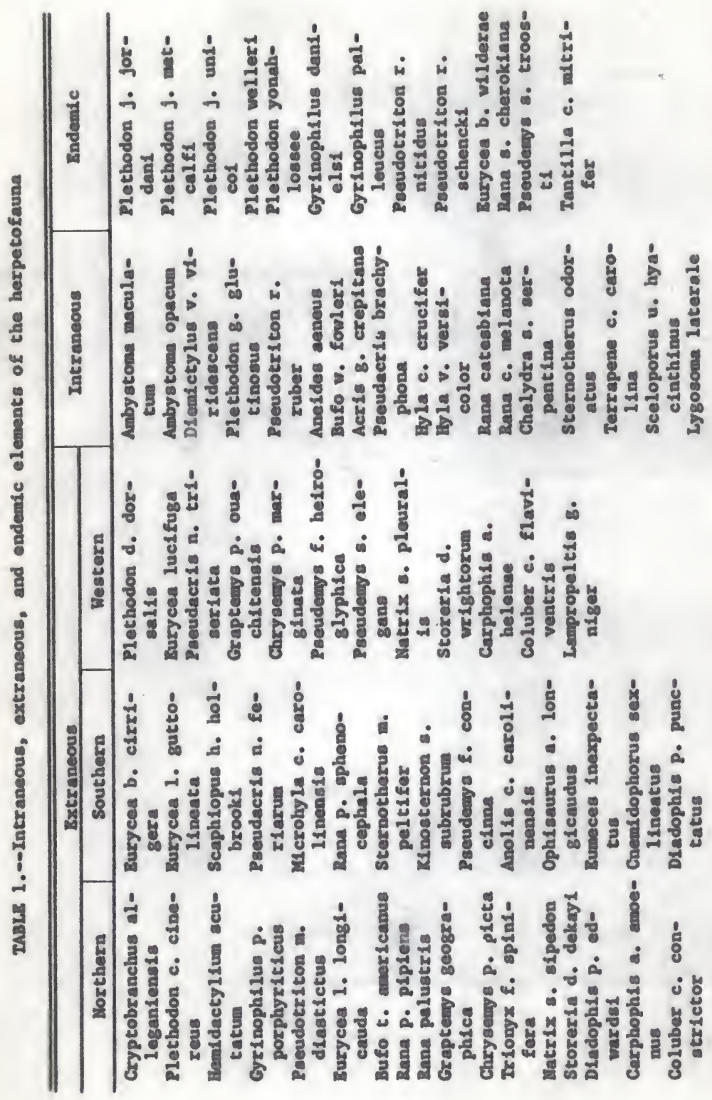




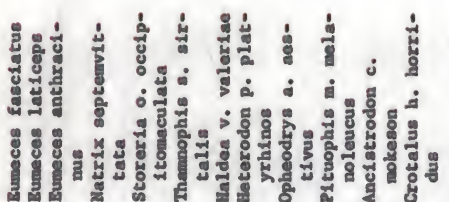

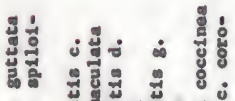

कं

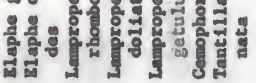

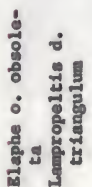

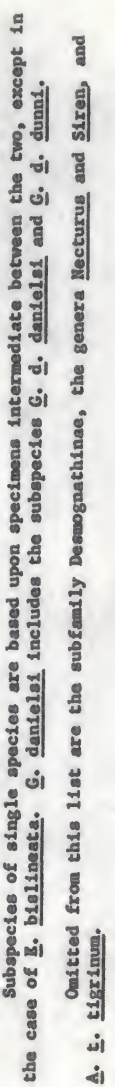


A totel of 95 species and subspecies is 11sted in Table 1. Of this number, 52 ere designated as extreneous; 12 vestern, 19 northern, and 21 southern. Among the 13 forma considered endemic, 9 are salamanders. All except two of these nf ne salamenders are restricted in eastern Tennessee to the Unaka Hounteins Province. The two exceptions ore Grrinophilus palleucus, restricted to the type locelity in the Cumberland Pleteau Province, and G. deniels , which extends westward ecross the northorn part of the Velley Province to the Cumberland Mountelns (Bishop, 1947: 362). The endemic frog and snake are of questionable vel1d1ty [Muaphreys (1n 11tt.) and Wright and Wright (1957: 732), respectively]. But, as presently recognized, both are restricted in eestern Tennessee to the Unaka MountaIns Province. The turtle, P. S. troost1, 1s restricted to the upper reaches of the Cumberland and Tonnessee rivers (Carr, 1952: 241). Thirty forms are designated as 1ntreneous. Of these, eleven are monotypic species. Of 67 extraneous and endenic specles, only 9 are monotypic.

The distributions of the various assemblages are of considerable Interest (Tables 2 and 3). The blank speces and onlssions of names under the varlous physiogrephic sections may be interpreted es indicating the ebsence from these areas of the forms in question. However, this may be the result of Insufficient knowledge of their distributions. I have more confidence in the implicetions of these omissions in regard to vertical distribution than I do in regard to horizontal distributions. with fev exceptions, the Intraneous assemblage is rather unfformly distributed over eastern Tennessee to an elevation around 2,500 


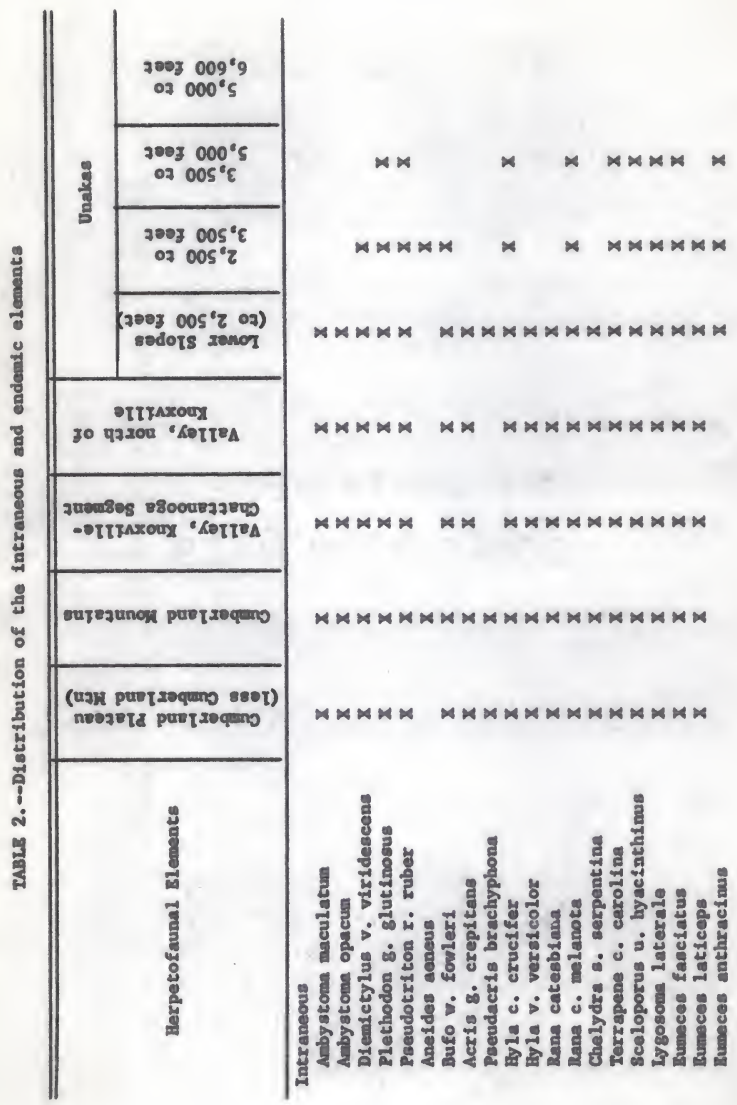




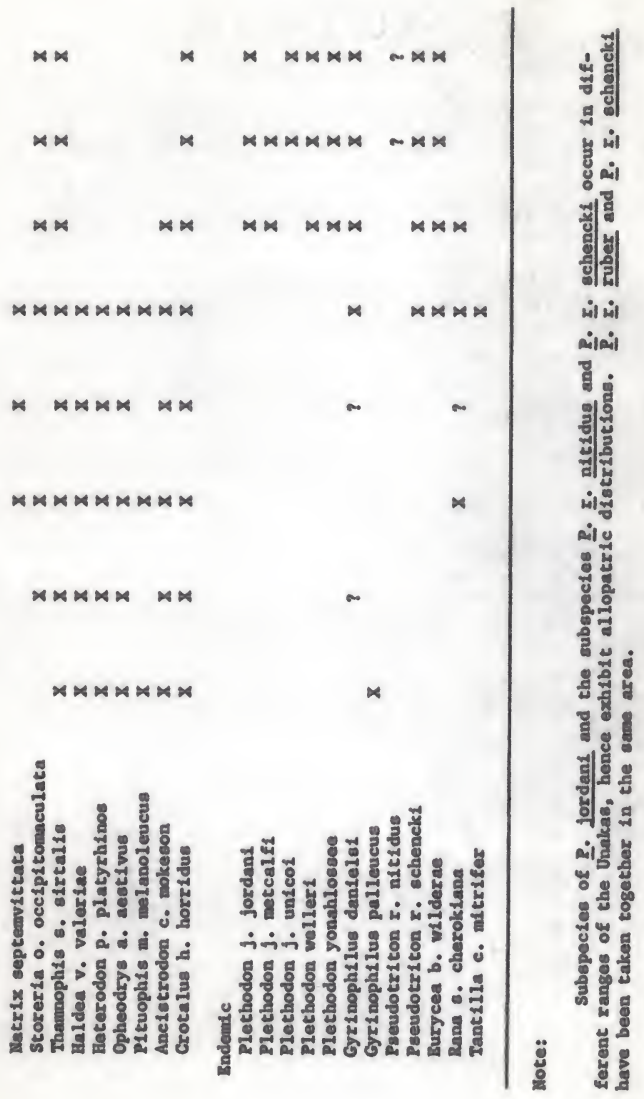


feet. Excopt for some of the peaks in the Cumberland Mountains and some of the outliers of the Unaka Hountains in the Valley, 2,500 feet is higher than the general level of the Cumberland Plateau and than the highest rldges in the Valley. The absence from the Valley of Aneldes and Pseudacris brachyphona 1s probably due to the lack of suitable hobitats. Cordon (1952: 698) reports the absence of locallties for Anoldes fron the Appalachian Valley and Implies that this salanander is restricted In distribution to the alxed nasophytic forest and/or mixed mesophytic forest assoclation segregates. According to Braun (1950: 232) there is some evidence of the presence of combunities elmilar to alxed mesophytic association segragates in the ravines of the northern segment of the Valley. It 18 possible that diligent search in this section may result In the finding of 1solated colonies, thus establishing 11nks between the colonies of the Cumberland Mountalns and the colonies of the Southern Appalechlan Mountalns. Peeudacris brachyphons seems to be restricted to areas where clear, shellow streans and/or woodland ponds furns ah ouitable braeding sites. I would anticipate 1solated colonies of this frog in the northern part of the Valley Province. It 1 highly possible that both of these forest-dwelling amphibians ranged across the Valley Province prior to the extensive deforestation resulting from the advent of white settlers. Question marks after the various forms 11sted in Table 2 indicate implied occurrence on the basis of published accounts. of the 28 Intraneous form Indicated as occurring on the lower slopes of the Unskas, 12 are not known to oceur in excess of 2,500 feet. 
Th1s is a lose of 43 per cent of the elements. Amphiblans account for 50 per cent of this lose. This 18 not too startling inasmuch as all these aphibiens are generally considered as inhabitants of lentic situations. Such labitats are practically nonexistent above 2,500 feet. The ebsence of the two aquatic turtles may be explained on the basis of the strean of this elevation being much too sulft, cold (?), and rocky. Iven the ubiquitous Chelydre would find footing difficult in these upperelevation streans. The sane factors mag be responsibla for the absence of Matrix septemplttata. The dropping out of Haldea $\mathrm{v}$. valeriae, Hete-

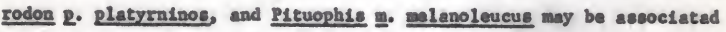
with the change in soll gpe. At the higher elevations the soll becones shallower and more asist, thus preseating an unfavorable fossoriel habltat for theee snakes.

A strlking difference between the assemblage of the lower slopes and that of the some between 2,500 and 3,500 feet 1 s the greater number of endeatc forms in the latter.

Between 3,500 and 5,000 feet there are 12 of the Intreneous elements reasining from the essemblage of the precading zone. The five forms which drop out are two salananders, one toad, one 11zard, end one snake. Lack of suitabla habitat may explein the ebsence of Dlendetylus and Aneldes, although for the latter there are many apparently suitable rock-crevice habltats. The explanation for the abeance of Bufo v. Loylert and Ancistrodon $\mathrm{c}$. mokeson is equally conjecturel. It 18 possible that at this elevation ufaimal temperatures my be too low or of too long duration, or that optimal temperatures axy be of too short duration, 
for embryonic development. Thls is suggested because the toad (B. $t$. americamus) and the snakes that do enter this and the suanit sones heve ranges which go farther north then those of B. $\underline{\text {. fowlert }}$ and $\mathbf{A}$. c. mokeson. The snakes Crotalus h. horridus, storerls o. ocelpitonaculats, and Thannophis s. Artalls are the only reptiles known by we to frequent the surmits in excess of 5,000 feet. Thls any be the result of these snakes being able "to follow the sun" and thus malntaln temperstures favorable for the developaent of embryos contalned in the bodies of the fenales. If thls assumption and the one concerning temperature and em-

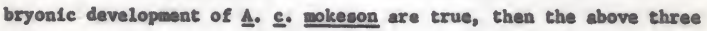
snakes may be more tolerant of lower teaperatures than $16 \mathrm{~A}$. $\mathrm{c}$. pokeeon. The same speculation applies to the two tosds.

In the ruandt rone, 5,000 to 6,000 feet, there is a depauperate herpetofauna. As mentioned above, only three snakes maintain thenselves at these levations. They are accompanled by the toad $\mathrm{B}$. $t$. americanus, designated as a northern extraneous form (Table 3), and certaln endenic plethodontid alamanders (Table 2).

of the endenste forms presented in Table 2, only G. pelleucus and G. danielst are found outslde the Unaks Province. G. palleucus 18 conflned to the Cumberland Plateeu Frovince. G. danlelsl contalns two subspec1es. G. d. daniels, apparently a lowland form, has a range extendIng from the Cumberland Mountains area esstward ecross the Valley to moderate elevations in the Dnake Province. G. d. dunni is Implied (B1shop, 1947: 362) as occurring from moderete to high elevations in the Onaka Province. If such is the case, then these two form are separated verticaliy. The remalning endemic forms are IImited to the Unaka Frovince. 
The oubspecies Pesudotriton I. nitidus and P. I. schencki are epparent1y separeted horizontally. According to B1shop (1947: 390), P. I. nitidue occuples the northern helf of the Unaka Province in eastern Tennessee and P. I. schencki occuples the southern half. It wovid eppear from Toble 2 that $\underline{\underline{P}} \underline{\underline{I}}$. ruber end $\underline{\underline{P}}$ I. schenclit are symatric. Th1s is discussed in the systemat1c presentetion of $\underline{\underline{P}}$. ruber. It mey be edded here that collection sites where $\underline{\text { P. }}$. r ruber keve been taken seen generelly to be drier than sites where $\underline{P}$. $\underline{\underline{r}}$ schencki have been taken. This suggests ecologicel separetion rether than altitudinal separation.

The subspeciee of Plethodon fordanl are, occording to the distribution maps of Highton (MS), horizontally saparated. P. 1. matcelfi 16 confined to that part of the Unake Province in extreme northeestern Tennessee. I. 1. Lordani is restricted to the Grest Smoky Mountelns, and P. 1. unleol 1s restricted to the high sumalts of the Unaka Mountalns south of the Little Tennessee River.

In sumary, it may be seld that there is a large intreneous herpetofeunal eseemblage which is quite uniformly distributed horizontelly over eastern Teanessec to en elevetion of about 2,500 feat. Apove this elevation the intreneous essemblage is divisible into three zonel sequences. The differentietion of these zones is besed, in part, upon the loss of constituent members from one zone to the next. The most ebrupt loss from the essemblage of the lower mountein slopes is amphblens charecteristic of lontic habitats. Such habitets are ebsent above this elevetion. In the 2,500 to 3,500 feet zone and the 3,500 to 5,000 
feet zone there 1s loss of a large number of Intraneous elenents and there is an increase in the relative number of endemic forms in the total assemblages. The loss of the intraneous forms is rather difficult to explain. It may be due to (1) lack of sultable habitats, (2) interspecific competition, and/or (3) adverse effects of temperature upon embryonic development at the higher elevetions. Above 5,000 feet the charecteristie herpetofauna consists of 73 per cent endenle selananders and 28 per cent Intraneous elements. All of the Intraneous elements are viviparous snakes. On the lower slopes are two forms of questionable validity which ore endenic to the Southern Appelachian Mountalns. One selamander and one turtle are endenic to the Cumberlend Plateau Province.

The extraneous herpetofaunel elements can be grouped Into three assemblages as the result of exanination of distributions presented in thls paper and examination of published diatribution mape. Comparison of Table 3 with Table 2 shows a remarkable similarity of distributional pattern between Intraneous end northern extreneous forms. There 1s, in generıl, a rather uniform horlzontel distribution of the extraneous elements over the Cumberland Pleteau (less the Cumberland Mountalns), the Rnoxville-Chattanoega Segment of the Valley (Fennemen, 1938: 271), and the lower slopes of the Unaka Provinee, north to about the latitude of the Franch Broad River. This applles to southern and western as well as northern extreneous forms. The Cumberland Mountains, the Valley north of Rnoxville, and the Unakas north of the French Broad River ore 11ke the other areas as regards northern extraneous elements. They are 


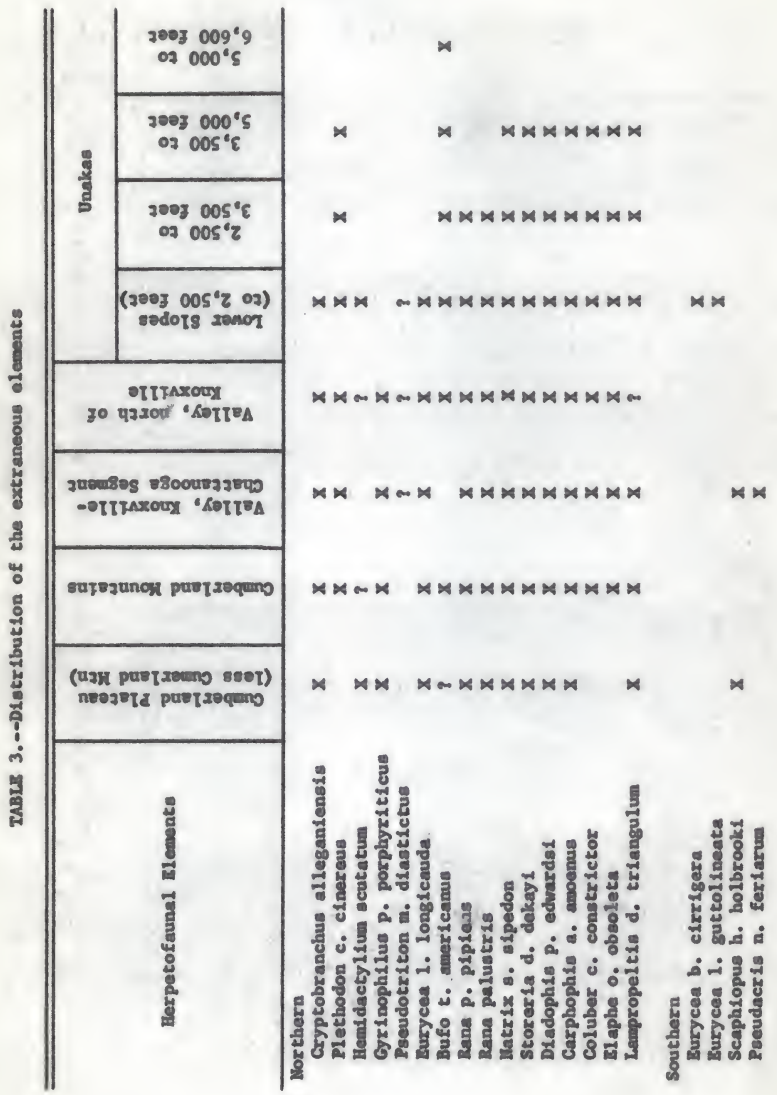


$x$
$x$
$x$

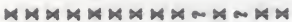

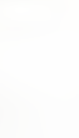

x

$\infty x \times x \times x \times$

$\times$

$x \times x a x x \times x \times x \times x \times$

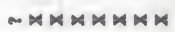

$x x$

$\times \times x$

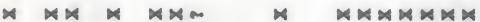

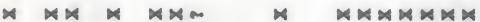

음

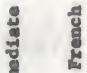

迹

ตै

음 분

8 .

ถู

$\rightarrow$

38
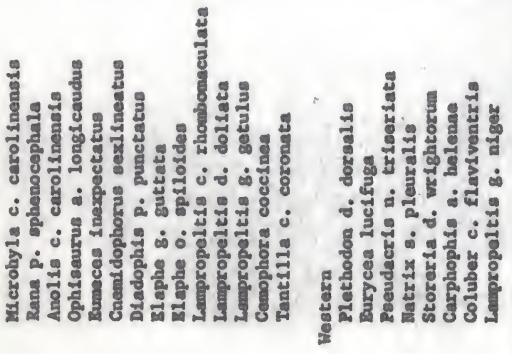
quite distinct In the apparent absence of southern and western extreneous elements. Thls is negative evidence on both counts and is subject to anendetion at any time.

What way seen peculiar is the large number of southern elements on the lower slopes of the Unaka Provinee (Table 3). Bven more peculiar 18 the indication of two southern forme escending as high as 3,500 to 5,000 feet on the mountains. In fact, one of these, Fumeces inexpeetatus, is apparently absent from the Velley Province. As mentioned In the account of Dladophls, m designation of numerous specimens of ringneck snakes as Intergredes (D1adophls R. punctatus $\times$ advardsL) is not accepted by Conant. But I think there is a very pleusible explanation for the occurrence of southern forms such as D. R. punctetus, in the mountaln province.

The mountain province is the wettest province in eastern Tennessee. At the base of the mountains the annuel precipitetion evarages 55 to 60 inches. The anmul rainfell Increases with eltitude to a maxdwum of around 70 inches par year at ebout the 5,000 feet level. The southern forme which escend to the higher elevetions are andmals oceurring in mesic or wat hebitets. The temperetures at high elevations ore not exceodingly severe. During a five year study of the weather of the Great Smoky Mountelns, the coldest month, November, did not everage less then $35^{\circ}$ F. et 5,000 feet (Shanks, 1954: 356). Further, Euryeas b. etrrlgers and I. 1. guttolineats, wh1le not occurring ot elevetions in excess of 2,000 feet, are confined to the lower slopes of the Unaka ProvInce. This, too, I think is expleined on the basis of precipitetion 
and temperature. Fach of these forme Is characteristically associated with or found in the vicinity of meste deciduous forest, or remants thereof. Braun (1950), In discussing the commanities of the Mred Masophytic Forest Region and the Oak-Chestnut Forest Region, repeatadly enphases the preposderance of southern plant apecies even at elevations In excess of 4,000 feet.

Specimens of Diedophis which in all reapects are "typical" D. R. edvardsi msy be taken In essociation with epecimens which are "typleal" D. R. punctatur eave for the high ventral-plus-gubcaudal count. This situation pertains only to the Unaka Province. I infer that D. R. edvardel is able to survive in habitats as molet as those in which D. $\mathrm{P}$. punctatus occurs. The paucity of spacimans fros the Valley and Cumberland Plateau provinces whlch may be designated as D. R. punctatus $x$ edvardes Intergrades is Inferred as Indicating that D. R. punctatus cannot survive in habitats as xeric as those inhabited by D. R. edvardal. The average annual precipitation in the Valley and on the Cumberland Plateau is around 50 inches. The average annual preclpitation in the Onaka Hountains range from 53 Inches along the western margin to 70 in. ches at high altitude stations where I have collected specimens considered as D. R. punctatua $\times$ edirards1 1 ntergradas.

In many of the distribution maps I have excmined, it seems that ranges of southern aphiblang and reptiles have been drawn to colncide on their northern boundarles with the physlographlcally delinited Southern Appalachian Hountains. Th1s I supposa is the rasult of the senerally accepted beliaf that mountains act as barriars to lowland organiams. As 
- result of this study, I belleve that the Southern Appalach1en Mountelns serve as effectively es a northward dispersel route for southern anphlblans and reptiles es they do as a southwerd dispersel route for northern forme. This hypothesis is substantieted by the equality of numbers of northern and southern forme on the lover slopes of the Unakas south of the French Broad River (Table 3). The occurrence of the southern form in the mountelns may be attributed to the moderate temperatures, even at higher elevations, and to the high sumper precipitation. These date permit a further speculetion. It is possible that southern forme are exhibleing postglecial expension of thatr ranges while northern forms are exhlbiting contrection of their ranges.

The occurrence of western forme on the lower slopes of the Unake Hountains may seen contredictory to the above conments, especially as the ennual precipitation of the Cumberland Plateau, where these western formo also oceur, 18 as mech as 15 inches less por year. Loeal cond1tlons of so11, slope, and exposure result in more rexic conditions on ridges and slopes with southern exposures. This is reflected in loeal differences in physical fectors such as insolation and temperature and In vegetetion (Braun, 1950: 205; Shanks, 1954, 1956; Whitteaker, 1956).

From the data presented in Table 3, I conclude that a line dravn at approxtmately the 2,500 foot level northward in the Unake Province to the French Broad River and thence northwestward to the Cumberland Mounteins would effectively separate two distinct herpetofeunal assemblages. Below this line the assemblages diverge because of admixture of southern, western, and northern extraneous elemente. As stated in the systematic 
accounts, this 11ne elso approximates the sone of intergredation between many of the conspecific forms occurring in eatern Tennessee (vide: accounts of Peouderys seripte, Natrix slpedon, Coluber constrictor, Elaphe obsoleta). The herpetofaunes of the Cumberland Mountelns and the Velley north of Knoxville are more libe thet for the 2,500- to 3,500-foot zone of the Unake Province than the herpetofaunas of the contiguous areas to the south. Braun (1950: 201, 214, 215, 232) Indicates vegetational similarity among the Cumberland Mountalns, the Valley north of Rnoxville, end the slopes of the Unakas between 2,500 and 3,500 feet.

In the Unaks Province above 2,500 feet, zonation 18 evldent anong the extraneous forms (Table 3). Bxplanation for this zonation would be similer to thet given in the discussion of the zonal distribution of Intraneous forms with similar hablts and habitat preferences. So far, only two turtles-oc. B. serpenting, T. E. carollng-have been presented from the standpoints of geographleal distribution and effinities (Table 2). Each of these turtles 18 constdered es an Intraneous form; the remsining turtles are considered es intranoous (1 form), extraneous (10 forms), or ondemic (1 form) (vide Table 1). These 12 turtles have been purposely onitted from the previous discussions. None of them is known to occur at elevetions in excess of 1,800 feet. Thus, whlle distribution maps may indicate these turtles oceur withla the confines of the Cumberland Plateau and Unake Mountains Provinces, they are ectually not "on the pleteau or the mountalns." For thls reason I do not consider them as part of the herpetofaunas of the Pleteau or the Unake Hountains. Further basis for this point of view is the 
ecologic reletionships of these turtles to comwunttles other than those of the najor rivers and streams.

Breept for C. P1cte, which way Inhabit stock ponds and other artificiel or naturel lentic habitats, these 12 turtles are confined to the larger rivers and streans. As a consequence, they, unlike the ub1quitous C. 2. serpentina and the terrestrisl T. C. caroling, do not es a rule directly effect the econouy of the communities of terrestriel habltets, small spring-fed branches, seepage arees, or texporary aquatic situations. For thls reason, I have not included these turtles in the herpetofaunal assemblages in Tables 2 and 3 or the discussions relating to these tables.

The 10 extraneous turtles are designated an western ( 4 forbs), southern ( 3 forms), and northern ( 3 forms) (Table 1). One of the northern forms, Graptengs geogrsphice, might with equal validity be consldered as a western form. The occurrence of so many extraneous forme 18 not difficult to understand when one considers the extent of the Tenneasee River Basin. Western forme could migrete up the Tennessee River fron ite confluence with the Ohlo River. Northern forms atght enter via the large headwater rivers in the Mdge and Velley north of eastern Tennessee (Johnson, 1954). Southern forms could enter the Tennessee RIver from tributaries in Alabams and vestern Tenneseee. One southern form, Pseudenys f. concinna, barely enters extreme southeastern Tennessee and perhaps should not even be consldered es a part of the turtle fauna. So far es evallable data Indlcete, P. E. concinne does not occur in the Tennessee RIver drainage. Data ere presented in the discussion on the 
specles I. floridana to Indicate that $\underline{\underline{P}}$. E. hlerosiyphice does enter Gulf Coast drainage (Conasauga River of southesetern Tennessee and northeastern Georg1a). It 18 probable thet the sone of intergradation between I. E. concinne and I. E. holroglyphice should be eltered to Include ell of eastern Tennessee (cf. Carr, 1952: 292).

For my eveluetion of the present distribution of aquatic organ18me In castern Tonnessee, a blologlcal survey of the Tennessee Rfver Besin made prior to the construction of dams by the Tennessee Valley Authority would heve been helpful. It is probable that the relsed weter level and controlled flow of the inajor rivers have resulted in the expanstion of the ranges of such forms as I. E. hetroslyphice R. $\mathbf{s}$. elegans, and G. R. quechitensls. Conversely, these same fectors may heve resulted in the extirpetion of some forme from the rivers below the dame.

These speculatione are supported by date from a study by Dendy and Stroud (1949). They report thet the Little Tennessee River below Fontana Dam hes been ehanged from e varm-weter river to e coldwater river. Calderwood Reservolr in August, 1938, had e sur face temperature of $85^{\circ} \mathrm{F}$. and a temperature at a dapth of 20 feet of $800 \mathrm{~F}$. While in August, 1949, these same levels had teaperatures of $70^{\circ} \mathrm{F}$. and $56.25^{\circ}$ P., reapectively. Calderwood Reservolr formerly supported bass oucropterus dolonilev) and walleye (Stizostedion vitraum). These f1sh are now ebsent, and present temperature conditions suggest thet relnbow trout (Salmo galrdner11) and brook trout (Salvelinus fontinalis gont1nal1s) may be able to ourvive there. Such drastie changes wast have some effect on distribution of the herpetofaun inhabiting these waters. 


\section{B. Envlronmentel Pectors and the Herpetofauna}

Van Steenis (cited by Cain, 1944: 155) Indicates three handicaps faced by the plant geographer In his appraleal of the past and present processes 1nflueacing the aree occupled by plents. These are: "(1) the usual absence of any exact date regarding the age of species; (2) the ususl absence of any proof regarding dispersal . . i (3) an uncertainty whether an axea 18 expanding or retracting." These same handicaps confront the animal geographer. Caln goes on to say that "any eriticel coordinstioa between geographical date and paleoecology, geology, or paleoclinatology must be regardad as a piece of luck."

The attempt to discover causal relations, or even correlations, among the various herpetofaunal assemblages and sats of environnental factors is baffling. This is not entirely the result of the three handicaps mentioned above. Another serlous limstation to an adequate interpretation is the lack of knowledge of the ecological requirements of the animals Involved, and, where such knowledge may be avdilable, the lack of Information es to which processes of the 11fe cycle are critlcally affected by the interaction of these factors. I have speculated at several points in the discussion of the various herpetofaunal assemblages as to why certa1n forms may be absent from adjecent assemblages. Assuming conjectural eppreisels to be correct, they by no meane give a complete explanation of the presence of the form in question in its assemblage. The most that can be hoped for is that such speculation, and that which appears below, any suggest factors that interect to influence the diatribution of the essemblages. 
I an unable to detect any positive correletion among the various asemblages and the macrocliaticie date from stations in their respective areas. However, speculation regarding the influence of certein climatic factors is possible. The greater number of southern forms on the lover slopes of the Unaka Mountalns south of the French Broed River, as compared to contiguous arese to the north and to the west, may be attributed to the high sumer precipteation in this area. The collective diatributions of the southern and vestern forms suggest colnefdence whth (1) the 1sochronous IInes of Apr11 10 to 15 for the average dates of the letest killing frosts in the apring ("Yearbook of Agrieulture," 1941: 1125) and/or (2) the 50 Inch annual precipitation 1sohyet [In part] es shown on the map Tennessee River Basin Mean Annuel Precipltation published by the Tennessee Valley Authority. If elther or both of these lest two possibilities are real rether than more colncidence, then they prevell only in limfting the northern and eastorn parts of the ranges of the southern and western forms respectively. Just how this limitation would be affected I do not know. I would speculate that the influence is exarted upon the roproductive processes. The absence of the southern and weatern forms from the Unake Hountalns north of the French Broed River, the northera part of the Valley, end the Cumberland Mountains may be the reault of decressed precipitation and/or later ave crage dates of letest killing frosts in the spring.

As regards the limits of horizontel and verticel distribution of the northern extraneous forms and the vertical distribution of the intraneous forme, I do wot think climate is an importent limiting factor. 
A possible exception to th1s statement is discussed on pages 171-172. The northern extraneous and the Intrenoous forms range farther north whare temperatures and precipitation are less than in eastern Teanessec. Conversely, tha intraneous forms range farther wouth where at least the temperatures are greater. Many of the northarn, eouthern, and western extraneous forms are subspecies of the same species. Consequently, the factors, other than climate, 1initing their dietributions may be those responsible for allopatry of eubspecies.

Sone of the high-altitude endenale salamanders have abrupt lower Iimits of distribution (Highton, personal communieation). I do not consider present elimatic conditions as a significant factor in lindting the descent of these forms. If such were the case, I would expect them to be confined to particular foreat complexes such as the spruce-fir forests. This forest is colneldent in distribution with a distinctive type of clinate as detarmined by Shanks (954). To knowledge, tha only endemic salanander that is apparently restricted to particular forest associtiation 1s R. 1. unleo1. The forest association at the type locallty is northern hardwoods.

Attention hes been drawn to the colneident diatribution of certain couthern extraneous forms and the vegetational couplexes characterlaed by a large number of southarn plant specles. Similarly, there is unfforalty in the herpetofaunse of the Cumberland Mountalne, the northern part of the Valley, and the slopes of moderate elevation $(2,500$ to 3,500feet) of the Unakas and uniforasty of the forest associations of these areas. Additional 1llustration's of parallel situations between 
d1stributions of herpetofauna and vegatation are available. These apply to the saparation of the assemblages into vertical groups. Whittaker (1956: 38) statas that in the Great 8moky Mountalne the "relative Importance" of oak and pine stands in the climax forest pattern decreases with an inerease in elevation, while the inportance of nesophytic stands Inereases with atnineresse in altitude. These changes are evident at 1ntarvals of about 1,000 faet. Oak and pine stands are wost prevelent between 2,500 and 3,500 faet. Mesophytic stands become incraasingly pravalent from 3,500 to 4,500 feet. Above 4,500 faet, the surmits are clothed in fir and spruce-fir foreats. The decrease in number of northern extreneous and number of Intraneous herpetofaunal elements with an Increase in altituda parallels the situation of the oak and pine stands. The Incrass in muber of endenic forms of salmanders with an inerease in altitude parallet the altuation obtaining with aesophytic atands.

These coincidences between herpetofaunal assemblages and vegatational associations do not explain why the assemblages exist where they do. It meraly suggasts that perhaps the aave comblantion of factors may control the distribution of amphiblans and reptilas, since all In a sense are endothermlc organtans.

There is no correlation between the diatribution of the various assemblages and the major sofl types of eastern Tennessec. This is not to be construad as indieating that soil is of no importanca to the distribution of amphiblans and raptiles. Such soll factors as depth, textura, and nolsture-retaining capacity undoubtadiy influence the loeal distribution of fossorial forms. 
Men 1s one of the most important environmental factors operatIng to influence the distribution of the herpetofeunal elements. Onfortunately, there are few data upon which to base an assessment of the effect of iman's activities. Aside from direct extirpation, the greatest effects upon the distribution of the varlous assemblages would be that of causing the expansion of ranges of nonforest forms and the contraction of ranges of forest forms. The primary cause of these simultaneous expensions and contractions was, and 1s, deforestation conseguent upon lumbering and clearing for agricultural activities. Ayres and Ashe (In Museage fron the President....," 1902: 45) report that in 1900 only 73 per cent of the Southern Appalachlanswas forest and of th1s only 7.4 per cent $[5$ per cent of the total $]$ was primeval forest. This does not Include the Cumberland Plateau nor the Valley, which, being wore accessible, must have experienced even more extensive deforestation.

The effect of the Impoundment of rivers by the Tennessee Valley Authority has been discussed previously (page 182).

To the discussion of the colncidence of the distribution of the herpetofaunal essemblages with climate and vegetation should be added an appreisel of the element of time. It is lmportant to ask whether the various herpetofaunel esseablages are in equilibrium with their reopective habitats or whether they are still undergoing postglaclal readjustment. Braun (1950: $500 \mathrm{f}, \mathrm{f}$ 1951) states that the present pattern of deciduous forest distribution has changed 11ttle since the close of the Tertiary Perlod. Her supposition is based in part upon the occurrence of mixed mesophytic forest essociations in the Great Smoky Mountaing 
d1sfunct from the center of greatest development of mired mesophytic forest in the Cumberland Mountalns. Further, the occurrence of endente spectas of plants in the Southern Appalachian Mountalns is acceptad as evidence that Pleistocene avents did not serlously affect the vegetation of the Gumberland Plateau and Southern Appalachien Mountains. If the corralation between the distribution of the various vegetation coaplexes and the herpetofaunal assamblages is real, then the reasoning of Braun would apply to these assemblagas. That 18, the distributions of the varlous herpetofaunal asseablages are now essentially as they were at the close of the Tertiary, with minor fluctuation In Pleletocane time. To intarprat the history of the distribution of tha various herpetofaunel groups, the dietribution of the intraneous alements is of neg11gible valua. They would only indicate verticel movements. The effects of Plelstocene avents upon vertical as well as horizontal movements of the assemblages might better be Interpretad from the distributions of the extraneous and endenic forms.

A knowledga of the Plalstocene fossil herpetofaune of eastern Tennessee would of course be extremaly helpful in this laterpretation. The presence of fossil forms aquivalent to those occurring in the area today would not be prima facie evidence that auch forms have always axLeted In this araa. But, it would Indicate that they have at least returned to an aree formerly 1nhabited. That somevertical shifting occurrad during Plelstocene glaclation may be lnferred from the erldence oug* gesting a timberline alavation of betwean 4,000 and 5,000 feat in the Great Saoky Mountalns (King and Stupka, 1950). Latitudinal ohifting of 
herpetofaunal eleante may be Infexred from the work of Auffenberg (RS). Ile reports the findings of fossil (Pleistocene) Carphophis amoenus, Buneces fasciatus, and Preudamgs seripta in peninsular Florida. These forns are not present in peninsular Florida today.

The pecullar distribution of the turtle Peauderys s. troosti may perhaps be explained as the reeult of mextmun Pleistocene gleciet1on. This turtle is considered endemic to the Cumberlend Plateau area. Exanination of its range (Carr, 1952: 241) shows that it is bounded on the north, west, and south by I. S. elegans. Part of th1s extensive diatribution of $\underline{\underline{g}}$. ‥ elegens may be attributable to recent range expansion (vide page 72). R. s. troostl does not now 1nhabit waters wh1ch would have received melt-nater from the glecier in southern IIIInols, Indiana, and Oh10. Suppose a troosti-11ke ancestral form Inhabited, prior to maximum glaciation, all of the area now occupied by $\underline{\mathbf{P}} \mathbf{\mathrm { s }}$. elegans and ‥ s. troost1. During meximum glaciation, the ancestral form would have been driven fron ite range in southern Illinois, Indiana, and Ohlo and some of the area west of the Mississippl River. Because of the cold melt-water flowing down the Ohlo and Mississipp1 rivars, the ancestral form would have been forced to retreat southward, but some population could have survived in rivers not receiving meltwater. That population in the Cunber land Rfver dralnage would have bean effectivaly 1solated from populatione farther south along the MississipPi Basin, and even In the Tennessee River Basin, by the cold water of the Mississippl and Ohio rivers. During this 1solation, genetic differences could have arisen soparating the 1solated population in the cumberland drainage and the populations farther south. That the Cumberland 
population should have survived so near the glacial border is not a prob1ex. Thomes (1951) discusses animal distributions in gleclated Oh10 which are most plaustbly explatned on the basis of refugia in the Cumberland Ilateau south of the lce margin. Sintlarly locatad refugla for plante are discussed by Braun (1951) and Wolfe (1951). That ‥ ‥ troost1 is now confined to such a narrow range way be due to swamping out of troost characters in the lower portione of the Cumberland dralnage by the return of the perhaps more vigorous …․․ elegane. ‥ ‥ troost1 is thus an eptbiotic form (Ridley, 1925).

Possible Influence of the postglactal zerothermic period upon the harpetofauns of eastern Tennessee lo suggested by the distribution, or occurrance per Be, of the western extraneous forms.

During the xerothermic perlod the weatern extraneous forms may have entered eastern Tennessee via the Cumberland Plateau and crossed the Valley to the lower slopes of the Unaka Mountelns. Natural prairie post oak openinge are at present on the Cumberland Plateau as rellc: cowmunteles (Shanics, personal cownunlcation). Braun (1950: 121, 155) dL8cusses preirie commuties in the Knobs Area of the Cumberland Plateau in Rentucky OHred Mesophyt1c Poreat Region) and In the Western Hesophytlc Forest Region of the MIghland Rim area of Tennessee and Kantucky. If prairie conditions existed on the surfaca of the Plateau, 1,000 feet above the Vallay, they must have occurred in the Valley and on the lower Llopes of the Unaka Mountains. Whittaker (1956: 60) assumes the ascent of vegatational sones In the Graat Smoky Mountains a a result of the rerotheralc period to account for the presant distribution of the 
spruce-f1r forests of that region. According to his hypothesis, this ascent wust heve been in the neighborhood of 2,000 feet. The occurrence of veatern herpetofaunal elements on the slopes of the Onakas is at present 500 to 1,000 feet above the general level of the Valley floor. The Cumberland Mountaine and the Valley north of Knoxv11le apparently do not heve these western extransous forms among thelr respective herpetofauna assciblages. Thet these western forms may hove ranged higher on the mountalnc and farther northward in the Valley 18 probable. Following the close of the xerothermlc period, the weatern elements may have descended the mountains and retreated southward in the Valley.

Possible modes of formation of the endenic subspecies asy be 11lustrated by discussing two groupe of subspecies of salanandars. One mode of subspeciation has already been discussed in connection with the distribution of the turtle $\underline{P}$. ․․ troost1. Further, this seews e propitlous plece to comment on the ages of the subspecles. I do not believe the subspecies discussed below, nor most of then for that aster, can be older than 1,000,000 years and are probably wuch younger. Deevey (1949: 1320-1321) expresses a similar op1n1on. Auffenbers (US: 249) states that modern opecies of amphiblans and rept1les became extablished In carly Ple1stocene t1me. Zauner (1950: 373) presents data indicating that subspecific differentiation may occur in 5,000 to 7,500 years and states (loc. c1t.: 382) that a species does not remaln unaltered for wore than 500,000 to $1,000,000$ years.

Differentiation of the aubapecies of Plethodon Lordant as defined by Highton (OS) may be explained as the result of the effects of 
the postglacial zerothernic period. Assume that an ancestral population was widespread throughout the Southern Appalachien Mountains prior to the advent of the rexothermle perlod, and, that there was a free exchange of genes in all directions except in the populations occurring at the higher elevations of the various mountaln ranges; $\mathrm{e}$. $\mathrm{g} .$, the Unakas north of the French Broad IIver, the Great Smolk1es, and the Unakas south of the Little Tennessee River. These populetions would hive experienced gene exchange only with contiguous populations on the lower slopes of their respective ranges. During this period of partial 1so. lation of the high-elevation populations, winor genetic differences could heve developed in response to vertical gradients of environmental factors. With unfavorable environaental differences in the lowlands as a result of the xerothernlc climate, the lowland population would have been exterminated. The lowland segment of the ancestral population could not ascend the wountains because sultable habitats vere already occupled. With the disappearance of the lowland population, the populations of the higher elevations becane effectively isolated from each other. During this tine of 1solation, these populatione became differentiated Into the presently recogntred subspecies of $\mathrm{P}$. Lordant.

Presumably, Clemson's salamander, Plethodon L. clemsons (Brim. ley), 1s the only lowland form. It asy represent a remant of the ancestral population which found refuge in gorge habitats during the rerotharnic period.

Halraton and Pope (1948: 277) and Mghton (op. c1t.: 113-114) propose river entrenchnent the factor responsible for isolation of 
populations differentlating Into the subspecies of P. Lordanl. I preaune Highton baees his acceptance of this hypothesis upon his fallure to find intergradation anong the subspecies in the major river valleys, whlch he states are presently ecologically unsuitable for oceupency. He does flnd Intergradation among some of the subspecies on the mountains. This latter condition is not incoupatible with the zerothermic hypothesis outlined above. Rather, it would be an anticlpated situation. Aaelioration of climate following the ternination of the xerothernate period would heve perwitted the 1solated populations to deecend the mountains, with consequent expansion of their respective ranges. Wherever expanded ranges of adjacent populations cone iato contact, intergradation could occur. Absence of some of the subspectes from the major river valleys may be explained as the recult of insufficieat tine to heve reached the valleys, in addition to, or instead of, their being ecologlcally unfavorable.

I do not subseribe to the river entrenchment hypothess for two reasons. First, the higheat river terraces of Plelstocene age in eastern Tennessee are only 400 feet above the present rtrer valleys frodgers, 1953: 129). I speculate that such entrenchment would have progressed so slowly that the ealemender populations would have been able to become adjusted to any resultant chenges in hebltat. Second, as indicated previously in this paper, changes in zonal distribution of herpetofaunsl assemblages and vegetation involve differences in elevation in the netghborhood of exound 1,000 feet, not 400 feet. Moreover, the zonation in these associations is not evident below an elevation of 
2,500 feet. The terraces of which Rodgers opeaks do not exceed an elevetion of about 1,500 feet.

D1stribution of the subapecies of Pseudotriton ruber presents, to ate at least, e more complicated situation than 1 s the case with the P. Lordant subspecles discussed above. The endemic subspecies $\underline{P}$. $\underline{\text {. }}$ nItEldus and I. I. schenckI are completely surxounded by the subspecles R. I. ruber. Wy data Indicate the further possibility that the ranges

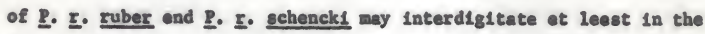
Unakas south of the Little Tennesses River. Or, this may be an area of Intergradation. If the first possibility 18 correct, then this must be a case of ecologic (microgeograph1c?) 1solation. I shall not pursue this further because of $m$ Inadequate knowledge of the ecologic requirements of the various subspecies.

For purposes of th1s d1scussion, I shell essume that both $\underline{\underline{P}}$. $\underline{\text {. }}$ nit1dus and I. E. schenck1 are 1nhabitents of the higher elevations and that I. I. ruber 1 a lowland form capable of ascending to high elevations whare conditions are sultable. Further, I should amphasise that I ain not fandilar with $\underline{\text {. }}$ r. n1t1dus. I presume fron deseriptions and pictures that I. I. 足tidus and I. I. schenck1 are more closely related

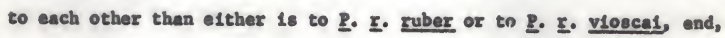
that the last two are more closely related than elther 1 s to the first two.

The distribution of the subspecies of $\mathrm{Z}$. ruber (B1shop, 1947: 390) suggests at least two interpretations. One of these Involves an unfevorable climatic condition during the xerotherable period similex to 
the discussion concerning the subspecies of $\underline{\mathbf{R}}$. Lordant. With the advent of the rerothermic period, conditions became favorable for vestern biota. Th1s vestern blota may have extended notonly as far east as the lower slopes of the Southern Appalach1an Mountalns, but as far south as the "black belt" of Alabana. The presence of thls vestern blota had a fourfold affect upon P. ruber (the ancestral population of the preseatly recognized subspeciee). One population was isolated in the Gulf coastal plain and differentiated into P. $\mathbf{x}$. vioscal. Another population was displaced to the north and different1ated Into R. I. ruber. Two other groups were displeced vertically Into, or 1solated In sites In, the Southern Appalachian Kounta1ns. These two groups differentiated into P. I. N1tldus north of the valley of the French Broad River and $\underline{\mathbf{P}}$. $\underline{\mathbf{I}}$. echencll south of the French Broad IIver. Xerothermlc conditions prevalling In the wide and low valley of the French Broad effectively 100lated these two mountaln populations. With the vaning of the xerotheralc perlod and the return of more favorable conditions, each of the reaultant subspecles began expansion of range. For some reason, ‥ . ruber mast possess an advantage enabling it to have expanded its range, vertically as well as horizontally, more rapldly than any of the other three.

A second possible interpretation of the distribution of these subspecles Involves a taxonomle rather than a blologieal Interpretation. The speculation 18 that the subspecies represent terainal populations of a species exhlbiting clinal variations. Lowland forms, B. I. ruber and P. I. Vlosea1, may obtain some adaptive advantage from possession 
of a greater amount of pigmentation than the lighter forms occuring at high elevations. Thus, $\underline{\underline{P}}$. $\underline{\text {. }}$ vloseal would represent a terminal population exhibiting baximum expression of pigmentation. ‥ ․ nftidus and $\underline{P}$. I. schenclet are vert1cally distributed populations exh1biting maximum expression of a different adaptive character--reduction of pigmentation. As each of these last two forms Inhabits a different mountain range with different comblnations of environmental factors, the wanner of expression of the cheracter differs between the two populat1ons. This speculation is capable of belng tested by Intensive ecologic and taxononic study of the species.

It Is appropriate to conclude thls section with a brief appra1sal as to the relative importance of ecologlc factors veraus historic events as determinants of the distribution of the ierpetofauna. In the discussion, ecologic factors refers to the enviromental conditions existing now, including the affects of the activities of an; historic events refers to those hanges sssoclated with natural phenomens involvIng extensive periods of time.

The two categories of phenomana, ecologic factors and historic events, while interrelated, may be considered separately. The ecologic factors are responsible for the local distribution of the different aphiblans and reptiles within their respective areas. The extraneous forms, because they are near the perlphery of their ranges, and the endentc forms, because they occupy restrleted areas, are apt to be more drastically affected by changes in ecologic conditions than the intraneous forms. Historic events, hovever, are responsible for distribution 
patterns evident among the varlous herpetofaunal assemblages. The historle event interpreted as belng of greatest significance relative to the distributional pattern is the rerothermic perlod. The effects of this period are discussed above in relation to the vestern extraneous forms and certain of tha salamander subspecies. As with changes of ecologic factors, historic events are apt to have had wore influence upon extraneous and endente assemblages than Intraneous assemblages. Th1s situation way be attributable to greater vag111ty of intraneous organ1sma.

\section{Blogeography}

In a paper (unpublished) presented before the Amerlean Soclety of Ichthyologists and Ilerpetologists I discused the quest1on, "Where do the Mountalns Begln?" This resulted from ey collecting "In the mountalns" amphiblans and reptiles no different, or 1Lttle different, from those occurring in the Valley.

It is widely known thet eountain blota of higher altitudes is distinct frow lowland blota (Hesse, et 스.. 1949: 588). The data presented In th1s paper and by others (Braun, 1950; Shanks, 1954; Wh1ttaker, 1956) Indicate thet on the vestern slopes of the Southern Appalachian Mountalns below 2,500 feet, the inds of communities encountered are little if any different from those occurring in the Valley Province. Except In localized sltuations, blotic distinetness between Valley and Unake provinces 1 s not noticeable unt1l an elevation of 2,500 to 3,000 feet is attained. 
As implled earller, the practice of defining ranges of auphiblans and reptiles in terms of physlographle province boundaries may result in error. If the periphery of the range of a lowland form 18 shown as colneident with a wountainous physlographic unit, the Implieation is that distinet mountalnous ecological factors (Hesse, a 스., op. c1t.) are operating at or near the edge of the area. The data presented In this paper, and the references eited, show that where the mountain front is not precipitous, this may not be the case. Since, to the b1ologist, the term mountain has specific ecologic connotations, care should be exercised in the use of thls term for defining ranges of organismb. There should be some Indication of how high or how low ion the mountaln the organism or comanity oceurs.

The concept that the spruce-fir foreats of the high oumats of the Southera Appelachian Mountains represent relict comeunities of boreal forest 18 suspect. This 1 dea wast be besed upon the assumption that during Plelatocene glaclation there was continuous boreal forest along the higher portions of the Appalachlans. Following the retreat of the glacier, spruce-fir forests survived only on the highest sumits of the Appalachian ranges. I believe that most blogeographers subseribIng to this concept are influenced primarily by the physlognonic simflarity between these Appalachian spruce-fir forest connunities and those of boresl regions. The evidence 1s against genetic unity of these separate associations, hence, they are not identical biotic units.

Shanks (1954: 360) presents data Indicating that the "taiga epruce-fir forests are, In general, both wuch colder and drier than the 
spruce-fir of the Southern Appelechlan Mountelns." The cool superhumid climate of the Southera Appalechien sumalts is epproached near sea level only In northern New Bngland, the adjecent Maritime Provinces of Canada, and coastel arees of Washington and Oregon. Braun (1950: Map of Forest Reglons and sections) does not Include New Bngland and the Maritime Provinces In the boreal spruce-fir forest. Further, the opruce (Pices zubens) and the fir (Ables freseri) are considered so endente to the Southern Appalach1ans (Breun, 1950: 209, Whittaker, 1956: 53). The charecteristic shrub opecies of the opruce-fix forest are primarily Appalachian and Pledmont in distribution. That none of the herpetofeunsl elemente occurring in the Appelechlen spruce-fix sone is found In the boreal spruce-fir forest supports the 1dee of the distinctness of these two forests. The deelgnation of the Appelechian opruce-fir forest ds Canadian or boreal is in moplnion incorrect and obscures Its singularity.

The ebove remarks lead to e consideration of the systems of clessificetion of the blota of Morth Anerice. I shall not attampt to revlew eech of these systeans. Kendelgh (1954) presents a history of and an eveluation of these concepte for Morth Americe. Hy own renarks will be concerned with certaln of the exiteris utilised by varlous authors in establishing blotic subdivislons.

Most of the ettempts to divide North Anerica Into bioticelly distinct areas purportedly lnvolve an analysis of solis, clingtes, floras, and founss. Frequently, however, only one or two of these groups of factors are ut1lized, or et least are given primary emphesis, in 
characterizing the areas. Although Merriem (1892) besed his 11fe zones primar1ly upon temperature, he quotes and endorses (loc. c1t.: 397) a statement of Ase Gray: "'Plents," sajs Dr. Gray, 'are the tharmometers of the ages, by which elimatic extremes and climate in general are best measured.'" Clements and shelford (1939: 229-230) state that the best expression of land elinates is the climax comunity with 1ts character1stic ilfe form. The ilfe forms of most land comounities are dotormined by the doninant plants. Dice (1943: 5) places great emphasis upon plant communities for defining h1s blotie provinces, distriets, and belts because "the plants often Indleate the characters of climate and so11 upon whlch animals are dependent." According to Caln (1944: 14), the primery cause of vegetation is climate, with edaphic control secondaxy.

I belleve that associations of anphibiens and reptiles, or other kinds of poikilotheraic animals, could be used as effectively as vegetation for Interpreting affects of past and present climates upon b1ot1c associations. To do this would require mech more information of the ecologic requirements of these animals than is now avallable. However, data has been accumulated to Indicate that physlological activities of "cold-blooded" animals are directly influenced by such factors as $\mathrm{pH}$, molsture, and termperature of the atmosphere and eubstrate (Allee, eㅡ 스., 1949; Hesse, et al., 1949). Mmong amphiblans and reptiles, this is especisliy true of the reproductive procesese. Conversely, the homolothernic b1rds and mamals are lass oubject to the direct influence of these same factors. Thus, It seems Incongruous to me that b1rds and 
manals should be given a status equal to plants in the defining of blotic reglons. Rather, I think that poikilothermic animals should be key forns equal or secondary in importance to plants for defining b1otically distinct regions. Perhaps permanently aquatic animals axe best excluded because their habitats are generally less variable than terrestrial ones. Further, dispersal of permanently aquatic forms-. excluding those with vind-born stages in the life cycle--is dependent upon contiguity of habitat.

Merrian (1892: 415) eaploys manals to 11lustrate his iffe zones because "they answer the purpose better than any other single group." I question this for reasons given above. Allen (1892) considers mamals as key organisms because (1) their diopersal is lese dependent upon fortuitous circunstances, (2) they are less dependent upon other groups of enimels, (3) because of their "power of edaptation" they are able to exist over the whole globe, (4) their distribution and dispersel are dependent upon land axeas and are modified by barriers such as mountains, forests, grassy or desert plateaus, (5) their geological history is better known, and (6) there is greater unandmity on their taxonomic affinities. It seens to that each of these reasons, with the possible exception of numbers 5 and 6 , could as well be clted to justify using amphiblans and reptiles as key organiame for defining faunal reglons. Admittedly our knovledge of reptiles and amphibians has Increased greatly olnce the time of Merrian and Allen. But, I think they falled to understand the importance of the more direct relationship between the physiological activities of "cold-blooded" animals and the physical environment. 
Rhoeds (1895: 381-382) discussas the herpetofaune of Tenneasae In terms of Allen's faunal reglons. Accordingly, eastern Tennessee beLow an elevation of 3,000 feet is Included in the Carolinian Fauna, characterized by the following: opossun, Didelphye marsuplalls; pine mouse, Mcrotue plnetorum; least mole shrew, Mlarina; typical forms of the eastern deer mouse, gray squirrel, wood rabbit, gray fox; deadian flycatcher, Zmpldonax acadicus; yellow-breasted chat, Icteria virens; Rentucky warbler, Helminthophlle plnus; Bewleke's wren, Phryothorus berlek11; pine-tree 11zard, Sceloporue undalatus; nebulous toad, Engystoma carolinense; pilot snake, Coluber obsolatus; box tottolse, Terrepene carolina. (A11 inames appearing in thls and following 11sts are those employed by Rhoads.) Between elevations of 3,000 and 5,000 feet in both the Cumberland and Unaka mountalns is the Alleghanian Fauna, characterised by the followlag: red squirrel, Sclurus hudsonfus; wole shrew, Mlarias talpoldes; brown shrew, Sorex personatus; Canadian warb1er, Sylvania canadensis; least flycatcher, Bappidonex minimus; W11son's thrush, Turdus fuscescens; dusky selanandex, Amblyztome Leffersonianum; black salamader, Desmognathus nigra; northern opring frog, Rana clemitans melanota. In the epruce-fix zone above 5,000 feet 1s the Canadian Fauna, characterized by the following: mountain deer mouse, Peromseus; great red-backed wole, Bvotomys carolinensis; bog vole, Synaptomg; winter wren, Troglodytes hlemalle; golden-crownad kinglet, legulue satrapa; common crossbill, Loxia c. minor. Though perhaps more clearly defined, these fauns are essentially the same in distribution as the 11fe zones ascribed to th1s area by Merrien (1892). Merrian's equivalents of 
Allen's feunss are as follows: Hunid Upper Austrel zone : Carolinian Tauna; Bumld Austrel Transition Zone . Alleghenlan Fauna; Canadian zone . Canadian Tauna.

I consider these faunistic subdivisions of eastern Tennassee as Inadeguate. The Inappropriateness of designating the high-ounalt arees as Canadian has elready been discussed. In comparing Rhoad's lists of blrds of the various faunas with those of Ganler (1933), a doubt 1s cast upon the efficacy of these birds as Indicator organiens. In the f1rst plece, none of the birds 11sted by Rhoeds is a permanent resident of eastern Tennessee. Noreover, the Canadian warbler, least flycatcher, W1Ison's thrush, winter wren, and golden-crowned klnglet are "rare" hlgh altitude sumer residents. Also, the other blrds are aerely comnon summor rasidents. It seeme to me that if an animal is to be thought of as charecter1sing a particular blotic reglon, it should be a parmanant resident of the area in question.

The signiflcance of the manmals 11stad as zone Indicators $1 \mathrm{~s}$ equally suspect. The opossun, for 1nstance, has such a vide geogrephlcal distribution that the inclusion of it as a diagnostic apecies for limited biotic unit is velueless. Other mannals are listed acrely by generic name, hence eveluation of their signifleance is not possible. Finally, thare are two species of rebbits Inhabiting eastern Tennessee (Hanliton, 1943: 383, 388) and two subspecies of gray squirrels (10c. c1t.: 228). It is not known to which rabb1t and to which squirrel Rhoads referred.

In defining biotic units In a limited area, especially an ara with es varied habitat conditions as eastern Tennesee, the distribution 
of subspecies seems all-important. Deevey (1949: 1318) also expresses the opinion that distributions of Infraspecific categories may be more helpful in biogeographic studies than distributions of species and species groups. tion as a blogeographic eriterion is founded upon m concept of the subspecies. I subseribe to the belief that genetically controlled mor* phological and/or physiological differences between subspecies, developed during 1solation of ancestral populations, are basically adaptive. The inadequacy of the amphibian and reptile species eited by Rhoads is apparent from the systematic treatmont of the same species as presented in this paper.

It is known that in some cases animals are sssociated more closely with particulax ilfe forms of vegetation than with particular kinds of plants (Rondeigh, 1954: 166). Nevertheless, if the communities of different kinds of plants of the same life form are found in different portions of a given region, then local habitat differences may be indicated. Likewise, the different combinations of species and subspecles of animals within a given region may Indicate habitat differences even though the life form of the dominant plants in each of the associatione 1s the same. This latter supposition is valid only if there are no physlographic barriers to the dispersal of the animals under consideration, and only if there has been sufficlent time for them to heve occupled all of the avallable habitats in the area. Usually, it is difficult to deternine whether there hes been sufficlent time for the varlous animals to have oceupled all available hebitats. Conversely, unifornity of life 
form of the climax commulties of a region may be itdicative of uniformity in mafor climatic features of the region.

Insofar as practicable, nomenclatorial recognition of ecological assemblages of organisms (In confornity with the biba concept) should Indieate seral relationships. However, determination of the seral position of such asemblages is frequently difficult. In the present case the status of knowledge of the elcologlcal requirements of the reptiles and auphiblans of eastern Tennessee does not permit me to evaluate the seral relatLonshlps of these aninals. Accordingly, the noncomattal bloticounit terminology of Dice (1943) is eaployed in desIgnating the following herpetofaund arees in eastern Tennessee. The primary purpose in proposing these areas is to call attention to the fact that the reptiles and amphiblane are grouped Into recognisably distinct assemblages (Fig. 38).

The Cumberland Plateau (exclusive of the Cumberland Nountains), the Inoxville-Chattanooga Sagment of the Valley, the lower slopes of the Unakas (to 2,500 feet) south of the French Broad River, and all of the Unaka Frovince south of the Hivassee RIver may be designated as the Tranaltion Derpetofaunal District. This district penetrates the nountains along the valleys of the mafor rivers such as the Little Tennessee, the Ittle, and the Hwassee. The tern Transition is selected in recognition of the edalxture in this region of southern, northern, and vestern extraneous forms. The northern boundary of southern forms and the eastern boundary of western forme nearly coinclde with the northern and eastern boundaries of this district. The forests of this district are 


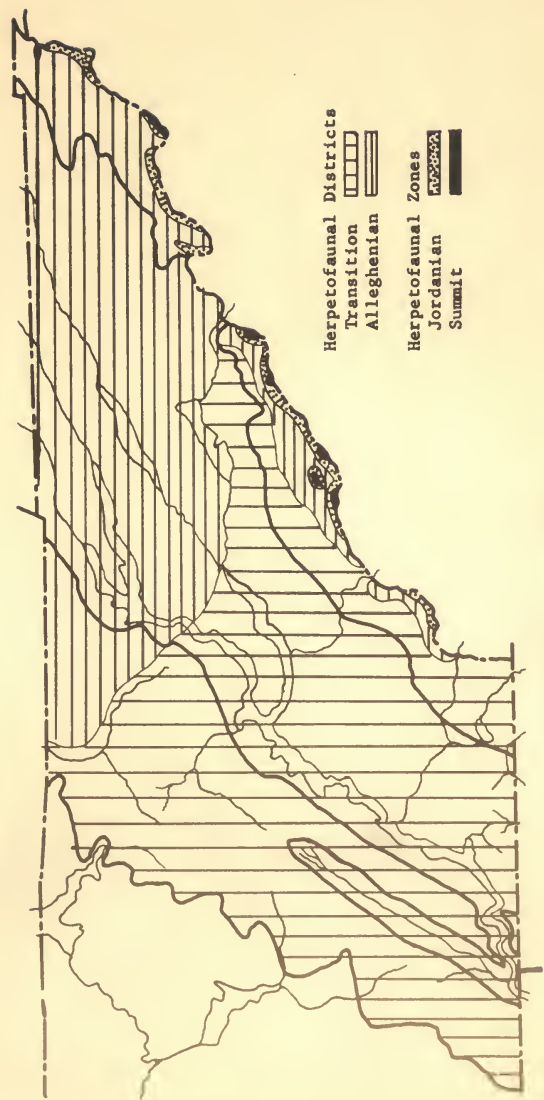

ญ 
characterized by the praponderance of plnes, oaks, and hickorles. PInes may constitute 50 per cent or more of the dominant tree specles. The temperature-aolsture relationships of weather stations in th1s distriet are more nearly 11ke each othor than like thom of stations in areas to the north or at higher elavations to the east.

The Cumberland Mountalas, the Valley north of Knoxville, the Unske Mountains north of the French Broad RIver to an elevation around 3,000 feet, and the slopes of the Unake Mountalns south of the French Broad River below elevations of 2,500 and 3,500 feet ingy be considered as the Alleghenian Herpetofaunsl platrslct. The tera Alleghenian is selected because of the northern extraneous forms. These northern herpetofaunal elements are charactarlatic of the Allegheny plateaus and mountalns to the north of eastorn Tennessee. Negatively, the Alleghenian District 1s distingulohed from the Transition District by having fever southern form and no western forms in the Unakas south of the French Broad River, no southern forms in the Cumberland Mountalns arce, and no southern or western forns north of the French Broad River. Character1stic forast coamunities are mixed mesophyt1c forest in the Cumberland Hountalns and in the ravines and deaper strean valleys of the Valley and Unake sections. On the ridges in the Valley, on the slopes of the Unakas, and in higher parts of the Cumberland Nountains, white oak, red oak, and (formorly) chestnut forests preva11. Plne 1s not a conspleuous trae except on poorer sites. Teaperature-molsture regimes of the weather stations in th1s district are mora nearly like each other than like those fron the Transition District. 
The Unaka Mountalns between elevations of 3,000 to 4,500 feat In the north and betwean 3,500 and 5,000 feet in the south may be deaignated as the Jordanian Herpetofaunal zone. The term Jordanian refers to the salamander Plethodon Jordant, subspecies of which are prevalent in this zone. They may oceur at the higher elevations of the preceding zone, but to my knowledga, this is the only area Inhabited in cormon by all three subepecies in eastern Tannessee. It 18 also in this zone that the so-called "northern hardwoods" forest is encountared (Braun, 1950: 207). Climaticaliy, this zone differs from the praceding gone in 1ts lower wean monthly temperaturas and inereased pracipitation.

The sumalts of the Unake Mountalns, in excess of 4,500 to 5,000 faet, mey be termed the Sumnte Herpetofaunal zone. The tarm Summit is chosen in preferance to Boreal because the lattar term has a definite association with the concept of the Borcal Forest. As discussed previously, the aurait combunities of the Unaka Yountalns ere not conelderad as outliers of the Boreal Foraet. Herpetofaunaliy, this sone is depauperate (Tables 2 and 3). Only one extraneous form (B. 5 . enericanus) and efght endenfe salamanders are known by we to frequent these sumatt areas. Vagatationally, this sone is distinguishad by spruce-flx, flx, and gray beech forests and by grassy or haath balds. Climatically, it 1. distinct in having the coldest temperaturas and maximun precipitat1on.

The Intraneous herpatofaunal elemente ere purposely onitted from the fozegoing discuseion of blotic districts and zones. These elemeats ere of greater significance as "binding specles" (Clements 
and Shelford, 1939: 242). That each of the abova districts and rones 1s but a part of a larger communtty is attested by several features. F1rat, declduous trae characterire the phyelognomy of each of the cl1mex communtt1es, excapt for part of the sumit sone. Horbover, the occurrance of the same dousnant forns in different associations is accepted as Indicating the comnon origin of the various associations (Clements and Shalford, loc. cit.). A poselble exception to this concept way ba the spruce-fir foreets. Sacond, while difforing quallcativaly and quant1tatively, in torns of extraneous and andemic herpetofaunal elenents, the districts and zones are strikingly simflar in terms of intraneous elements. Finaliy, the rangas of many of the intraneous forms nearly coIncide with the extent of the Deciduous Forest Biome, wthin which is Included eastern Tennessee and Its highest wountaln avanits. 


\section{v. SURemarY}

The study area 18 eastern Tennessee from the western excarpment of the Cumberland Plateau castward to the Tenaessee-liorth Carolina state IIne along the sumits of the Unake Bountalns, and from the TennesseeKentucky state IIne on the north to the Tennessee-Georgla state line on the south. The physlographlc provinces, soll types, vegatation, cllmate, and drainage are discussed. Most of these discusslons are summarles from published sources. Th1s information is utillzed in the interpratation of the regional distribution and ecologle associations of the auphlblans and reptiles in esstern Tonnessee.

Basic to the Interpratation of the distribution and ecologic assoclations of the amphiblans and reptiles was the task of conpling a 11at of the herpetofaune of the study axea. Thls was eccomplished by collecting in the field. However, to supplement fleld collections, I have drawn freely from published sources.

Mineteen specles of salamandars (excluding the aubfamily Desmognathinae), 15 specles of amurans, 11 species of turtles, 8 specles of 11zards, and 22 specles of snakes are raported as occurring in eastern Tennesen. Roporting the occurrence of these specles in the study area is based upon critical examination of series of specimens collected durIng the study. The taxconomic allocation of each series 1 s based upon a conparison of the material with descriptions in monographs and references. In severel Instances, the specimens are compared with series of Identified ateriel in the UnIversity of Florida collections. When material from eastern Tannessee differs froe taxononic dascriptions 
and 18 difficult to Identify taxononically, this is emphasized in the eccount of the species to which the asterial is tentetively allocated. Wo attermpt 16 made to redefine or to refine the existing taxononde stetus of the species encountered. Reporting the occurrence of Scephlopus h. holbrook1, Graptegye R. ouechitensis, Coluber c. Eleviventris, Natris s. Rleuralls, pladophis R. punctetus, and klaphe o. Bp1loldes in eastern Tennessee const1tutes extension of the known ranges of these forme. Evidence 18 also presented to Indicate that eastern Tennesse 10 In the sone of Intergredation anong subppecies of 3 selamanders, 2 snurans, 4 turtles, and 6 snakes. Included with the tasonomic discussion of each forn ere renarks concerning the known hor 1zontal and vertical distribution of the various amphiblens and reptiles In eastern Tennessee.

Intraneous, extreneous, and endemic forms are recognized anong the elements of the herpetofauna. Extraneous forms are further characterized as of western, southern, or northern derivetion. These five categorles are based upon the spetial relationghip between the occurrence of the various amphiblane and reptiles in eastern Tennessee and the remalnder of their respective renges as presently defined. There are 52 extranaous forns; 19 with northern affinities, 21 with southern effinities, and 12 with western affinities. Intraneous forms total 30 , and of endenle forms there are 13. Most of the vestern extreneous forms are confined to the Cuaberland Plateau, the southern part of the Velley Rrovince, and the lower alopes of the Unake Nountelns south of the French Broad River. The1r occurrence In eastern Tennessee is 
attributed to factors prevalling during the postglaclal rerothermic perlod. Most of the southern extraneous forms are confined to the southern part of the Valley and to the Iower elopes of the Unaka Mountains south of the French Broad River. Four "Bouthern" forms (2 salanander, 1 11zard, I snake) are practically confined to these lower slopes of the mounta1ns. The apparently anonolous restriction of southern anphibians and raptiles to the mountain province is attributed to the climatic conditione on the lower slopes, especially the high sumer precipitation. The northern extraneous elements are asot mumerous in the Cumberland Mountains, the northern helf of the Valley, and in the Unaka Hountains betwreen elevations from 2,500 to 3,500 feet. Only one northern extraneous form occurs above an elevation of 5,000 feet. Intraneous elemonts occur throughout eastern Tennessee except thet only three (viviparous snakes) occur at the highest elevations around 6,000 feet. Of the endentc species, all but three are confined to the Unaka Kountains.

Differentiation of certain of the endemic salamandars 18 speculated as being the result of the isolation of encestral populations at high elevations during the rerothermic period. The distribution of the endenic turtle . . . troost1 is explatned as the result of separation of encestral populations during the time of maximum Plelstocene glaciatlon.

As a result of this study, division of eastern Tennessee into four herpetofaunal areas 18 proposed. The basis for these proposed areas 18 the vertical and horizontal distribution of the amphibian and 
reptile assemblages. Vegetation and climate are also employed in definIng the areas. These areas are not colncldent with phyalographle boundartee. 


\section{LITERATURR CITED}

Allee, พ. C., A. B. Enerson, C. Park, T. Park, and R. P. Schntdt. 1949. Principles of Animal Bcology. Phlladelphia: W. B. Saunders Company. xi1f 837.

Allen, Joel A. 1892. The geographleal distribution of North Anerican manns 1s. Bul1. Amer. Mus. Mat. Bist. 4:149-243.

Ash, B. C11nton, 1945. Sone reptiles from southeastern Tennessee and north Georg1e. Jour. Ienn. Acad. Se1. 20:261-265.

Ashley, George H. 1930. Age of the Appalechlan peneplains. Bull. Ceol. Soc. Amer. 41:695-700.

Auffenbers, Walter. 1953. A reconsideration of the racer, Coluber constrictor, in eastern United States. Tulane studies In 2001. 2:89-155.

M8. 1957. A study of the fose11 snakes of F1or1da. Unpub11shed dissertation, Unfversity of Florlds.

B1111ngs, W. D., and A. F. Mark. 1957. Factors 1nvolved in the persistence of montane treeless balds. Bcol. 38:140-142.

B1shop, Sherann C. 1947. Handbook of Salamanders. Ithaca: Constock Publiahing Company, xiv 555 .

Blanchard, Frank N. 1921. A rev1sion of the king snakes: gemus Lampropelt1s. U. S. Mat. Mus. Bul1. 114. 111/260.

1925. The forms of Carphophla. Papers Mch. Acad, Sc1. Arts

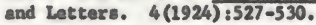

1942. The ring-neck snakes, gemus Dladoph1s. Bull. Chlcago Acad. Sc1. 7:4-144.

Braun, I. Lucy. 1950. Dec1duous Forests of Eastern North Amer1ca. Ph1ledelphia: Bleikiston Company. xiv\$596.

1951. Plant distribution in relation to the glaciel boundary. Oh1o Jour. Se1. 51:139-146.

Brimley, C. S. 1944. Amphiblans and Rept1les of North Carolina. Elon College: Caroline Blological Supply Company. 63.

Brown, D. M. 1953. Contfer traneplants to a grasey beld on Roan Hounteln. Bcol. 34:614-617. 
Burger, W. Leslle. 1952. A neglected subspaclas of the turtla, Preuders seripta. Jour. Tenn. Acad. Sc1. 27:75-89.

Burt, Charles B. 1931. A study of the telld 11zards of the genus Cnemidophorus with spacial raference to thelr phylogenetic Relationships. 0. 8. Mat. Mus. Bul1. 154. vilf286.

Caln, Stanlay, A. 1944. Toundations of Plant Geography. New York: Harper and Brothare. xiv $\$ 556$.

Cagle, Ired R. 1953. Two new subspecies of Graptenys Rseudoseographica. Occ. Papers Mus. 2001., Univerelty of Michigan. 110. $546: 1-17$.

Carx, Archle. 1952. Handbook of Turtles. Ithaca: Comstock Publishing Company. axv $\$ 542$.

and Colemen J. Coln. 1955. Gulde to the Reptilas, Amphiblans, and Fresh-water Fishes of Florida. Galnesville: University of Florida Frass. Ix\&241.

Cley, - ML111am X. 1938. A synopsis of the North Anarican water snakes of the genus Iatrix. Copela No. 4:173-182.

Clements, Freder1c E., and V1ctor E. Shelford. 1939. B10-ecology. New York: John Wiley and Sons. v1/425.

Conant, Roger. 1939. The Rapt1les of Oh10. Notre Dame: The Univerelty Press. 200.

1943. The ailk snakes of the Atlantic Coastal Plain. Froc. New Bngland 2001. Soc. 22:3-24.

1946. Intergradation among ring-necked snakas from southern New Jersey and the Del-Har-Va pentneula. Bull. Chlcago Acad. Se1. $7: 473-482$.

1951. Revialonary addenda: the raptiles of Ohio. Amar. Mdd. Nat. Special reprint:200-284.

et al. 1956. Comon names for North American amphiblans and rept1les. Cope1a No. 3:172-185.

Crenshew, John W. US. 1955. The ecologleal geography of the Paadengs floridans complex in the southastern statas. Unpublished dissertation, University of plorida.

Daubenalra, R. 1956. Climate as a detarminant of vagetation distribution in aastern Washington and northern Idaho. Bcol. Monogr. $26: 13-154$. 
Davidson, Donald. 1946. The Tennessee. Vol. I: The Old River, Prontier to 8ecess1on. New York: Rinehart and Company. x/342.

Deavey, Bdward 8. 1949. Blogeography of the Plelotocene.' Bull. Gaol. Soc. America. 60:1315-1416.

Dendy, Jack 8., and Rlchard H. 8troud. 1949. The dominating Influence of Fontana Reservoir on teraperature and dissolved oxygen in the Little Tennessee River end its Impoundments. Jour. Tenn. Acad. sc1. 24:41-51.

Dice, Lee R. 1943. The Blotic Rrovinces of North Amer1ce. Ann Arbor: University of Mlchigen Press. vi11478.

Dowling, Herndon 6. 1951. A proposed standard system of counting ventrals in snakes. Britioh Jour. Herpetology. 1.

US. 1951. A taxonowic study of the Amer1can zepresentatives of the genus Blaphe Fitsinger, with particular ettention to the forme occurring in Mextco and Central Amarica. Unpublishad dissertation, Bniversity of Michigan.

Dunn, Rumet R. 1926. The Salamanders of the Pamily Plethodontidae. Northampton: 8nith College. vilif441.

Fenneman, Nev1n A. 1938. Physlography of Eastern United states. New York: HcGraw-ill11 Book Company. x111/691.

Ganier, Albert F. 1933. A Distributional List of the BIrds of Tennessee. Nashville: Tennasece Ornithological Soclety. 62.

Gantry, Glenn. 1955. An annoteted check 11st of the auph1bians and rept1les of Tennessee. Jour. Tenn. Acad, Sc1. 30:168-251.

Gloyd, Howard $\mathrm{K}$. 1940. The rettlesnakes, genere Blstrurus and Crote1us. Chlcago Acad. Sc1. Spec1el Publ. No. 4. v11/266.

and Roger Conant. 1943. A synopels of the Amarican forms of Agks strodon (copperheads and moceasins). Bull. Chicago Acad. se1. $7: 147-170$.

Cordon, Robert E. 1952. A contribution to the 11fe hlatory and ecolo$8 \mathrm{y}$ of the plethodont1d salamander Ane1des seneus (Cope and Packard). Anor. Midl. Nat. 47:666-701.

Grobman, Arnold B. 1941. A contribution to the knouledge of variation In Opheodrys vernalis (Harlan), wh a description of a new oubspec1es. Misc. Pub1. Mus. Zool., University of Mch1gan. No. $50: 7-38$. 
Grobman, Arnold B. 1943. Notes on salamanders, with a description of a new species of Gryptobranchus. Oec. Papers Mus. Zool., Daiversity of Luchigan. Mo. 470:12.

Halrston, Nelson C., and C11fford B. Pope. 1948. Geographle variation and speciation in Appalachian salamanders (Plethodon tordani group). Evol, 2:266-278.

Haral1ton, Wh. J. 1943. The Marmals of Eastern Bnited States. Ithacs: Comstock Publishing Conpany. 432.

Hesse, R., W. C. Allee, and R. R. Schnidt. 1949. Bcological Animsl Ceography. Sacond Idition. New York: John w1ley and Sons. xi11/715.

Highton, Richard. US. 1956. The relationships of the salamanders of the genus Plethodon. Unpublished disertation, University of Florida.

Johnson, Richard M. 1953. A contribution on the 11fe history of the 11zard Scincella iaterale (Sey). Tulane Studies In Zool. $1: 11-27$.

1954. The painted turtle, Chrysengs plete plete, in castern Tennessee. Copela 110. 4:298-299.

Kendeigh, s. C. 1954. History and evaluation of varlous concepts of plant and animal communitles in Borth Amerlea. Bcol. $35: 152-171$.

King, P. B., and Arthur Stuplca. 1950. The Great Smoky Mountains--their geology and natural history. Sc1. Mon. 72:31-43.

king, w1111a. 1939. A survey of the hexpetology of the Great Smoky Mountalns Mational Park. Amex. Midl. Nat. 21:531-582.

Luabke, B. H., S. พ. Atkins, C. B. Allred, and พ. J. Koth, 1939. Types of farming in Tennessee. Unlversity of Tennessee Agr. Exp. Ste. Bul1. 169:3-94.

Martoff, Bernaxd, and Robert h. Humphries. 1955. Observations on some Caorgla amphibians and reptiles. Copela No. 3:245-248.

McConkey, Edwin H. 1954. A systematic study of the Forth Amarican 11zards of the genus Ophisaurus. Anor. Md1. Mat. 51:133-171.

MeCrady, Edvard. 1954. A new apecles of Grfnophilus (Plethodontidea) from Iennesses Caves. Copela klo. 3:200-206.

Mecham, John S. MS. Geographle variation in the green frog, Rana clamItans Letrielle. Unpublished dissertation, University of Florida. 
Merrian, C. H. 1892. The geographical distribution of I1fe in North Amarics. Proc. Blol. Soc. Washington. 7:1-64.

Message from the President of the Untted states. 1902. A Report of the Secretary of Agriculture in Relation to the Forest, Rivers, and Hountains of the Southern Appalachian Region. Senate Doc. No. 84. 221.

Mittleman, H. B. 1946. Notes on some Tennessee salamnders of the gemus Pseudotriton. Nat. Hist. Mse. Mo. 4:1-2.

1949. American Caudata,VI. The races of Euryces blelineata. Proc. B1ol. Soc. Washington, 62:89-96.

Hoore, Raymond C. 1949. Introduction to Mistorleal Geology. New York: McGraw-H111 Book Company. Ix\&582.

Pope, Cl1fford H. 1946. Turtles of the Untted States. Nev York: Alfred A. Fnopf. xvili\& 343 .

Rhoads, Samuel W. 1895. Contributions to the voology of Tenneseec. Nol 1, reptiles and amphtbians. Proc. Acad. Nat. Sc1. Philadelphia. 47:376-407.

RLdley, H. N. 1925. Endenic plants. Jour. Bot. 63:182-183.

Rodgers, John. 1953. Geologle Map of Last Tennessee whth Bxplenatory Text. Nashville: Tenneseee Dept. Consexvation. vif168.

luthven, Alexander G. 1908. Varlations and genetic relationships of the garter-snakes. 0. 8. Nat. Nus. Bul1. 61: xilf198.

Safford, James M., and J. B. Killebrew. 1900. The Elements of the Geology of Tennessee. Mashville: Foster and Webb, Publiahers. v11/264.

Schaldt, Karl P. 1953. A Checklist of North American Anphlbians and Rept1les. Sixth Idition. Chicago: University of Chicago Fress. v11\&280.

and D. Dulght Davis. 1941. Fleld Book of Snakes. New York: G. P. Putnan;s Sons. x111/365.

Schwartz, Albert. 1953. A new subspecies of crowned snake (Tant111a coronata) from the Southern Appalachian Mountains. Herpetolo81ea. 9:153-157.

Shanks, Boyal B. 1954. Climates of the Great 8moly Hountains. Bcol. $35: 354-360$. 
Shanks, Royal E. 1956. Altitudinal and weroclimatie relationships of so11 temperatures under natural vegetat1on. Bcol. 37:1-7.

Sntth, Albert G. 1948. Intergradation In worn snakes (Carphoph1s) froa Kentucky. Mat. H1st. Mise. Mo. 18:17-19.

Salth, Hobart M. 1946. Handbook of Lizards. Ithace: Constock PubliahIng Company. $\operatorname{xxd} / 557$.

and Bryan P. Class. 1947. A new wusk turtle from southeastern states. Jour. Washingtou Acad. Sc1. 37:22-34.

Salth, PhIlip W., and Dorothy M. Salth. 1952. The relationshtps of chorus frogs, Peeudacris nIerite feriarua and Peeudacris n. triser1ata. Amer. Md1. Nat. 48:65-180.

and Hobart M. Selth. 1952. Goographie variation in the 11zard Buneces anthracinus. University of Kansas 8cl. Bull.

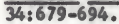

Society of American Foresters. 1954. Forest Cover Types of worth Amarica (exclusive of Mexico). Washington: Soclety of Aserican Foresters. 11f67.

8tu11, O11ve F. 1940. Variations and relationships in the snakes of the genus Pltuophis. v. S. Nat. Nus. Bu11. 175. vif225.

Tennessee Valley Author1ty. 1941. Areas Characterised by Princ1pal Forest Types in the Tonnessee Valley. Knoxville. (map)

Thomes, Bdward 8. 1951. Distribution of Ohlo antmels. Ohio Jour. Sc1. 51:153-167.

Thornthwatte, C. Warren. 1948. An approech to a rational claselfication of climate. Geogr. Rev. 38:55-94.

Tinkle, Donald W., and Iobert G. Hebb. 1955. A new specles of Sternotherus with a discussion of the sternotherus caringtus complex (Chelonia, Kinosternidae). Tulane Studies in 2001. $3: 53-67$.

Vlosca, Percy. 1937. A tentative revision of the genus Necturus with deseriptions of three new species from the southern Gulf drainage. Copela No. 2:120-138.

Walker, Charles F. 1946. The anphlblans of Ohlo. Part I. The frogs and toads (Order Sallentla). Ohlo state tus. Sel. Bull. I:5-109. 
We11s, B. พ. 1956. Origin of Southern Appalachian graes balds. Icol. $37: 56$.

White, Charles I. 1904. The Appalachian River verous a Tertiary trengAppalachlan River in eastern Temneesee. Jour. Geol. 12:34-39.

Whittaker, R. B. 1956. Vegetation of the Great Snoky Mountalns. Ecol. Monogr. 26:1-80.

Willlams, Samuel C. 1937. Davn of Tenneseee Valley and Tennesece History. Johnson C1ty: Watauge Prese. xi/495.

Witseh1, Inil. 1953. The Cherokee frog, Rana oylvatica cheroktana non. nov., of the Appalachian Mountain reg10n. Proc. Iowa Aced. Se1. 60:764-769.

Wolfe, John 1. . 1951. The possible role of aleroclimate. Ohlo Jour. Sc1. 51:134-138.

Wright, Albert H., and Anna A. Wright. 1949. Handbook of Froge and Toads. Ithacs: Comstock Publiohing Company. xilf640.

1957. Handbook of snakes. Vols. I and II. Ibid. xvilif1105.

Yearbook of Agriculture: 1938. Sol1s and Man. Washington: Covernment Printing office. xilf1232.

1941. Climate and Man. Ibld. xilf1248.

Zeuner, P. B. 1950. Dating the Past. London: Metheun, zv111/474. 


\section{BIOGRAPHICAL SKRTCH}

The author was born In Carey, Ohio, on Karch 4, 1924. FollowIng graduation from high school in 1942, he was Inductad into the Aruy of the United Statas and served three years as a surglcal techniclan in the Medical Department.

Upon separation from the service, he attanded Ohio stata Univeralty. He graduated from this Institution in 1949 with the degree of Bachelor of Sclence In W1Idlife Management. From Fabruary, 1950, unt11 August, 1951, he was a graduate student in the Department of Zoology, Tulane University. Hare he held a graduate assistantehip and served as an assiatant in the soology laboratorles, curator of the Rasearch Collactions, and curator of amphiblans and rept1les in the Audubon Park 200. He was graduated from Tulane Univeralty in 1952 with the degree of Mater of Sclence in Zoology.

From September, 1951, to date he hes been Head of the Department of B10logy, Tennessee Wesleyan Collage. During the acadenic year 195354 he was grantad leave-of-absance to begin studies for tha degree of Doctor of Philosophy in the Department of Blology, Univeralty of Florida.

The author 18 a nember of Gamm S1gma Delta, Ph1 S1gma, the Soclety of S1gma X1, the American Soc1ety of Ichthyologists and Herpetolog1ats, the Bcological Soc1ety of Amar1ca, the Herpetologist's Lague, and the social fraternity Bata Theta P1. He is maxriad and with his wifa has two daughters. 
This dissertation vas prepered under the direction of the cocheirmen of the candidate's supervisory connit tee and hes been approved by $a 11$ members of that committee. It was submitted to the Dean of the College of Arts and Sclences and to the Graduate Council, and was approved es partiel fulfillment of the requirements for the degree of Doctor of Philosophy.

June 9, 1958

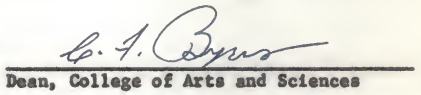

Dean, Graduate School

SURERVISORY COAITIEE:

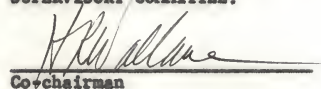

Hrabie Cars

Grues B Folues

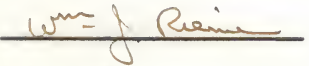

sea Elwars 